\title{
Geohydrology of Osceola County, Florida
}

\section{By George R. Schiner}

U.S. GEOLOGICAL SURVEY

Water-Resources Investigations Report 92-4076

Prepared in cooperation with

SOUTH FLORIDA WATER MANAGEMENT DISTRICT

ST. JOHNS RIVER WATER MANAGEMENT DISTRICT 


\title{
U.S. DEPARTMENT OF THE INTERIOR BRUCE BABBITT, Secretary
}

\author{
U.S. GEOLOGICAL SURVEY
}

Dallas L. Peck, Director

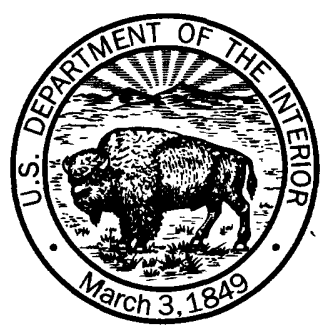

For additional information write to:

District Chief

U.S. Geological Survey

Suite 3015

227 N. Bronough Street

Tallahassee, FL 32301
Copies of this report can be purchased from:

U.S. Geological Survey

Books and Open-File Reports Section Federal Center

Box 25425

Denver, CO 80225 


\title{
CONTENTS
}

\author{
Abstract 1 \\ Introduction 2 \\ Purpose and scope 2 \\ Previous studies $\mathbf{2}$ \\ Study approach 4 \\ Acknowledgments 4 \\ Well-numbering systems \\ Landforms, drainage, and land use 4 \\ Climate 7 \\ General geohydrology of the ground-water system 7 \\ Geologic framework 9 \\ Hydrogeologic framework 10 \\ Ground-water occurrence and movement 16 \\ Water quality 17 \\ Geohydrology of the surficial aquifer system $\mathbf{1 8}$ \\ Hydraulic properties $\mathbf{1 8}$ \\ Water levels 22 \\ Recharge and discharge 22 \\ Water quality $\mathbf{2 2}$ \\ Availability of water $\mathbf{2 4}$ \\ Geohydrology of the intermediate confining unit $\mathbf{2 5}$ \\ Geohydrology of the Floridan aquifer system $\mathbf{2 8}$ \\ Hydraulic properties $\mathbf{3 0}$ \\ Description of wells that tap the Floridan aquifer system $\mathbf{3 8}$ \\ Potentiometric surface 39 \\ Water levels 39 \\ Recharge and discharge 44 \\ Water quality $\mathbf{4 5}$ \\ Areal distribution of chloride concentration 49 \\ Variations of chloride concentration in wells $\mathbf{5 1}$ \\ Trends in chloride concentrations $\mathbf{5 2}$ \\ Availability of water $\mathbf{5 3}$ \\ Water use $\mathbf{5 5}$ \\ Summary and conclusions $\mathbf{5 7}$ \\ Selected references $\mathbf{5 9}$ \\ Appendix I. Well data in files of the U.S. Geological Survey used for data analysis 63 \\ Appendix II. Well data in files of the Florida Geological Survey used for data analysis 67
}

Figure

1-4. Maps showing:

1. Osceola County study area $\mathbf{3}$

2. Location of wells used for data analysis 5

3. Pleistocene terraces in Osceola County 6

4. Drainage features of Osceola County 8

5. Graph showing annual and monthly rainfall at Kissimmee, 1930-88, and annual rainfall at Fort Drum, 1957-86 9

6. Graph showing gamma-ray log of well 113 showing geologic formations and hydrologic units 11

7. Map showing location of lines of hydrogeologic section

12 
8-10. Hydrogeologic sections:

8. $A-A^{\prime}$ and $B-B^{\prime}$ showing geologic and hydrologic units $\mathbf{1 3}$

9. $C-C^{\prime}$ and $D^{-D^{\prime}}$ showing geologic and hydrologic units 14

10. E-E' and F-F' showing geologic and hydrologic units 15

11. Map showing potentiometric surface, May 1981, and areas of natural recharge and discharge of the Upper Floridan aquifer 16

12-14. Graphs showing:

12. Classification of salinity and limiting concentrations of chloride recommended for plants, animals, public supply, and industrial use 17

13. Relation between chloride concentration and specific conductance $\mathbf{1 8}$

14. Relation between specific conductance and dissolved-solids concentration, and the classification of salinity of water 19

15. Map showing thickness of the surficial aquifer system $\mathbf{2 0}$

16. Map showing location of test sites and wells in the surficial aquifer system and intermediate confining unit for which hydrographs are shown 21

17-22. Hydrographs showing:

17. Water level in well 21 , and annual rainfall at Kissimmee, 1949-87 23

18. Water level in well 31, and annual rainfall at Kissimmee, 1974-87 24

19. Water level in well 96, and annual rainfall at Kissimmee, 1950-87 25

20. Water level in well 132, and annual rainfall at Kissimmee, 1948-87 26

21. Water level in well 172, and annual rainfall at Kissimmee, 1950-87 27

22. Water levels in wells 132 and 169 , and annual rainfall at Kissimmee, 1973-87 28

23. Trilinear diagram showing major dissolved-constituent ratios in water from wells completed in the surficial aquifer system 29

24. Map showing thickness of the intermediate confining unit (Hawthorn Formation) 31

25. Hydrograph showing water level in well 37, and annual rainfall at Kissimmee, 1974-87 32

26-32. Maps showing:

26. Thickness of the Floridan aquifer system $\mathbf{3 3}$

27. Altitude of the top of the Floridan aquifer system $\mathbf{3 4}$

28. Altitude of the base of the Floridan aquifer system $\mathbf{3 5}$

29. Specific capacity of wells completed in the Floridan aquifer system and location of aquifer test sites $\mathbf{3 7}$

30. Potentiometric surface of the Upper Floridan aquifer, May $1981 \quad 40$

31. Potentiometric surface of the Upper Floridan aquifer, May $1987 \quad 41$

32. Location of wells in the Floridan aquifer system for which hydrographs are shown $\mathbf{4 2}$

33-35. Hydrographs showing:

33. Water levels in six wells that monitor the potentiometric surface of the Upper Floridan aquifer, and monthly rainfall at Kissimmee, 1976-88 43

34. Water level in well 186 in an area affected by pumping, and annual rainfall at Kissimmee, 1972-88 44

35. Daily water level in well 113 , and monthly rainfall at Kissimmee, 1987-89 45

36. Map showing decline in the potentiometric surface of the Upper Floridan aquifer from predevelopment conditions to May 198746

37. Trilinear diagram showing major dissolved-constituent ratios in water from wells completed in the Floridan aquifer system $\mathbf{4 7}$

38. Graph showing distribution of major constituent concentrations in water from wells completed in the Floridan aquifer system 
39. Map showing chloride concentrations in water from wells that tap the Upper Floridan aquifer $\mathbf{5 0}$

40. Sketch showing hypothetical paths of ground-water movement in wells that penetrate the Floridan aquifer system $\mathbf{5 2}$

41. Graph showing chloride concentrations in water from well 197, 1960-88 53

42. Map showing most favorable areas for future development of large water supplies from the Upper Floridan aquifer $\mathbf{5 4}$

43. Graph showing cumulative water use in Osceola County 56

44. Graph showing annual pumpage by the city of Kissimmee, 1972-88, and the city of St. Cloud, 1977-88 57

Table

1. Water-bearing characteristics and descriptions of the geologic units in Osceola County 10

2. Representative analyses and ranges in concentrations of constituents in water from wells completed in the surficial aquifer system $\mathbf{3 0}$

3. Specific-capacity test data for selected wells that tap the Floridan aquifer system 38

4. Summary of selected properties, major constituent concentrations, nitrogen species concentrations, and phosphorus concentrations in water from wells completed in the Floridan aquifer system $\mathbf{4 8}$

5. Average daily water use in Osceola County $\mathbf{5 5}$ 
Conversion Factors, Vertical Datum, and Abbreviations

\begin{tabular}{|c|c|c|}
\hline Multiply & By & To obtain \\
\hline \multicolumn{3}{|l|}{ Length } \\
\hline inch (in.) & 25.4 & millimeter \\
\hline foot $(\mathrm{ft})$ & 0.3048 & meter \\
\hline mile (mi) & 1.609 & kilometer \\
\hline \multicolumn{3}{|l|}{ Area } \\
\hline acre & 0.4047 & hectare \\
\hline square mile $\left(\mathrm{mi}^{2}\right)$ & 2.590 & square kilometer \\
\hline \multicolumn{3}{|l|}{ Volume } \\
\hline million gallons (Mgal) & 3,785 & cubic meter \\
\hline \multicolumn{3}{|l|}{ Flow } \\
\hline gallon per minute (gal/min) & 0.06309 & liter per second \\
\hline million gallons per day $(\mathrm{Mgal} / \mathrm{d})$ & 0.04381 & cubic meter per second \\
\hline inch per year (in/yr) & 25.4 & millimeter per year \\
\hline \multicolumn{3}{|l|}{ Transmissivity } \\
\hline foot squared per day $\left(\mathrm{ft}^{2} / \mathrm{d}\right)$ & 0.0929 & meter squared per day \\
\hline \multicolumn{3}{|l|}{ Hydraulic conductivity } \\
\hline foot per day $(\mathrm{ft} / \mathrm{d})$ & 0.3048 & meter per day \\
\hline \multicolumn{3}{|l|}{ Specific capacity } \\
\hline $\begin{array}{l}\text { gallon per minute per foot } \\
(\mathrm{gal} / \mathrm{min}) / \mathrm{ft})\end{array}$ & 0.207 & liter per second per meter \\
\hline
\end{tabular}

Equations for temperature conversion between degrees Celsius $\left({ }^{\circ} \mathrm{C}\right)$ and degrees Fahrenheit $\left({ }^{\circ} \mathrm{F}\right): \quad{ }^{\circ} \mathrm{C}=5 / 9\left({ }^{\circ} \mathrm{F}-32\right), \quad{ }^{\circ} \mathrm{F}=\left(9 / 5 \times{ }^{\circ} \mathrm{C}\right)+32$

Sea level: In this report "sea level" refers to the National Geodetic Vertical Datum of 1929 (NGVD of 1929)--a geodetic datum dervied from a general adjustment of the first-order level nets of the United States and Canada, formerly called Sea Level Datum of 1929.

Altitude, as used in this report, refers to distance above or below sea level.

Transmissivity: The standard unit for transmissivity is cubic foot per day per square foot times foot of aquifer thickness $\left[\left(\mathrm{ft}^{3} / \mathrm{d}\right) / \mathrm{ft}^{2}\right] \mathrm{ft}$. In this report, the mathematically reduced form, foot squared per day $\left(\mathrm{ft}^{2} / \mathrm{d}\right)$, is used for convenience.

\section{Additional abbreviations}

$(\mu \mathrm{g} / \mathrm{L}) \quad$ micrograms per liter

$(\mu \mathrm{S} / \mathrm{cm}) \quad$ microsiemens per centimeter at $25^{\circ} \mathrm{C}$

$(\mathrm{mg} / \mathrm{L}) \quad$ milligrams per liter 


\title{
Geohydrology of Osceola County, Florida
}

\author{
By George R. Schiner
}

\section{ABSTRACT}

The Floridan aquifer system is the most important source of water in Osceola County, supplying about 90 percent of all ground water used. The Floridan aquifer system beneath Osceola County consists of carbonate rocks of Paleocene to Eocene age that are about 2,400 to 2,900 feet thick. Hydraulically, it is subdivided on the basis of permeability into the Upper Floridan aquifer (about 300-350 feet thick), the middle semiconfining unit (about 450-700 feet thick), and the Lower Floridan aquifer (about 1,400-2,100 feet thick). An overlying surficial aquifer system supplies most of the remainder of the ground water used in the county. The surficial aquifer system consists mostly of unconsolidated deposits of Pleistocene and Holocene age that range in thickness from about 30 to 270 feet. The surficial and Floridan aquifer systems are separated by a 40- to 300-foot-thick, low-permeability unit of Miocene age known as the intermediate confining unit.

Hydraulic properties of the Floridan aquifer system vary widely within Osceola County. Transmissivities of the Upper Floridan aquifer-estimated from computer simulation-range from about 65,000 to 250,000 cubic feet per day per square foot times foot of aquifer thickness $\left(\left[\left(\mathrm{ft}^{3} / \mathrm{d}\right) / \mathrm{ft}^{2}\right] \mathrm{ft}\right)$ in most of Osceola County. In the northwestern part of the county, transmissivities decline to a range of 6,500 to 65,000 feet $\left(\left[\left(\mathrm{ft}^{3} / \mathrm{d}\right) / \mathrm{ft}^{2}\right] \mathrm{ft}\right)$. Model simulations for the Lower Floridan aquifer indicate a transmissivity of 6,500 to $60,000\left(\left[\left(\mathrm{ft}^{3} / \mathrm{d}\right) / \mathrm{ft}^{2}\right] \mathrm{ft}\right)$. A storage coefficient of about $1 \times 10^{-4}$ to $1 \times 10^{-5}$ is estimated for the Upper Floridan aquifer. Specific capacities of 27 wells in the Floridan aquifer system range from 5 to 510 gallons per minute per foot of drawdown with a median of 57 gallons per minute per foot of drawdown. Wells that tap the Floridan aquifer system generally yield at least several hundred gallons per minute. Deep, large-diameter public supply and irrigation wells yield several thousand gallons per minute.

The regional ground-water movement in the Upper Floridan aquifer is eastward from recharge areas in the Lake Wales Ridge area in Polk County. Water levels have declined about 7 to 15 feet from predevelopment time (1930's) to 1987 . The water-level data indicate no significant water-level decline for the period 1979 through 1988.

Water from the Upper Floridan aquifer in most of the county is hard, has a dissolved-solids concentration of less than 500 milligrams per liter, and has a basic $\mathrm{pH}$. In the eastern half of the county, dissolved-solids concentrations generally increase minimally with depth in the Upper Floridan aquifer, increase variably in the middle semiconfining unit, and probably increase rapidly in the Lower Floridan aquifer. Elsewhere, dissolved-solids concentrations remain relatively constant within the Floridan aquifer system.

Chloride concentrations in water from the Upper Floridan aquifer range areally from 4 to 1,100 milligrams per liter. Chloride concentrations are lowest in recharge areas of the Floridan aquifer system in the northwestern corner of the county and highest in the northeastern corner of the county, (250-1,100 milligrams per liter). Analysis of long-term water-quality data indicate that on a countywide basis, the chloride concentration of water from most wells in the Floridan aquifer system has not changed significantly from 1978 to 1988 , and probably not since 1960 .

The hydraulic and water-quality properties of the surficial aquifer system can range widely at different locations depending on the lithology and thickness of the unit. For most of the county transmissivity values probably range from about 1,000 to 2,000 cubic feet per day per square foot times foot of aquifer thickness, and the storage coefficient is estimated to range from 0.05 to 0.2 . Chloride concentrations in water from the surficial aquifer system probably are significantly less than 250 milligrams per liter. Locally, high iron concentration can be a water-quality problem. Well yields range from about 15 to 300 gallons per minute.

Water use in Osceola County has steadily increased since 1970 with a sharp increase between 1980 and 1985 . Total water use was 59.3 million gallons per day in 1985: an increase of nearly 40 million gallons per day from 1970 to 1985 or an increase of nearly 28 million gallons per day (87 percent) from 1980 to 1985 . 
The western half of Osceola County, excluding the northwestern corner, may be a highly favorable area for future ground-water development from the Floridan aquifer system. The major concern relating to future ground-water development is potential degradation of water quality rather than the quantity of water available. The hydrology of the Floridan aquifer system is complex, and considerable variation in yield and water quality may exist among wells in close proximity and of equal depth.

\section{INTRODUCTION}

The population of Osceola County (fig. 1) has grown rapidly and water demands have increased substantially since the 1970's when tourist attractions opened in nearby Orange County. The population of Osceola County in 1970 was about 25,000 , but, by 1987 , the population had increased nearly 300 percent to about 87,000 . The population is projected to reach about 152,000 by the year 2000 , (Purdum and Anderson, 1988, p. 98). With this growth and the increasing influx of tourists that in 1988 numbered 4.6 million, the need for additional water supplies has also grown. Evaluation of water demand and water-supply potential is particularly needed because former selfsupplied rural areas have become urbanized and added to municipal supply systems, agricultural irrigation has increased, new industries (including tourist attractions) have been established, and the exportation of ground water from the county is a possibility.

About 90 percent of all ground water used in Osceola County is obtained from the Floridan aquifer system. With few exceptions, the remainder of the ground water is supplied by the overlying surficial aquifer system. Water quantity is seldom a problem in the highly productive Floridan aquifer system. However, there are some concerns that, locally, heavy withdrawals from the Floridan aquifer might cause saltwater intrusion which could result in freshwater quality degradation. Excessive withdrawals from the surficial aquifer system over a long period could decrease the amount of water available to recharge the Floridan aquifer system and could also lower lake levels and reduce streamflow in the Kissimmee River and St. Johns River basins.

The need to evaluate the present and potential effect of added stress on the ground-water resources of Osceola County and the need for information to enable State and local officials to protect and manage these resources were the primary reasons for this investigation. The study was done by the U.S. Geological Survey in cooperation with the South Florida Water Management District and the St. Johns River Water Management District.

\section{Purpose and Scope}

This report describes the principal water-bearing features and water quality of the surficial and Floridan aquifer systems in Osceola County so that planning, management, and development of the ground-water resources may be facilitated. It contains geographic and geologic information on the ground-water resources of the county, descriptions of hydraulic properties of the aquifers, information on trends in water levels, water-quality information, and data on chloride concentrations in both aquifer systems. The Floridan aquifer system is given the most emphasis in this report because that aquifer system is the most utilized water source.

The report includes data from reports and files of the U.S. Geological Survey, Florida Geological Survey, South Florida Water Management District, St. Johns River Water Management District, and other governmental agencies and private consultants.

\section{Previous Studies}

The ground-water resources of Osceola County were described as part of a countywide reconnaissance-type study by Frazee (1980). Several reports of ground-water resources on a broader scale also include information on Osceola County. Lichtler (1972) appraised the water resources of east-central Florida, which includes Osceola County. More recently, Reese and others (1984), and Shaw and Trost (1984a,b) of the South Florida Water Management District, presented generalized geohydrologic information pertaining to the county in a report on the Kissimmee Planning area. Planert and Aucott (1985) investigated by digital model the water-supply potential of the northern three-quarters of Osceola County together with eastern Orange and southwestern Brevard Counties. That study also included a general description of the geohydrology of the county. Potentiometric surface maps of the Upper Floridan aquifer are available (U.S. Geological Survey, Altamonte Springs office) for annual high (September) and low (May) well water levels for most years since 1973 .

The geohydrology of the Reedy Creek area of northwestern Osceola County was described in reports by Putnam (1975) and German (1986). Hughes and Frazee (1979) described the surface-water features of the county. Reports on lakes were made for Cypress Lake by Gaggiani and McPherson (1978), for Lake Tohopekaliga by Phelps (1982), and for East Lake Tohopekaliga by Schiffer (1986). Goolsby and McPherson (1978) reported on the limnology of Taylor Creek Impoundment, located in the northeastern corner of the county. 


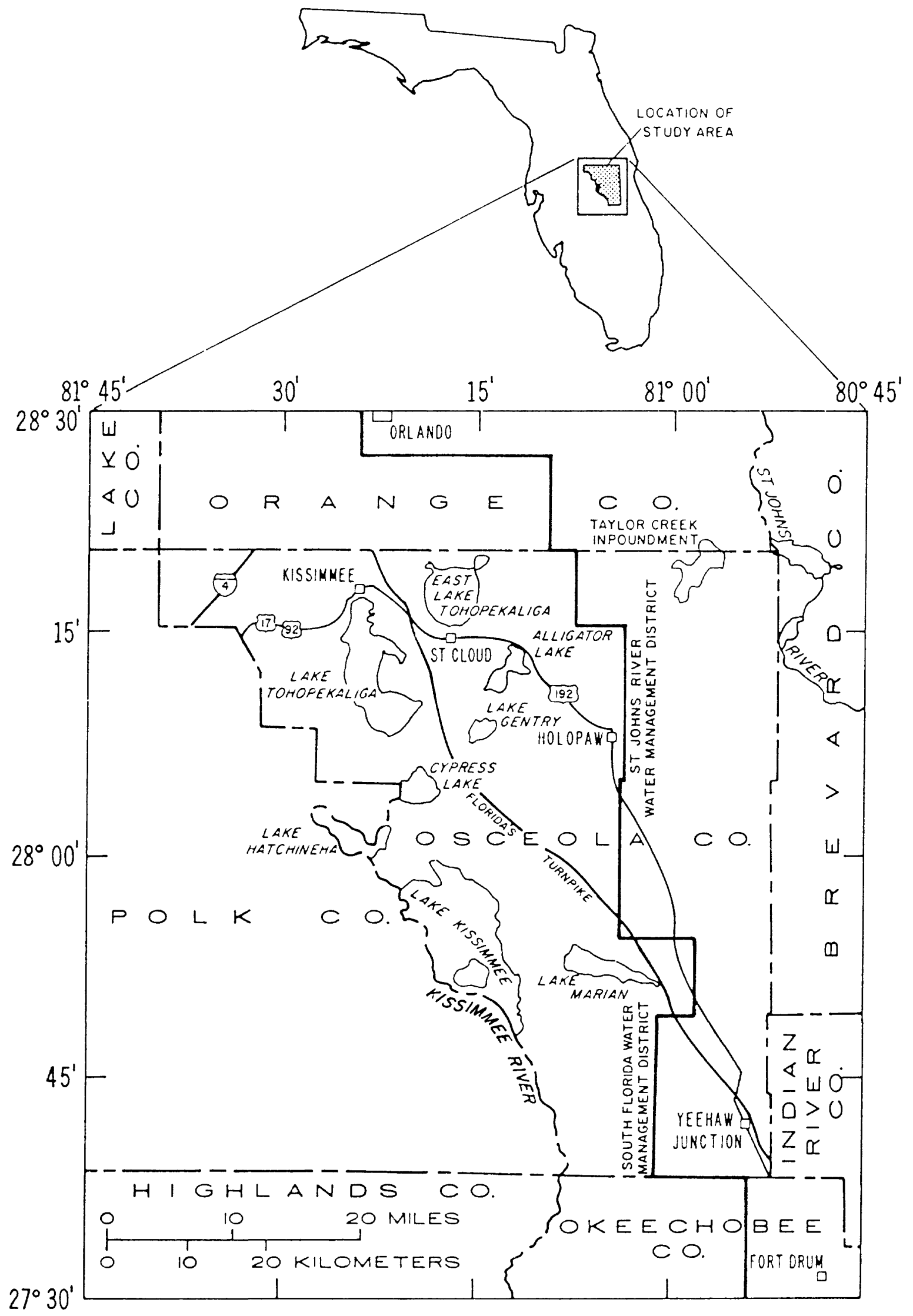

Figure 1. Osceola County study area. 
During 1978 to 1983 , the U.S. Geological Survey made a regional assessment of the Floridan aquifer system (which includes Osceola County) under the U.S. Geological Survey Regional Aquifer Systems Analysis (RASA) program. The results of that study are presented in U.S. Geological Survey Professional Paper 1403.

Logs of numerous wells within Osceola County are contained in the files of the Florida Geological Survey. Descriptions of core tests were given by Johnson (1986).

\section{Study Approach}

Much of the emphasis of this study was to update data collected from 1974 to 1980 . Historical long-term, unpublished water-level records were processed and integrated with published records. Where high chloride concentrations were known to occur, wells sampled in the 1974-80 period were resampled to determine possible trends. Numerous geophysical logs were analyzed for geohydrologic information as were geologic data from well logs obtained from the Florida Geological Survey. Data obtained from the South Florida Water Management District and St. Johns River Water Management District were also analyzed. Legal procedures brought against the South Florida Water Management District by the county during the study period prevented planned test drilling, aquifer testing, establishment of observations wells, and some water-quality sampling.

The locations of wells used for data analysis in this report are shown in figure 2. Data on the physical characteristics of the wells are given in the appendixes.

\section{Acknowledgments}

The author gratefully acknowledges the assistance given by many organizations and individuals during the study and is especially grateful for the cooperation received from the South Florida Water Management District, the St. Johns River Water Management District, and the Florida Geological Survey. Cooperation from the cities of Kissimmee and St. Cloud and the many landowners who permitted access to their wells for data collection is greatly appreciated.

\section{Well-Numbering Systems}

Three numbering systems are used to identify wells in this report: (1) A map-reference well number of up to three digits is used to identify wells and test holes used in illustrations, tables, and in the text; (2) The map-reference well number is cross referenced in appendix I to the U.S.
Geological Survey site identification number, a 15-digit number based on latitude and longitude. The 15-digit number, derived from the latitude and longitude of the station location and a sequence number, is the customary GroundWater Site Identification system (GWSI) of the U.S. Geological Survey, providing a unique number for each station. The first 6 digits denote the degrees, minutes, and seconds of latitude; the next 7 digits denote degrees (using 3 digits), minutes, and seconds of longitude; and the last 2 digits denote a sequential number for the station within the 1 -second grid. Once assigned, a site identification number does not change, even though the latitude and longitude of the location may be revised later. The site-identification number is used in placing and retrieving data from the U.S. Geological Survey's data management system, the National Water Data Storage and Retrieval (WATSTORE) System; (3) Well data from the files of the Florida Geological Survey (appendix II) are identified using their "w" prefix as well as by latitude and longitude.

The St. Johns River Water Management District uses a similar identification system to the U.S. Geological Survey, using latitude and longitude as a primary identifier. For the South Florida Water Management District, the primary identifier is a sequential number assigned to each well as it is added to their network files. The number is preceded by the first two letters of the county in which the well is located and a letter identifying the aquifer system tapped. If the well penetrates the Floridan aquifer system, the two-letter code is followed by an "F"; if the well penetrates the surficial system, an "S" follows. For example, OSF-29 represents the 29th Floridan aquifer system well added to the South Florida Water Management District's network in Osceola County. All "OSF" well data have been placed in the U.S. Geological Survey data storage system.

\section{Landforms, Drainage, and Land Use}

The major land forms in Osceola County evolved during Pleistocene time and consist mostly of marine terraces. Terraces are steplike, extensive flatlands, bordered by scarps and ridges formed by ancient seas that stood at several levels. The shape of the land surface has been modified little since the Pleistocene. The terraces from west to east (fig. 3) are the Coharie, Sunderland, Wicomico, Penholoway, Talbot, and the Pamlico (Healy, 1975). Each successive easterly terrace is lower in altitude and younger in geologic age because of progressively lower sea levels during the Pleistocene. Land-surface altitudes range from $15 \mathrm{ft}$ on the Pamlico Terrace to $205 \mathrm{ft}$ on the Coharie Terrace which caps the Lake Wales Ridge along the northwestern border of the county. According to White (1970, p. 120), the Lake Wales Ridge existed as a residual highland prior to inundation by the Coharie and Sunderland seas. Descriptions of the geologic history and modes of occurrence of 


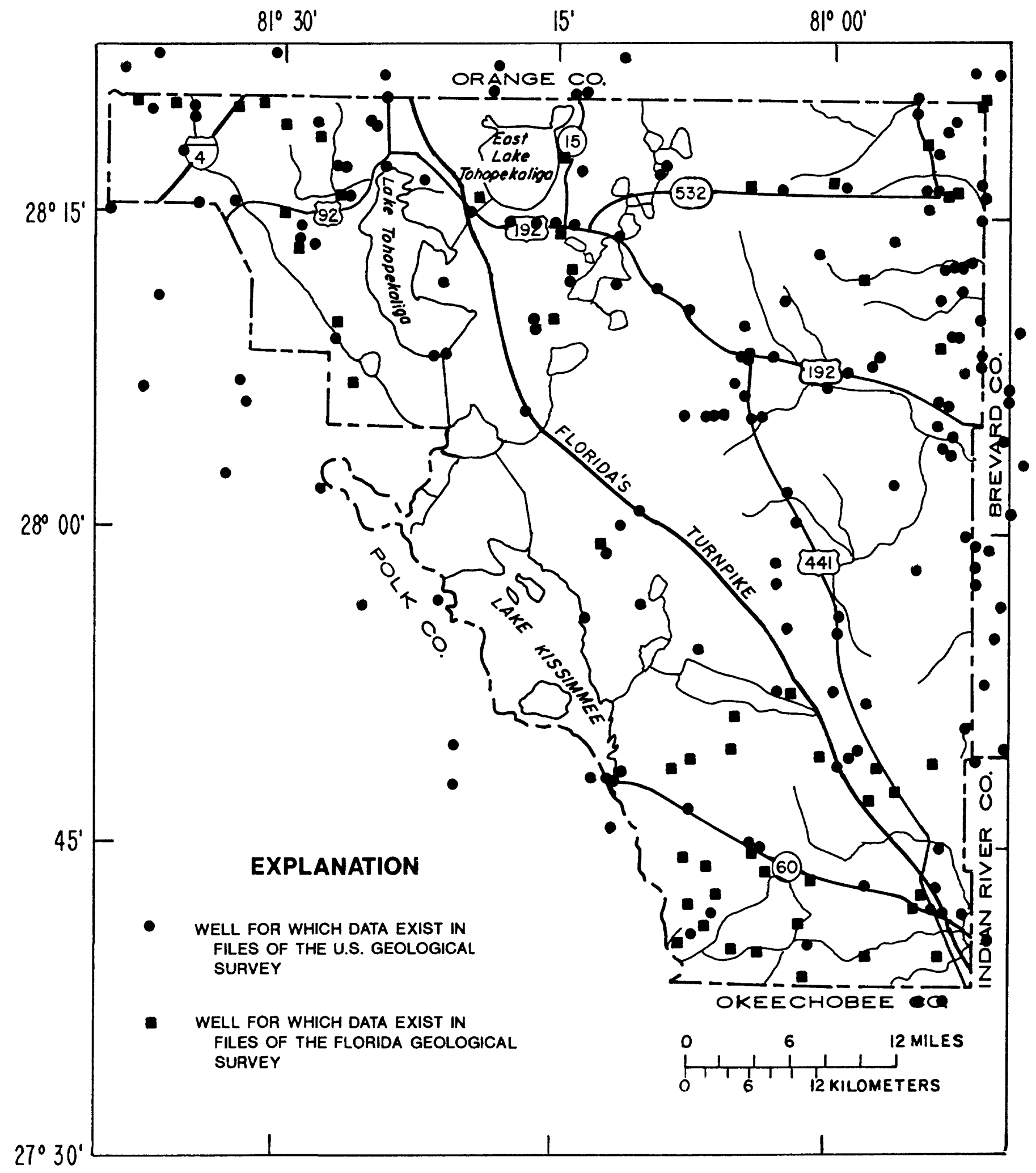

Figure 2. Location of wells used for data analysis. 


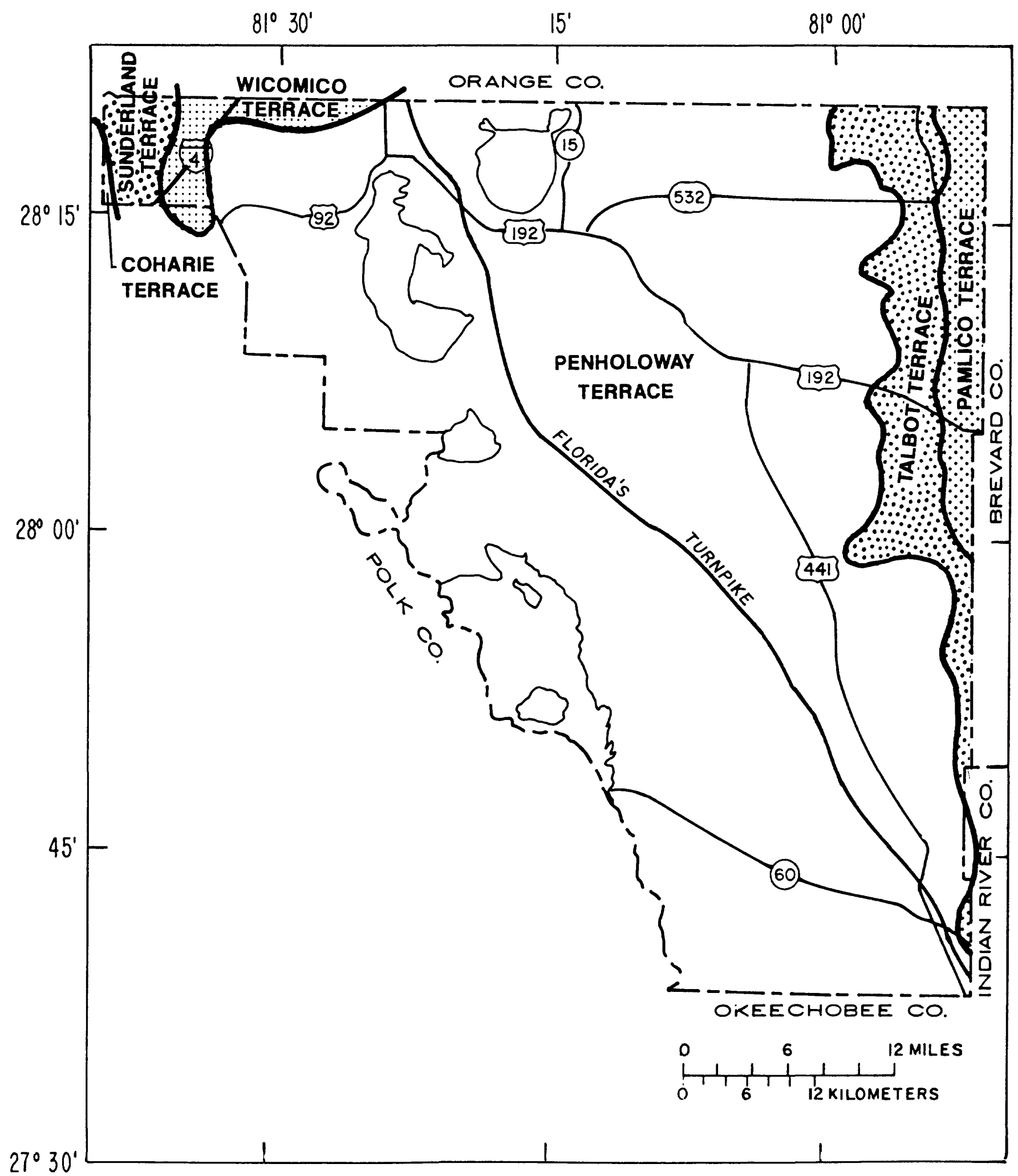

Figure 3. Pleistocene terraces in Osceola County. 
Pleistocene age landforms are given by Cooke $(1939,1945)$, Macneil (1949), Parker, and others (1955), Stringfield (1966), Healy (1975), and White (1970).

Osceola County is in two major drainage basins: the Kissimmee River basin to the west and the St. Johns River basin to the east (fig. 4). The Kissimmee River basin is arbitrarily divided into an upper basin and a lower basin that together cover $933 \mathrm{mi}^{2}$ of the county. The upper basin is bounded on the north by the lakes in the Orlando area and on the south by the outlet of Lake Kissimmee. Major lakes in the upper basin include Gentry, Alligator, East Tohopekaliga, Tohopekaliga, Cypress, Hatchineha, Marian, and Kissimmee (fig. 1). The major headwater streams in the upper basin include Reedy Creek, Shingle Creek, and Boggy Creek (fig. 4).

The lower Kissimmee River basin includes the area tributary to the Kissimmee River from the outlet of Lake Kissimmee to Lake Okeechobee. Below Lake Kissimmee, the Kissimmee River flows through an area of low relief consisting of a marshy flood plain several miles wide, where lakes and well-defined tributary channels are few. The watershed is crisscrossed by many natural sloughs and by less numerous manmade channels that drain to oxbows of the original Kissimmee River.

Prior to 1962 , flooding was a frequent problem in much of the Kissimmee River drainage basin, because land and channel slopes are slight and runoff is slow. During the period 1962-71, major drainage changes to the basin designed to reduce flooding were made by the straightening of natural meandering channels and the construction of canals, levees, and control structures. The flood-control modifications successfully increased the discharge capacity of the river and greatly reduced the flood hazard in the basin (Lamonds, 1975, p. 3).

The eastern part of Osceola County is in the western part of the upper St. Johns River basin, covers $753 \mathrm{mi}^{2}$, and is bounded on the west by the highlands of the Kissimmee River basin. The eastern part of the upper basin in Osceola County is characterized by marshlands associated with streams that drain eastward from the highlands (fig. 4). In downstream order, the streams are: Cow Log Branch of Blue Cypress Creek and Blue Cypress Creek; Bull Creek and Crabgrass Creek tributary to Jane Green Creek; Pennywash Creek, Wolf Creek, Cox Creek, and Taylor Creek (fig. 4). The marshland areas have been considerably modified by dikes, levees, and canals to expedite or control drainage. Taylor Creek Impoundment (fig. 1), part of Jane Green Reservoir, was completed in 1969, and is part of a public works plan to alleviate flood-drought problems. The impoundment drains an area of $52 \mathrm{mi} 2$ and covers part of Taylor Creek and the north and south forks of Taylor Creek (fig. 4).

Osceola County has a total area of $1,507 \mathrm{mi}^{2} ; 1,350 \mathrm{mi}^{2}$ of land and $157 \mathrm{mi}^{2}$ of water. Land use in most of the northwest part of the county is urban. The remainder of the county is mostly farmland. In 1987, total farmland was
$1,140 \mathrm{mi}^{2}$, of which 38 percent was cropland, 34 percent pasture and rangeland, and 28 percent forest (Purdum and Anderson, 1988, p. 98).

\section{Climate}

The climate of Osceola County is classified subtropical humid, characterized by warm, mostly wet summers and mild, generally dry winters. Spring and fall are transitional periods between the major wet and dry seasons. The average annual air temperature is about $72{ }^{\circ} \mathrm{F}$. High afternoon temperatures frequently exceed $90{ }^{\circ} \mathrm{F}$ during the summer months. Most years have a few days of frost or freezing temperatures that generally are more moderate toward the south.

Rainfall can be unevenly distributed areally, seasonally, and annually. Summer rainfall is from local showers and thunderstorms. About 56 percent of the average yearly rainfall occurs in the period June through September. Winter rainfall is generally associated with large, cold, frontal type air masses that move from the northem latitudes southward. These fronts cover large areas, so winter rainfall is more widespread than summer rainfall. Occasional tropical storms or hurricanes may add considerable amounts to the yearly total rainfall.

National Oceanic and Atmospheric Administration records for the weather stations at Kissimmee and Fort Drum (fig. 1) indicate the areally uneven distribution of rainfall within the county. Average annual rainfall for the Kissimmee station (48.4 in.) in northern Osceola County, for the period 1957 through 1984, is about 2.6 in. less than the average annual rainfall at the Fort Drum station (51.0 in.) in Okeechobee County (about $3.5 \mathrm{mi}$ south of the south Osceola County line). The 58-year average annual rainfall at the Kissimmee station for the period 1930 through 1988 is 49.6 in. (fig. 5). Rainfall in the decade 1979 through 1988 at the Kissimmee station (47.5 in.) averaged 2.1 in. less than the long-term annual average. Drought conditions prevailed throughout Florida during parts of 1980 and 1981, causing a 2 -year deficiency of about $23 \mathrm{in}$. from the long-term average at Kissimmee. At the Fort Drum station, the 2-year deficiency (based on the 1957 through 1984 annual average) was about 32 in.

\section{GENERAL GEOHYDROLOGY OF THE GROUND-WATER SYSTEM}

The ground-water system in Osceola County consists of two major water-bearing units; a thin surficial aquifer and a thick high-permeability rock aquifer separated by a thin confining unit. The surficial unit contains the water table and the high-permeability unit is mostly under artesian conditions. The aquifer system is everywhere underlain by a confining unit of low-permeability rocks (Miller, 1986, p. 840). 


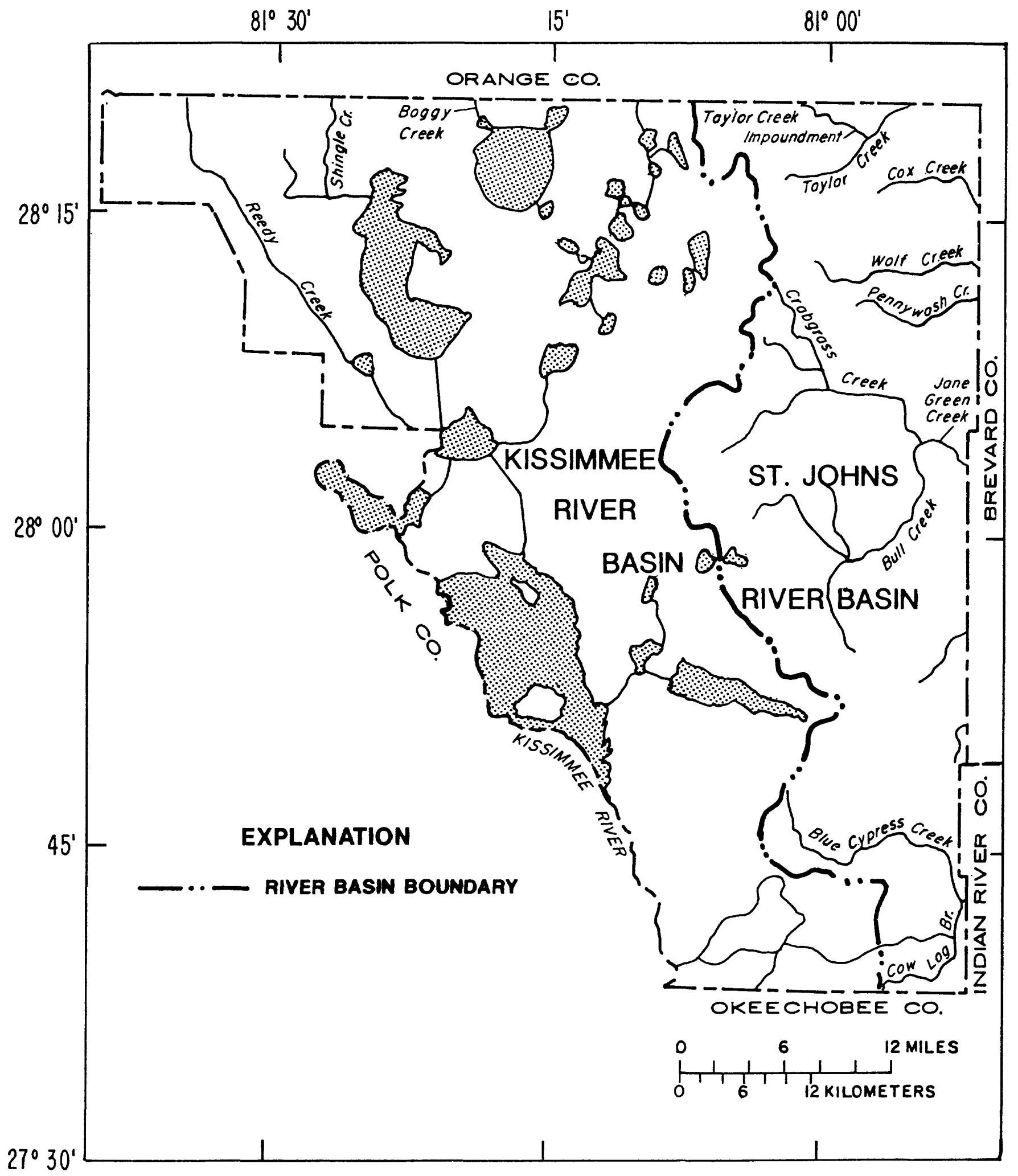

Figure 4. Drainage features of Osceola County. 

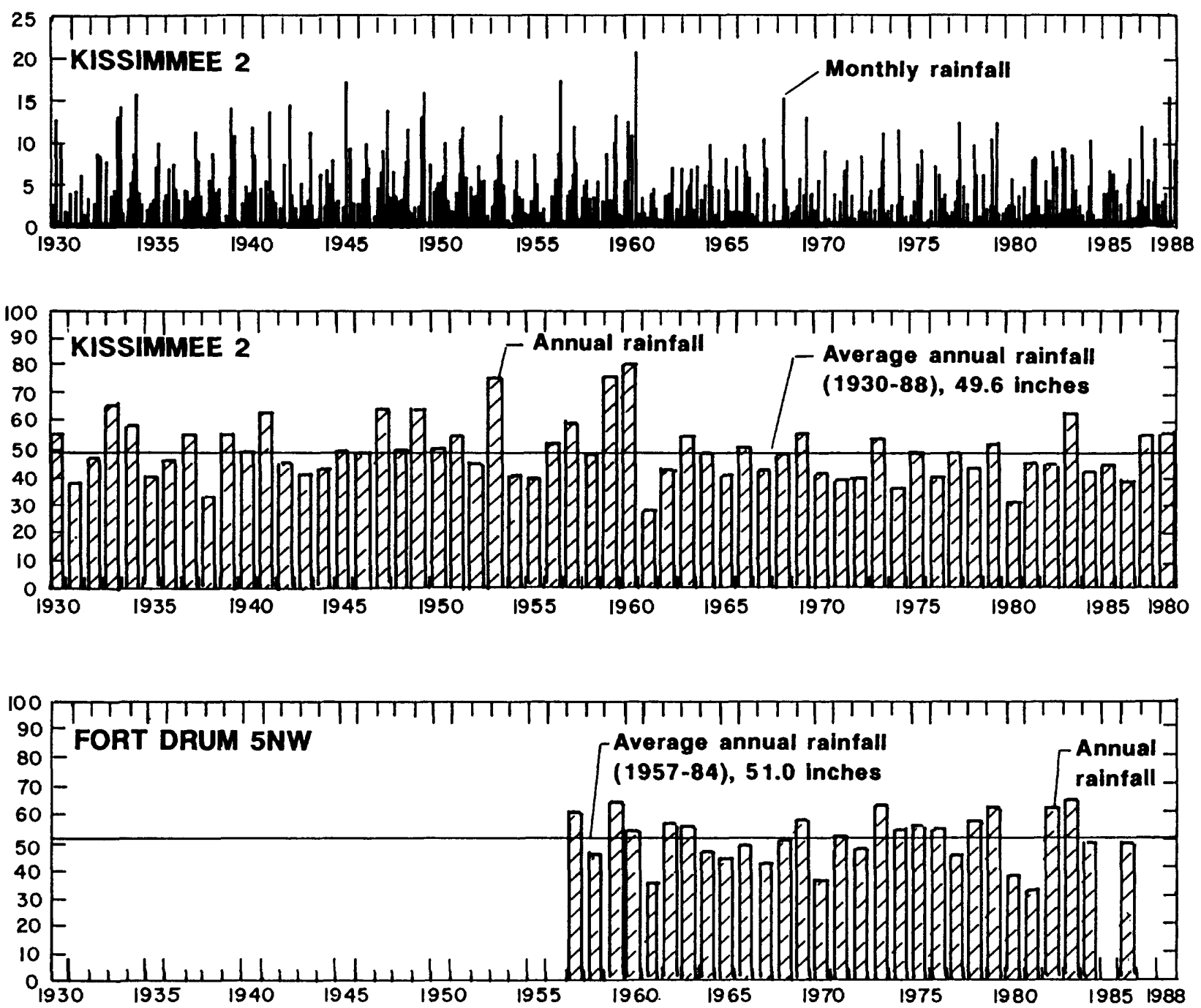

Figure 5. Annual and monthly rainfall at Kissimmee, 1930-88, and annual rainfall at Fort Drum, 1957-86.

\section{Geologic Framework}

The availability and quality of ground water and surface water in Osceola County is closely related to its geologic framework. Sedimentary rocks that range in thickness from about 6,800 to $8,700 \mathrm{ft}$ (Lloyd, 1985, p. 57) are on a basement complex of pre-Mesozoic metamorphic and volcanic rock. The top $1,200 \mathrm{ft}$ of sediments, significant to this study, is part of the Tertiary and Quaternary systems that range in age from Eocene (oldest) to Holocene (youngest). The lower $1,000 \mathrm{ft}$ of the sedimentary section consists of Eocene age carbonate rocks of the Avon Park Formation overlain by the Ocala Limestone. The maximum thickness of the Ocala Limestone is roughly $100 \mathrm{ft}$, but the formation is thin in places and is apparently absent owing to erosion in much of the northwestern and north-central part of the county (Miller, 1986, pl. 9). The upper $200 \mathrm{ft}$ of the section consists of the Hawthorn Formation of Miocene age that overlies the Ocala Limestone (Eocene), which is overlain by undifferentiated Pleistocene and Holocene age deposits. In the southern part of the county, a relatively thin, sandy limestone, correlative to the Tamiami Formation of Pliocene age, may lie between the Hawthorn Formation and the undifferentiated Pleistocene and Holocene strata. The Hawthorn Formation consists mostly of fine clastic rocks that contain variably thick, discontinuous beds of limestone at its base. The Hawthorn ranges in thickness from less than $1 \mathrm{ft}$ (northwestern part of the county) to greater than $300 \mathrm{ft}$ in places. Erosion of the Hawthorn Formation during Pleistocene time is largely responsible for the distribution of current karst (Bush and Johnston, 1988, p. C20). The undifferentiated rocks of Pleistocene and Holocene age consist mostly of post-Miocene age unconsolidated deposits of sand, sandy clay, and shell material that range in thickness from about $30 \mathrm{ft}$ to $270 \mathrm{ft}$. 
Table 1. Water-bearing characteristics and descriptions of the geologic units in Osceola County. [gal/min, gallons per minute]

\begin{tabular}{|c|c|c|c|c|c|c|c|}
\hline $\begin{array}{l}\text { Sys- } \\
\text { tem }\end{array}$ & Series & $\begin{array}{l}\text { Formation } \\
\text { name }\end{array}$ & $\begin{array}{l}\text { Thickness } \\
\text { (feet) }\end{array}$ & Description & Yield of wells & & $\begin{array}{l}\text { Hydrogeologic } \\
\text { unit }\end{array}$ \\
\hline 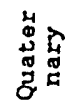 & $\begin{array}{l}\text { Holocene } \\
\text { and } \\
\text { Pleistocene }\end{array}$ & $\begin{array}{l}\text { Undifferentiated } \\
\text { deposits }\end{array}$ & $20-270$ & $\begin{array}{l}\text { Variable mixture of sand, } \\
\text { silt, clay, coquina, and } \\
\text { organic material }\end{array}$ & $\begin{array}{l}\text { Varies widely } \\
\text { but mostly less } \\
\text { than } 100 \mathrm{gal} / \mathrm{min}\end{array}$ & & $\begin{array}{l}\text { Surficial } \\
\text { aquifer } \\
\text { system }\end{array}$ \\
\hline \multirow{5}{*}{ 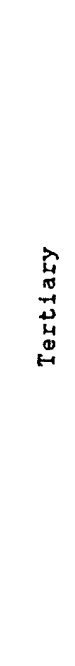 } & Miocene & $\begin{array}{l}\text { Kawthorn } \\
\text { Formation }\end{array}$ & $<1-370$ & $\begin{array}{l}\text { Silty to sandy clay, } \\
\text { thin sheli beds, and } \\
\text { basal limestone beds } \\
\text { of variable thickness, } \\
\text { phosphatic }\end{array}$ & $\begin{array}{l}\text { Generally less } \\
\text { than } 100 \mathrm{gal} / \mathrm{min}\end{array}$ & & $\begin{array}{l}\text { Intermediate } \\
\text { confining unit }\end{array}$ \\
\hline & \multirow{4}{*}{ Eocene } & Ocala Limestone & $0-200$ & $\begin{array}{l}\text { Limestone, dolomitic } \\
\text { near base in places }\end{array}$ & $\begin{array}{l}\text { Varies widely, } \\
\text { from about } 100 \\
\text { to more than } \\
700 \mathrm{gal} / \mathrm{min}\end{array}$ & \multirow{4}{*}{ 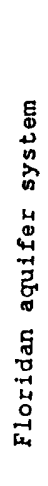 } & \multirow[t]{2}{*}{$\begin{array}{l}\text { Upper Floridan } \\
\text { aquifer }\end{array}$} \\
\hline & & \multirow{2}{*}{$\begin{array}{l}\text { Avon Park } \\
\text { Formation }\end{array}$} & $100-300$ & Limestone and dolomite & $\begin{array}{l}\text { Generally more } \\
\text { than } 700 \mathrm{gal} / \mathrm{min}\end{array}$ & & \\
\hline & & & $450-700$ & $\begin{array}{l}\text { Dolomite, dolomitic } \\
\text { limestone, limestone, } \\
\text { and some Bypsum }\end{array}$ & $\begin{array}{l}\text { Varies widely, } \\
\text { probably averages } \\
\text { much less than } \\
100 \mathrm{gal} / \mathrm{min}\end{array}$ & & $\begin{array}{l}\text { Middle semicon- } \\
\text { fining unit }\end{array}$ \\
\hline & & $\begin{array}{l}\text { Oldsmar } \\
\text { Formation }\end{array}$ & $600-700$ & Limestone and dolomite & $\begin{array}{l}\text { Probably less } \\
\text { than } 700 \mathrm{gal} / \mathrm{min}\end{array}$ & & $\begin{array}{l}\text { Lower Floridan } \\
\text { aquifer }\end{array}$ \\
\hline
\end{tabular}

Descriptions of the geologic formations tapped by wells in Osceola County are given in table 1. An interpretation of the gamma-ray $\log$ of well 113 , indicative of the general geology, is illustrated in fig. 6 (location of well 113 is shown in fig. 7). The hydrogeologic sections (see fig. 7 for location of lines of section) shown in figures 8,9 , and 10 indicate the thickness and extent of the geologic units in the study area.

\section{Hydrogeologic Framework}

The hydrogeologic framework through which ground water moves and is stored in the study area consists of two general rock types: consolidated carbonate rocks and the overlying unconsolidated rocks. Each rock unit contains aquifers with unique hydraulic characteristics that determine its potential to supply water for a particular use. The unconsolidated deposits comprise the surficial aquifer system (Southeastern Geological Society Ad Hoc Committee on Florida Hydrostratigraphic Unit Definition, 1986, p. 4), commonly known as the surficial aquifer. The carbonate rocks contain the Floridan aquifer system, formerly known as the Floridan aquifer (Miller, 1986, p. B2).

In this report, the terminology and definitions relating to the Floridan aquifer system are those used by Miller (1986). Miller (1986, p. B45) describes the Floridan aquifer system as a vertically continuous sequence of generally highpermeability carbonate rocks, mostly of middle and late Tertiary age, that are several orders of magnitude more permeable than the rocks that bound the system above and below.

The surficial aquifer system generally is underlain and separated from the Floridan aquifer system by the intermediate confining unit (Southeastern Geological Society Ad Hoc Committee on Florida Hydrostratigraphic Unit Definition, 1986, p. 5), a unit consisting of mostly fine-grained clastics with basal thin carbonate layers that retard the movement of water between the aquifer systems. The Floridan aquifer system has upper and lower water-bearing zones separated by a less permeable semiconfining unit (Tibbals, 1981, p. 7). Because the less permeable carbonate rocks are widespread as a unit within the Floridan aquifer system in peninsular Florida, Miller (1986, p. B45) divided the Floridan aquifer system in descending order into the Upper Floridan aquifer, a middle semiconfining unit, and the Lower Floridan aquifer.

A fault system that roughly extends northward from the southwest corner of the county along the entire length of the Kissimmee River lake basin to the northwest corner of the county was mapped by Miller (1986, p. B12). Displacement in the fault system is probably small, but might have some effect on the ground-water flow system. The fault system is not discernible from well records compiled for this report, however, and the fault system is not shown on the hydrogeologic sections in figures 8-10. 


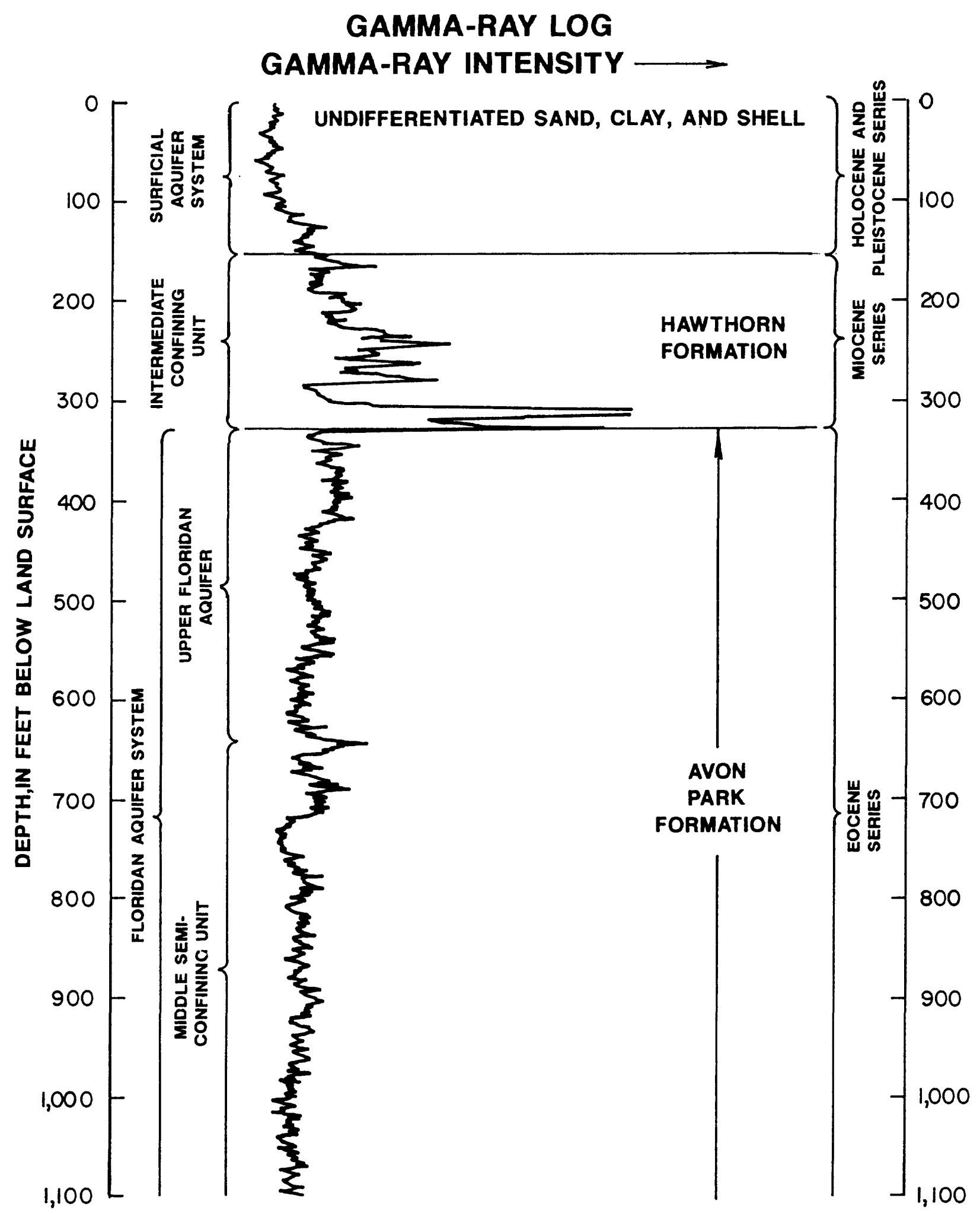

Figure 6. Gamma-ray log of well 113 showing geologic formations and hydrologic units. 


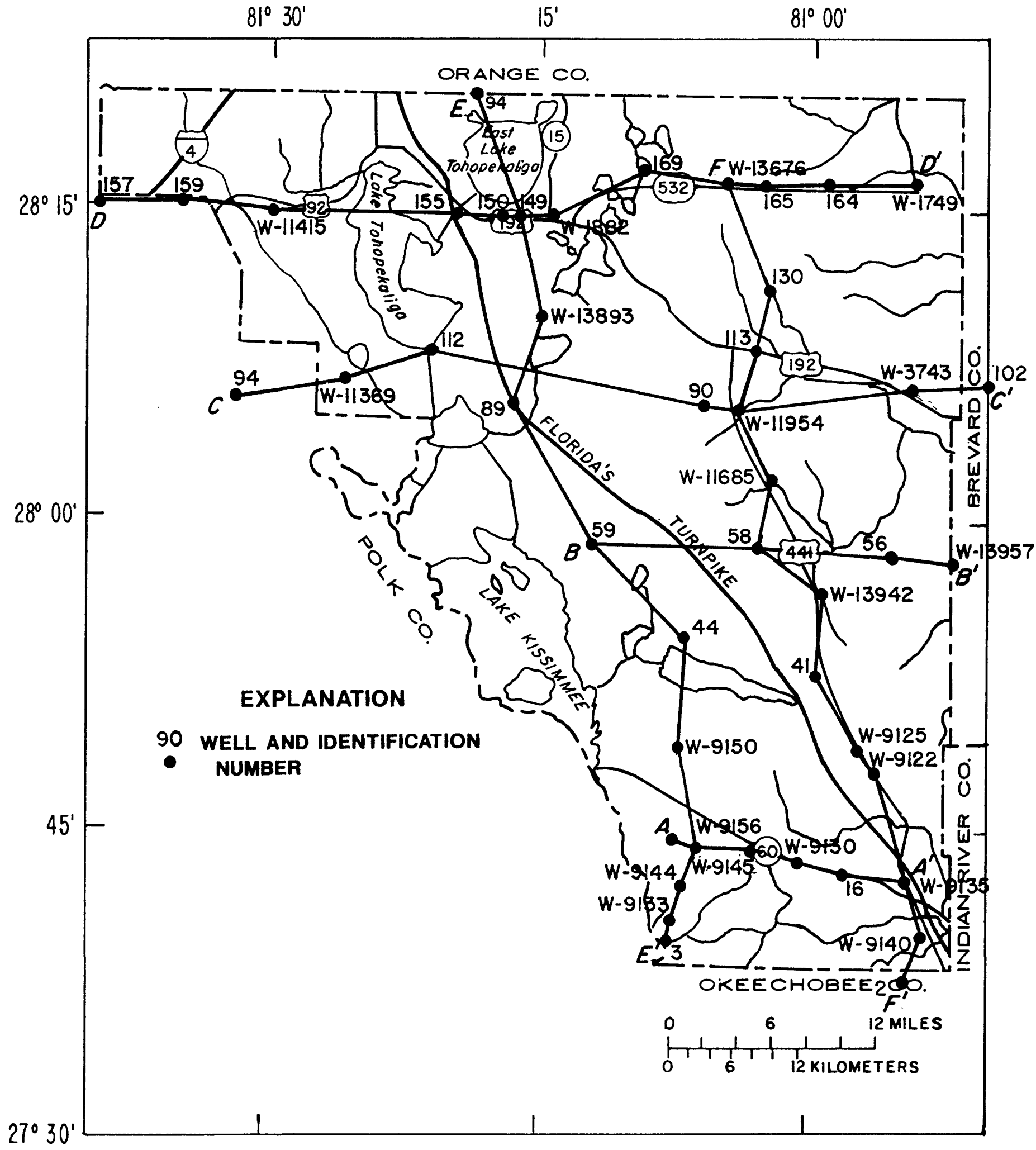

Figure 7. Location of lines of hydrogeologic sections. 


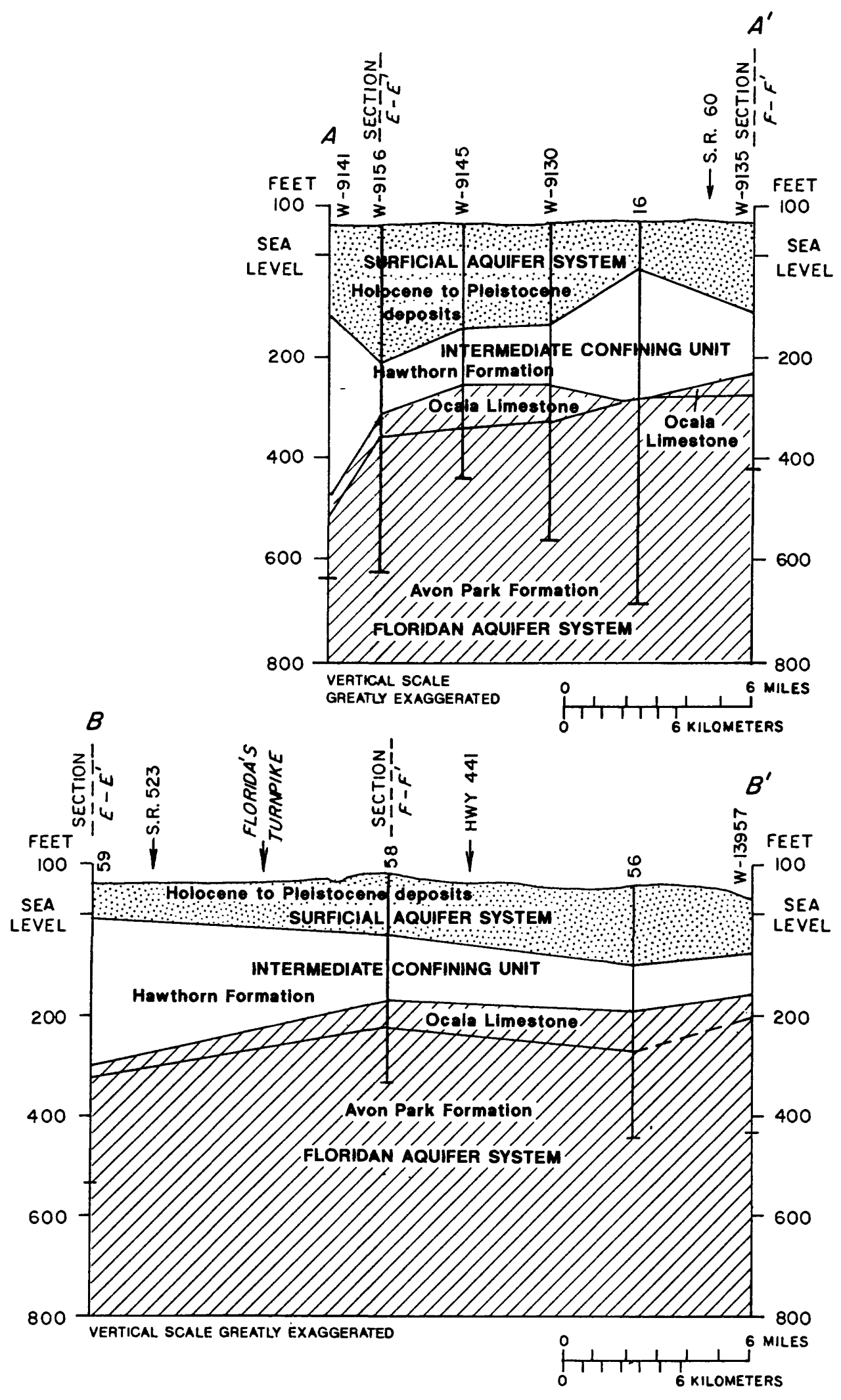

Figure 8. Hydrogeologic sections $A-A^{\prime}$ and $B-B^{\prime}$ showing geologic and hydrologic units (lines of sections shown in fig. 7). 

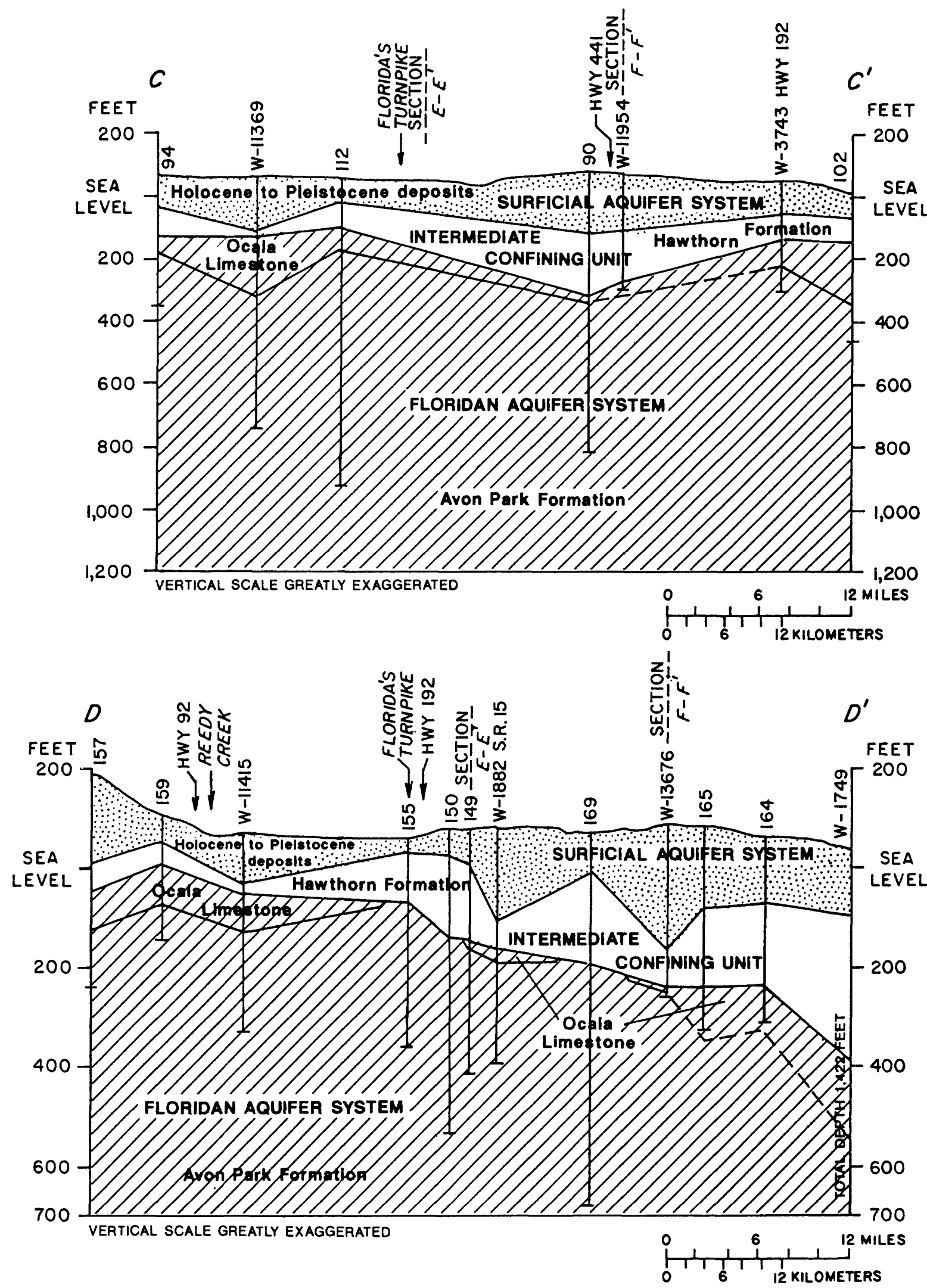

Figure 9. Hydrogeologic sections $C-C^{\prime}$ and $D-D^{\prime}$ showing geologic and hydrologic units (lines of sections shown in fig. 7). 


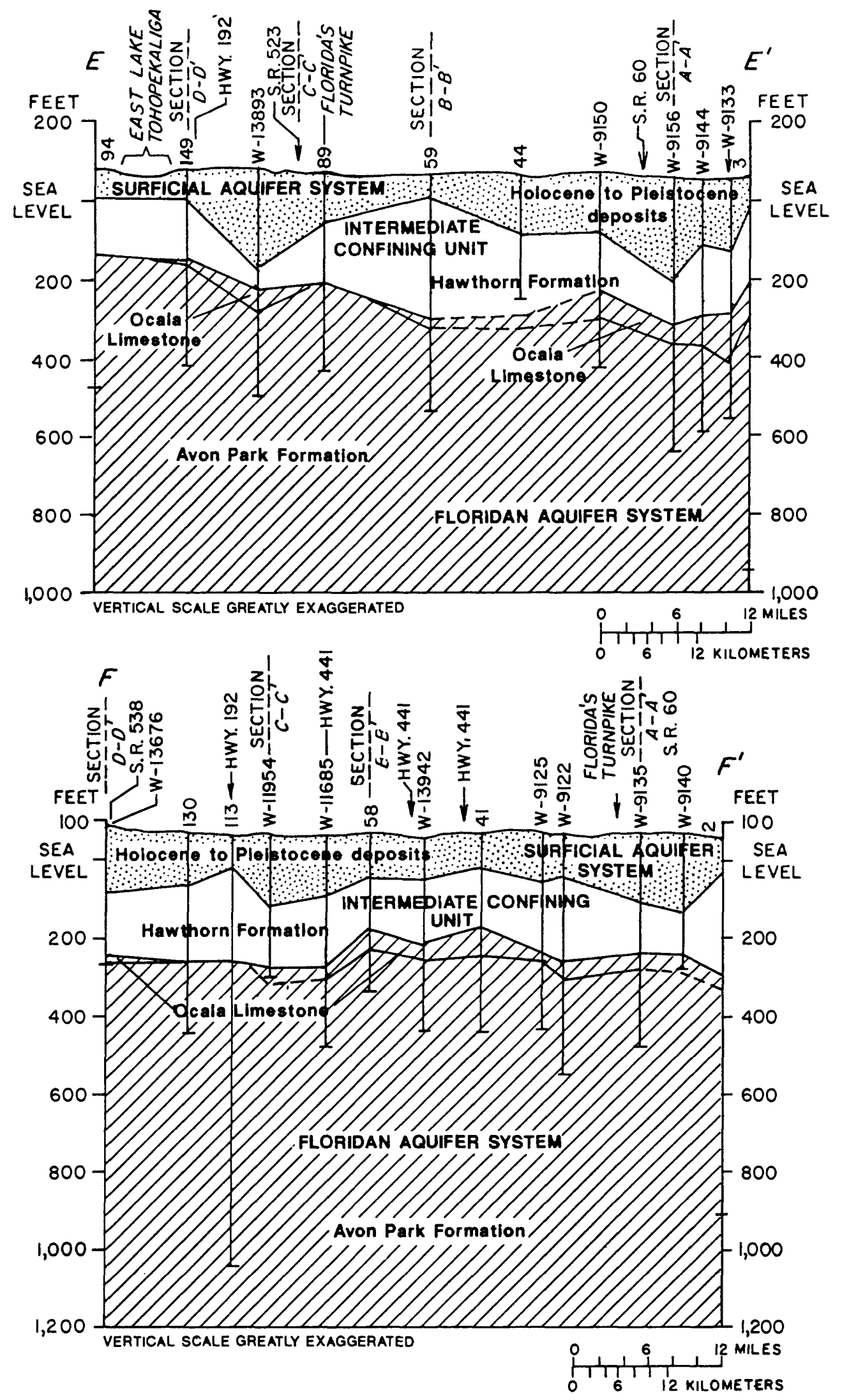

Figure 10. Hydrogeologic sections $E-E^{\prime}$ and $F-F^{\prime}$ showing geologic and hydrologic units (lines of sections shown in fig. 7). 


\section{Ground-Water Occurrence and Movement}

Ground water in the surficial aquifer system is generally unconfined, whereas in the Floridan aquifer system it is mostly confined. Bush and Johnston (1988, pl. 1) classified the Upper Floridan aquifer in the northwest quarter of Osceola County as a semiconfined area where the upper confining unit is less than $100 \mathrm{ft}$ thick, or breached. The Upper Floridan in the remainder of the county is classified as confined where the confining unit generally is greater than $100 \mathrm{ft}$ thick and is unbreached. The water table of the surficial aquifer system and the potentiometric surface of the Floridan aquifer system fluctuate continuously in response to changes in recharge and discharge. Directions of lateral ground-water flow in the two systems are indicated by the gradient of the water table and potentiometric surface.

In Osceola County, natural recharge to the surficial aquifer system is derived from local precipitation throughout most of the aquifer's extent. Additional recharge is by upward leakage from the Floridan aquifer system. Recharge to, or discharge from, the Floridan aquifer system is controlled by the relative positions of the water table and potentiometric surface. Recharge to the Floridan aquifer system occurs only where the head (water table) in the surficial aquifer system is higher than the head (potentiometric surface) in the Floridan aquifer system. Most recharge to the Floridan aquifer system occurs in the Lake Wales Ridge area of eastern Polk County (Frazee, 1980; and Phelps, 1984). Some recharge to the Floridan aquifer system takes place in the northwest comer of Osceola County where the overlying confining unit is absent, thin, or transmissive. Areas of natural recharge and discharge of the Floridan aquifer system are shown in figure 11. Natural discharge from the surficial aquifer system generally occurs by downward leakage to the Floridan aquifer system, evapotranspiration, and subsurface flow into the many lakes and streams. In the Floridan aquifer system, natural discharge is largely by way of upward leakage through the intermediate confining unit in the areas of discharge shown in figure 11.
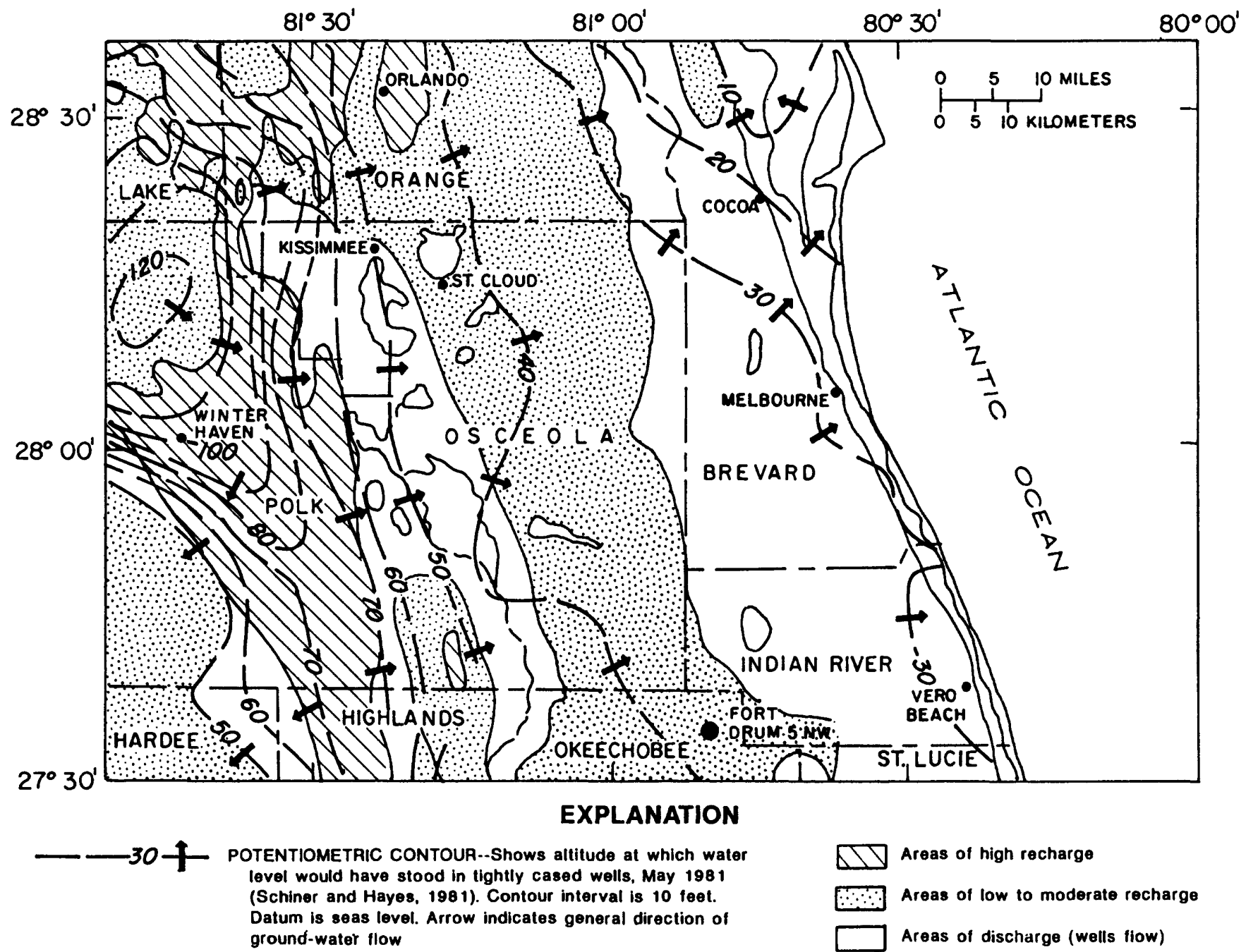

Figure 11. Potentiometric surface, May 1981, and areas of natural recharge and discharge of the Upper Floridan aquifer (modified from Phelps, 1984). 


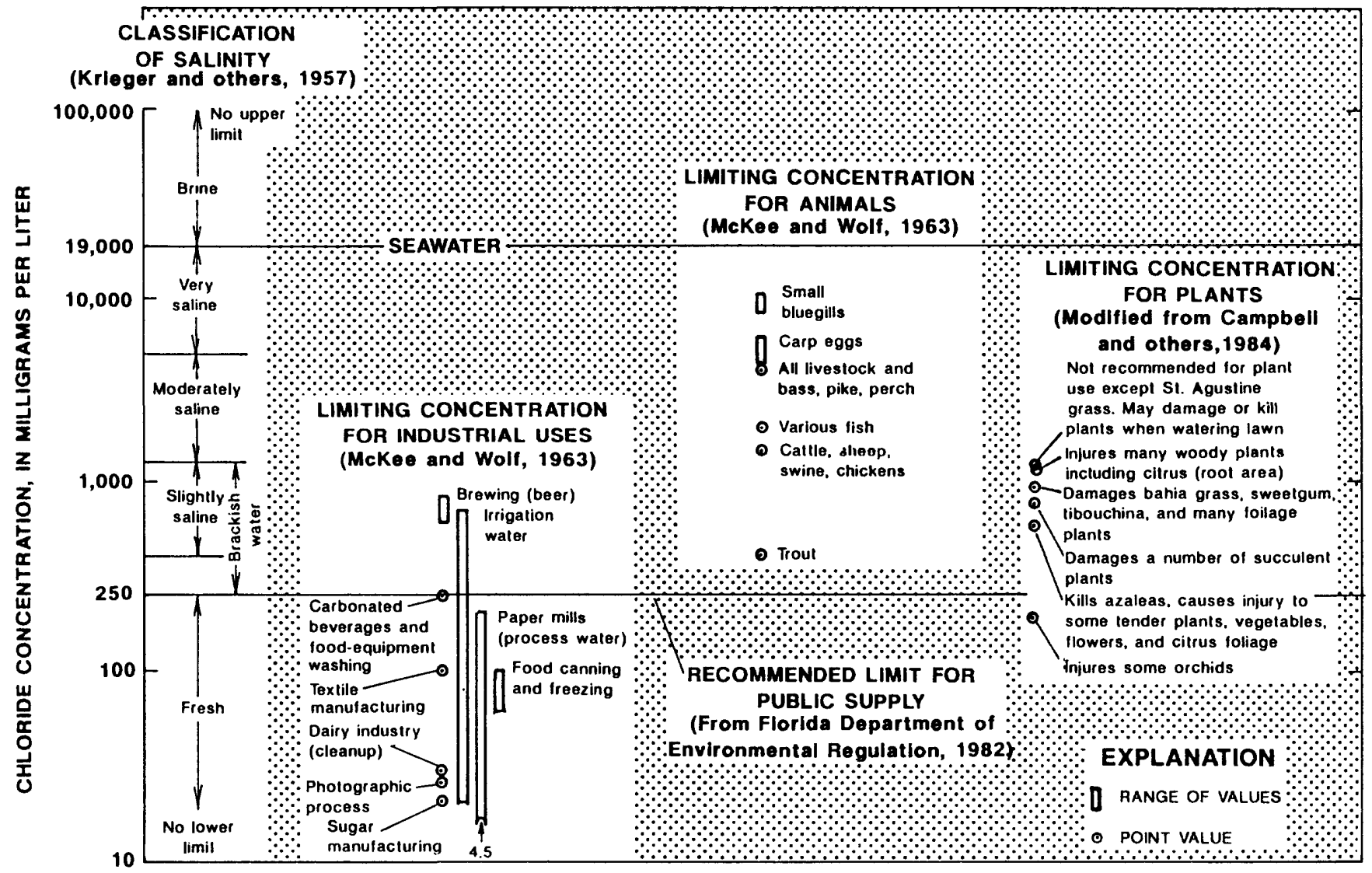

Figure 12. Classification of salinity and limiting concentrations of chloride recommended for plants, animals, public supply, and industrial use (from Schiner and others, 1988).

\section{Water Quality}

The amount, properties, and types of dissolved and suspended materials in water commonly control its use. Water suitable for one use may be unsatisfactory for other uses. For example, water that contains a moderate amount of dissolved solids can be used for irrigation but may not be suitable for canning or freezing some food. The chloride concentration and salinity of ground water in Osceola County are the most important criteria of water quality for public supply and agricultural use which together account for about 80 percent of the water used in the county. Hardness, due primarily to calcium and magnesium ions, may also be a significant water-quality criterion for public supply and domestic water use. High concentrations of iron (greater than $0.3 \mathrm{mg} / \mathrm{L}$ ) and sulfate (greater than $250 \mathrm{mg} / \mathrm{L}$ ) are occasional water-quality problems.

Chloride concentration is used in this report as an index to overall quality of water. Chloride concentrations of water in the surficial and Floridan aquifer systems can vary both areally and vertically because the geohydrologic conditions that control water quality differ from place to place. In places where the intermediate confining unit is thin or breached and is overlain by thin or permeable deposits of the surficial aquifer system, water quality in the surficial aquifer system and the upper part of the Floridan aquifer system is probably similar. In this report, water with a chloride concentration of $250 \mathrm{mg} / \mathrm{L}$ or less is considered fresh; above $250 \mathrm{mg} / \mathrm{L}$, the water is considered salty. The limiting concentrations of chloride recommended for plants, animals, and industrial uses are shown in figure 12.

The terminology used to describe the salinity of water in the county is from a classification system based on dissolved-solids concentration and uses the terminology of Krieger and others (1957).

Estimates of dissolved-solids and chloride concentrations can generally be obtained easily and inexpensively by measuring specific conductance, a measure of the capacity of water to conduct an electric current. Specific conductance varies with the concentration of dissolved mineral matter, the degree of ionization of the material, the temperature of the water, and is reported in microsiemens per centimeter at $25^{\circ} \mathrm{C}$. The relation between chloride concentration and specific conductance and between specific conductance and dissolved-solids concentration are shown in figures 13 and 14 , respectively. Most of the data used in plotting the graphs were from Osceola County, but some data from the border areas of adjacent counties were also used. Figure 13 shows 
specific conductance is approximately three to six times the chloride concentration in the area where the chloride ion is dominant, and in figure 14, that specific conductance is shown as slightly greater than one-and-a-half times the dissolved-solids concentration. In some less-mineralized waters, chloride may not be a major element and conductance may be more closely related to other constituents. On the left side of figure 13 , or low-range end, the data are from waters not dominated by chloride concentration.

Hardness is expressed in terms of milligrams per liter of calcium carbonate $\left(\mathrm{CaCO}_{3}\right)$. A much referenced classification of hardness by Durfor and Becker $(1964$, p. 27) considers water soft if its hardness value lies between 0 and $60 \mathrm{mg} / \mathrm{L}$, moderately hard between 61 and $120 \mathrm{mg} / \mathrm{L}$, hard between 121 and $180 \mathrm{mg} / \mathrm{L}$, and very hard for values greater than $180 \mathrm{mg} / \mathrm{L}$ of $\mathrm{CaCO}_{3}$.

\section{GEOHYDROLOGY OF THE SURFICIAL AQUIFER SYSTEM}

The surficial aquifer system underlies the entire study area and consists of relatively thick sediments of Pleistocene age and thin Holocene deposits that overlie the intermediate confining unit (Hawthorn Formation). The aquifer consists of unconsolidated clastic deposits composed of sand, silt, and clay that differ both in thickness from place to place and in the proportion of the various components. Clay content commonly increases with depth, consequently the contact between the aquifer and the clayey upper unit of the underlying confining unit (Hawthorn Formation) is indistinct in many places. The surficial aquifer system ranges in thickness from about $30 \mathrm{ft}$ in the northwestern part of the county to about $270 \mathrm{ft}$ in the southern part of the county. It generally thickens eastward in the county (figs. 8, 9, and 10) and is thickest where it locally fills the depressions in the underlying paleokarstic surface (fig. 15). The surficial aquifer system generally is unconfined, but in places permeable sections of the aquifer may be semiconfined or confined between beds of low permeability. The most permeable part of the surficial aquifer system generally is the top $100 \mathrm{ft}$.

\section{Hydraulic Properties}

The hydraulic properties of the surficial aquifer system in Osceola County vary considerably from place to place depending on characteristics such as grain size, sorting, packing, cementation, and the thickness of the unit. These properties are reflected in values of transmissivity, storage,

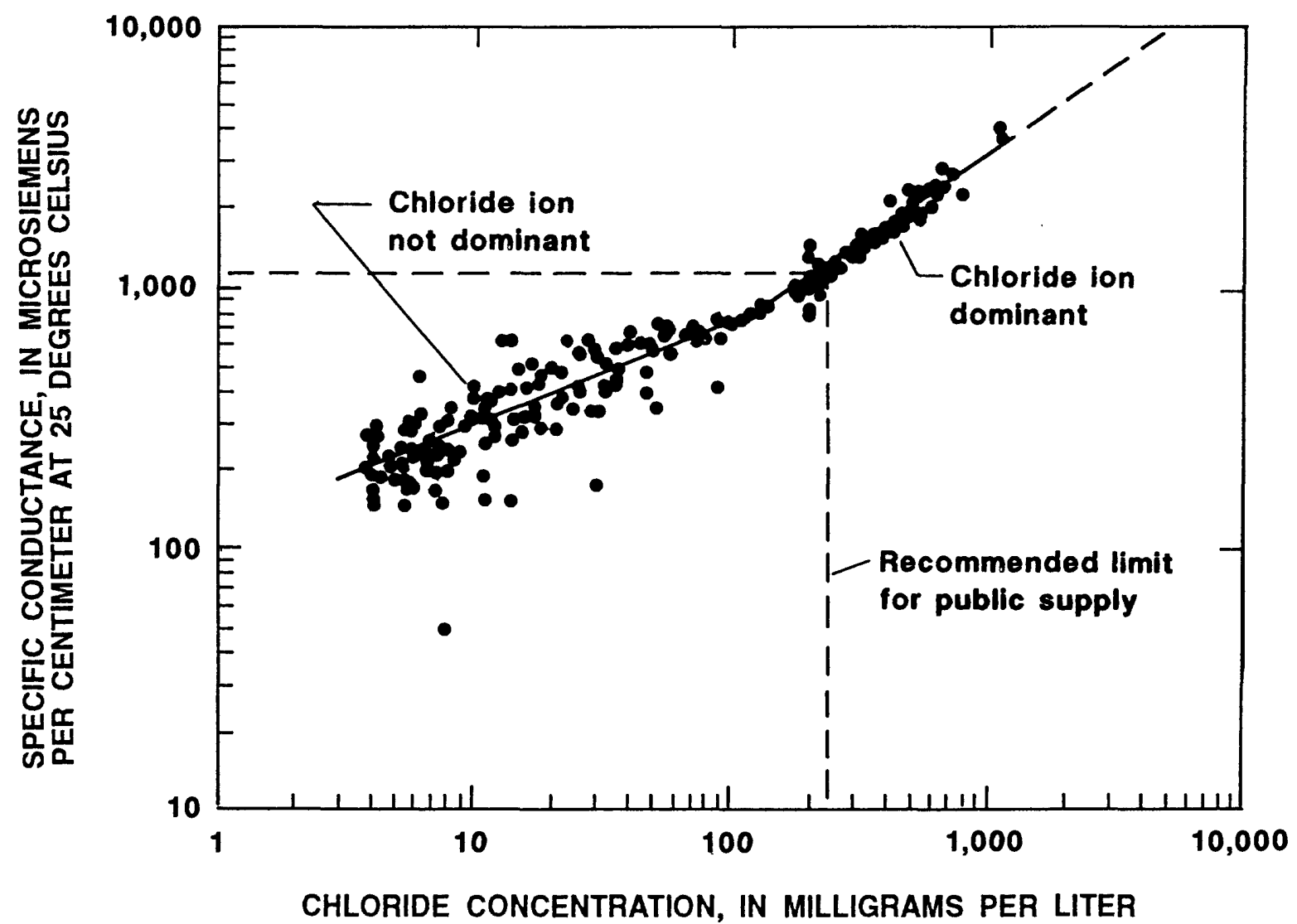

Figure 13. Relation between chloride concentration and specific conductance. 


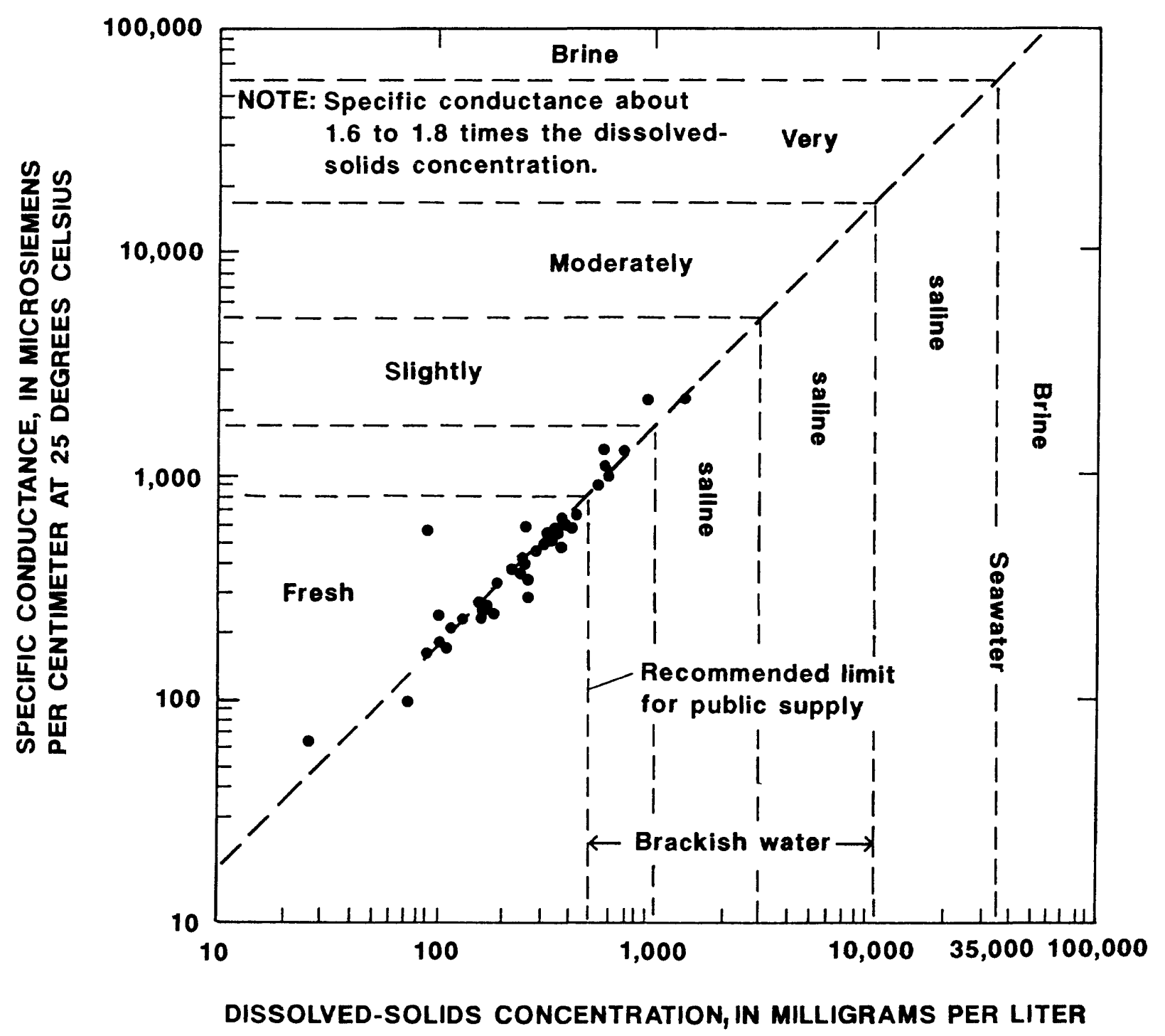

Figure 14. Relation between specific conductance and dissolved-solids concentration, and the classification of salinity of water.

hydraulic conductivity, and specific capacity that indicate the ability of an aquifer to yield water. Transmissivity is a measure of the rate at which water moves through a unit width of an aquifer under a unit hydraulic gradient. Similar to transmissivity is hydraulic conductivity, defined as the rate of water flow through a unit cross section of an aquifer under a unit hydraulic gradient. The storage coefficient is associated with the storage of water within the aquifer. It is the volume of water an aquifer releases from or takes into storage per unit surface area of the aquifer per unit change in head. Specific capacity relates the discharge of a well to the drawdown of the water level in the well. It is defined as the well discharge per unit of drawdown (gallon per minute per foot). Leakance is a characteristic of the confining units adjacent to the aquifer, and is a measure of the ability of confining units to transmit water to adjacent aquifers. It is the ratio of the vertical hydraulic conductivity and the thickness of the confining unit. Generally, the larger the value for transmissivity, hydraulic conductivity, and specific capacity, the more productive the aquifer.

Few data other than reported well yields are available on the hydraulic characteristics of the surficial aquifer system in Osceola County. A study by Planert and Aucott (1985) reported on two aquifer tests made on the surficial aquifer system. A test in the central part of Osceola County in the Three Lakes Management area (fig. 16) made with a $90-\mathrm{ft}$ deep, 6-in. diameter well, completed in a semiconfined shell and fine sand interval, indicated a transmissivity of 400 $\left[\left(\mathrm{ft}^{3} / \mathrm{d}\right) / \mathrm{ft}^{2}\right] \mathrm{ft}$ for the aquifer and a specific capacity of 1.7 ( $\mathrm{gal} / \mathrm{min}) / \mathrm{ft}$ for the pumped well. A vertical hydraulic conductivity of $0.005 \mathrm{ft} / \mathrm{d}$ was reported for the overlying confining bed and $0.09 \mathrm{ft} / \mathrm{d}$ for the underlying confining bed 


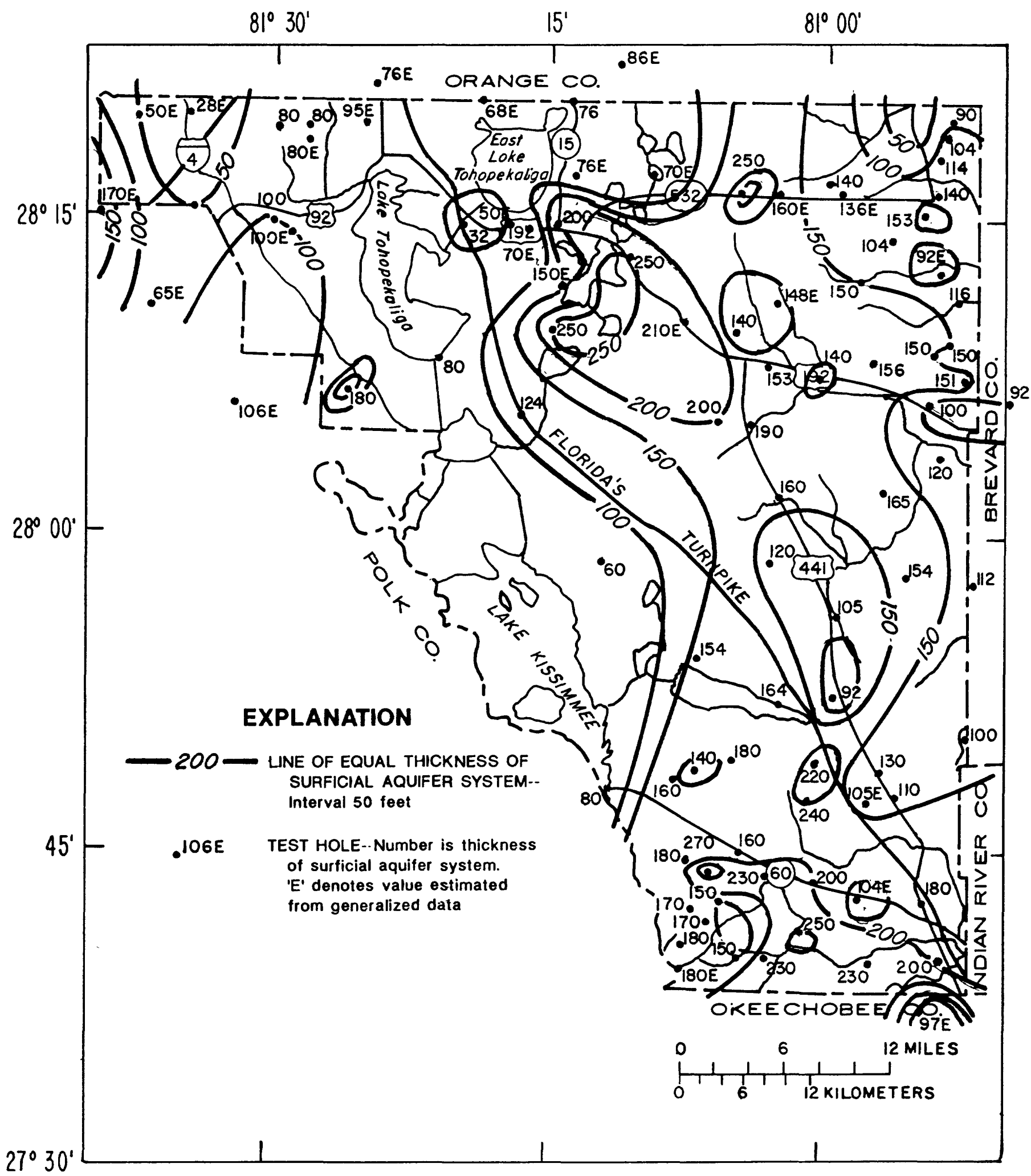

Figure 15. Thickness of the surficial aquifer system. 


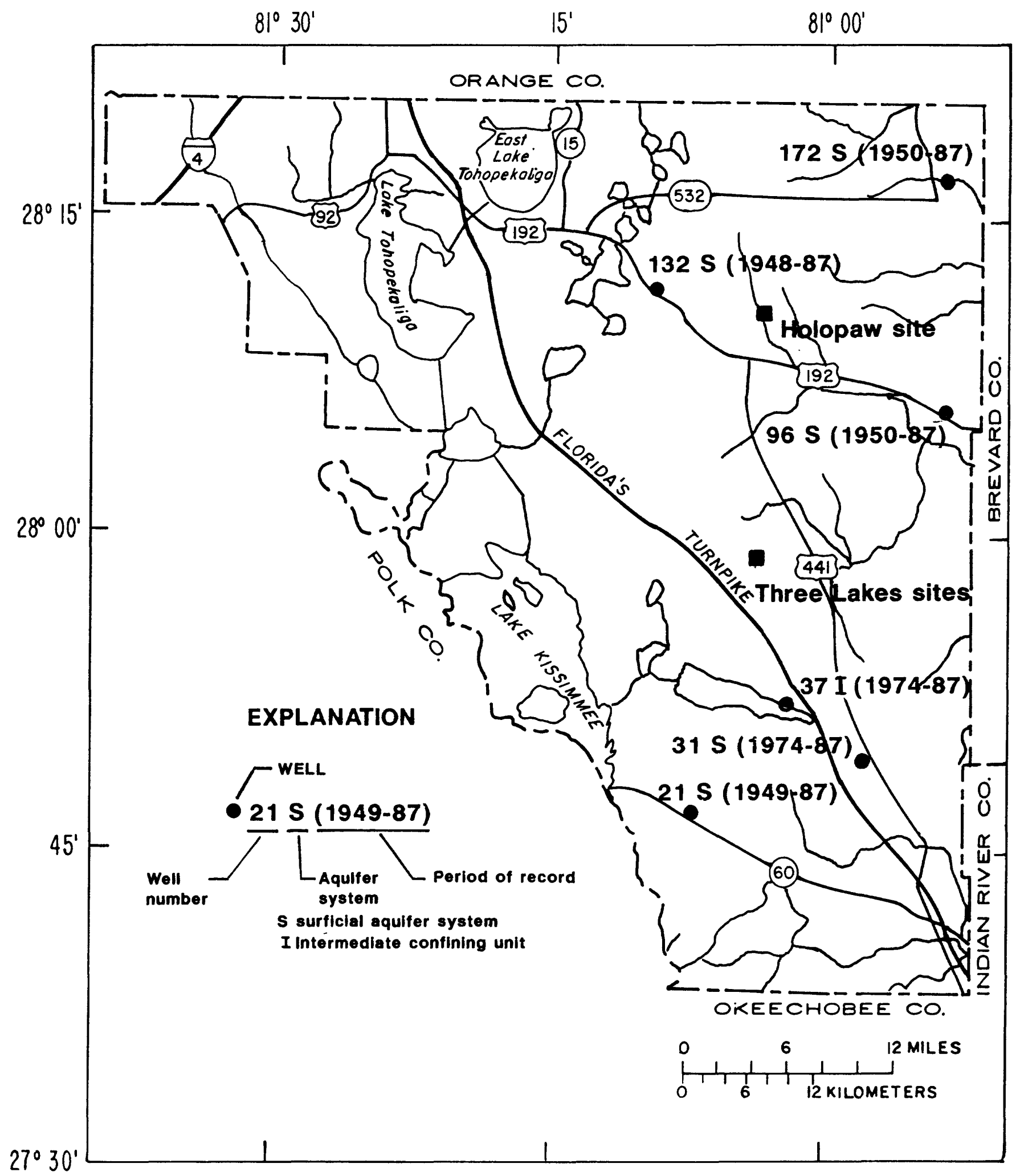

Figure 16. Location of test sites and wells in the surficial aquifer system and intermediate confining unit for which hydrographs are shown. 
(Planert and Aucott, 1985, p. 20). The second test, in northcentral Osceola County northeast of Holopaw, (Holopaw site in fig. 16), was made with a 75-ft deep, 6-in. diameter well, completed in clean shells grading to limestone fragments. A transmissivity of $2,000\left[\left(\mathrm{ft}^{3} / \mathrm{d}\right) / \mathrm{ft}^{2}\right] \mathrm{ft}$ and a storage coefficient of 0.0004 was reported for the shell and fragmented limestone interval (Planert and Aucott, 1985, p. 23). Reported vertical hydraulic conductivity for the upper confining layer was $0.05 \mathrm{ft} / \mathrm{d}$ and for the lower confining layer $1.2 \mathrm{ft} / \mathrm{d}$. Analyses of results of the two tests indicated a range of hydraulic conductivity of $20 \mathrm{ft} / \mathrm{d}$ to $100 \mathrm{ft} / \mathrm{d}$ for the aquifer zones tested and $0.005 \mathrm{ft} / \mathrm{d}$ to $1.2 \mathrm{ft} / \mathrm{d}$ for the confining materials (Planert and Aucott, 1985, p. 23). Tibbals (1981, p. 13) selected an arbitrary value of $1,000\left[\left(\mathrm{ft}^{3} / \mathrm{d}\right) / \mathrm{ft}^{2}\right] \mathrm{ft}$ for the transmissivity of the surficial aquifer system in a digital computer model that included Osceola County. Storage coefficients are probably within the range common for unconfined sand aquifers, about 0.05 to 0.2 .

\section{Water Levels}

Most heads in the surficial aquifer system are represented by the position of the water table. The water table usually ranges from about 2 to $20 \mathrm{ft}$ below land surface and typically is shaped as a subdued reflection of the topography. In low, flat, poorly drained areas, the water table commonly stands at or within a few feet of the land surface. In these areas, heavy rainfall can cause the water table to rise above the land surface. (See hydrograph of observation well 172 in fig. 21.) In areas of relatively high land-surface altitudes, such as in the northwestern corner of the county (altitudes exceed $200 \mathrm{ft}$ ), the depth to the water table may exceed $20 \mathrm{ft}$.

Water levels in wells tapping the surficial aquifer system in the county fluctuate in response to seasonal changes in precipitation and evapotranspiration. Water levels also may fluctuate in response to pumping and manipulation of flows in the drainage network in the county. Peak levels are reached during rainy seasons, commonly in late spring and summer. Minimum levels occur in the winter and early spring. For the same amount of rainfall, the magnitude of water-level fluctuations may differ from place to place because of differences in aquifer permeability and porosity.

Hydrographs showing three long-term $(38,38$, and 37 years) and two short-term (13 and 14 years) fluctuations of water levels in wells completed in the surficial aquifer system (see fig. 16 for locations) are shown in figures 17 through 21 . The hydrographs indicate that seasonal fluctuations of water levels in the surficial aquifer system average about $5 \mathrm{ft}$. The magnitude of seasonal high levels in the summer and low levels in the winter are apparently locally controlled by variations in the pattern of rainfall. For example, though the 1980-81 precipitation at Kissimmee was one of two of the lowest rainfalls for the period of record, water levels in well 21 (fig. 17) fell below the lowest level reached in 1981 in at least 7 other years of the 39-year observation well record though total yearly rainfall amounts were considerably higher. Well 172 , however, more closely tracks the total yearly precipitation record for Kissimmee (fig. 21). A comparison of water levels in surficial aquifer system observation well 132 and Upper Floridan aquifer observation well 169 (figs. 22 and 32) indicates that fluctuations of the water table and potentiometric surface in a recharge area of the Upper Floridan are similar, but the magnitude of water-level fluctuations generally is smaller in the surficial than in the Upper Floridan aquifer because the coefficient of storage of the surficial aquifer is much higher than that of the Floridan.

\section{Recharge and Discharge}

The surficial aquifer system in Osceola County is recharged primarily by infiltration of rainfall. Other sources of recharge are seepage from streams, lakes, and irrigated lands. Where heads in the underlying Floridan aquifer system are higher than those in the surficial aquifer system, there is upward leakage from the Floridan. However, little upward leakage to the surficial system occurs within Osceola County because a thick confining unit of low permeability (the Hawthorn Formation) effectively separates the surficial and Floridan aquifer systems. Discharge from the surficial aquifer system is principally by evapotranspiration. Some discharge occurs as seepage into lakes, streams, canals, ditches, and withdrawal from wells.

Heads in the surficial aquifer system rise and decline during wet and dry periods in response to recharge and discharge. The hydrograph of well 31 (fig. 18) illustrates the relation between monthly rainfall at Kissimmee and water levels in the well. In September 1981, the water level in well 31 rose $5.4 \mathrm{ft}$ from the August level in response to a total of 14.9 in. of rainfall in August and September. Though water levels have fluctuated seasonally and have shown downward and upward trends for considerable periods, the hydrographs indicate no significant long-term trend toward higher or lower levels. Therefore, recharge from summer rains generally has been able to replenish discharge from the surficial aquifer system and long-term changes in storage are negligible.

\section{Water Quality}

Major factors that control the quality of water in the surficial aquifer system are the quality and quantity of rainfall that infiltrates the aquifer system, and aquifer-system properties such as permeability and sediment type. In eastern Osceola County, where the potentiometric surface of the 

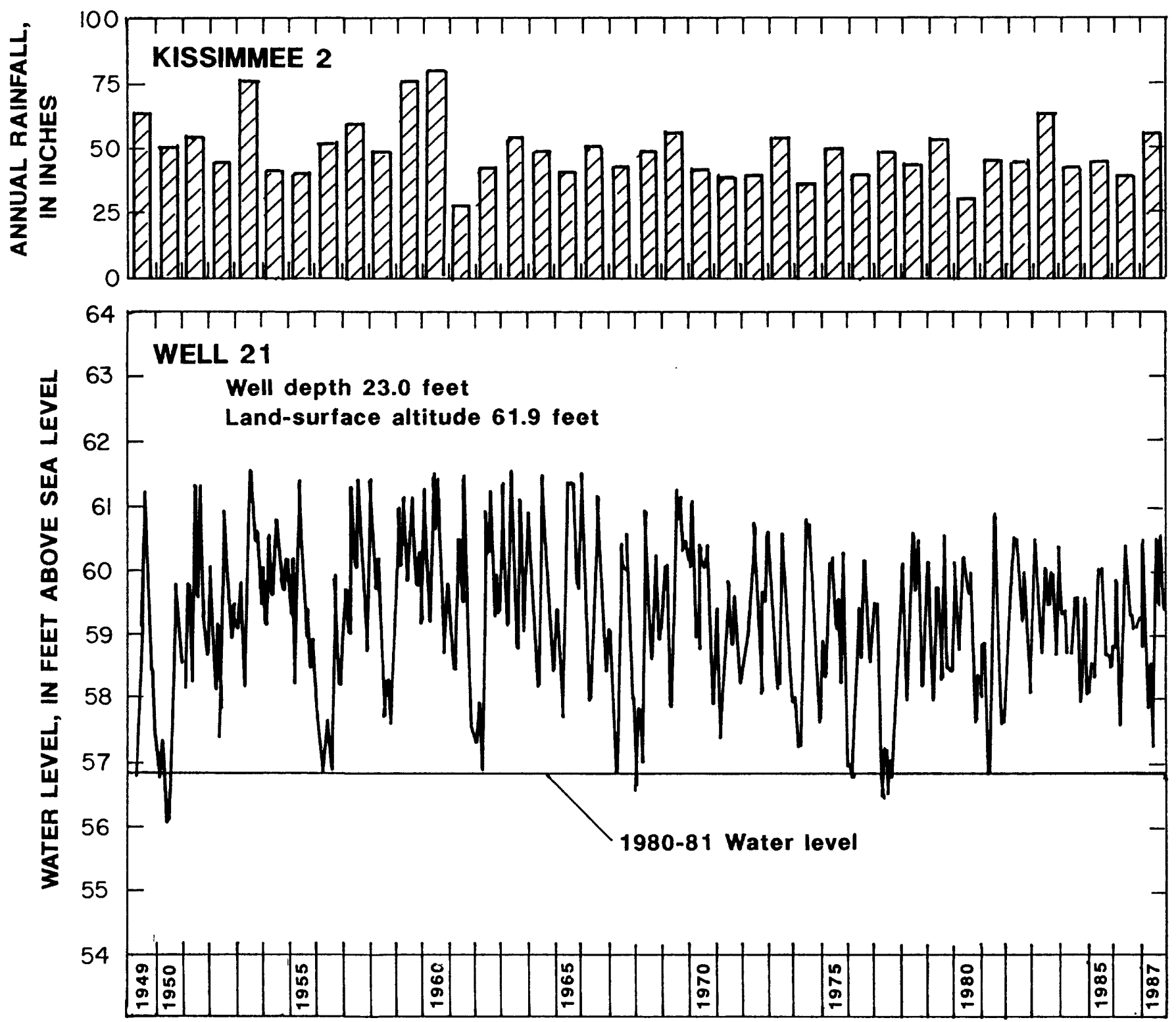

Figure 17. Water level in well 21, and annual rainfall at Kissimmee, 1949-87.

underlying Floridan aquifer system is higher than the water table of the surficial aquifer system, the salinity of surficial ground water may be high because of the infiltration of saline Upper Floridan aquifer water used for irrigation, or contamination of the shallow ground water with more saline water from the Floridan aquifer system through leaking well casings. Contamination due to upward leakage through the intermediate confining unit is minimal because of the thickness of the unit.

Quality of water from the surficial aquifer system has been determined at relatively few locations. Water type is variable from location to location (fig. 23), but is generally a calcium bicarbonate type of low ionic strength (specific conductances less than $600 \mu \mathrm{S} / \mathrm{cm}$ ).
The quality of water in the surficial aquifer system generally meets State of Florida secondary drinking water standards, except for iron (table 2). Chloride and sulfate concentrations probably are significantly less than the $250 \mathrm{mg} / \mathrm{L}$ limit (Florida Department of Environmental Regulation, 1990) at most locations. As noted previously, saline water from the Floridan aquifer system introduced into the surficial aquifer system by irrigation or through leaking well casings could locally result in chloride concentrations greater than the $250 \mathrm{mg} / \mathrm{L}$ standard. Iron concentrations may greatly exceed the $300 \mu \mathrm{g} / \mathrm{L}$ limit at many locations. Water from well 21 (table 2) contained more than $25,000 \mu \mathrm{g} / \mathrm{L}$ of iron. Corrosion of iron well casings may contribute to excessive iron concentrations in water from many wells. 


\section{Availability of Water}

About 10 percent of the ground water used in Osceola County is derived from wells that tap the surficial aquifer system. Yields of wells range widely from about 15 to 300 $\mathrm{gal} / \mathrm{min}$, depending primarily upon the permeability and thickness of the water-bearing zone. Other factors that may affect well yield are well diameter, the absence or use of well screens, extent of well development, and type of pump. In the eastern part of the county, saline water commonly occurs at relatively shallow depths in the Upper Floridan aquifer. There, the surficial aquifer system is commonly tapped to obtain small to moderate water supplies.

Frazee (1980) reported that wells in the surficial aquifer system yield appreciable quantities of water in at least five areas of the county. In northwestern Osceola, as much as 20 $\mathrm{gal} / \mathrm{min}$ are obtained from small-diameter wells (1-2 in.) that range in depth from 10 to $100 \mathrm{ft}$. About $3 \mathrm{mi}$ west of Lake Tohopekaliga, appreciable well yields are obtained from wells that tap a water-bearing unit that extends from 45 to $94 \mathrm{ft}$ below land surface. Eastward from this area, yields of as much as $15 \mathrm{gal} / \mathrm{min}$ are reported. In the area of East Lake Tohopekaliga, yields of 15 to $20 \mathrm{gal} / \mathrm{min}$ are obtained from wells generally $50 \mathrm{ft}$ or less in depth. In the vicinity of Yeehaw Junction, reported yields of as much as $300 \mathrm{gal} / \mathrm{min}$ are obtained from 4-in. diameter wells screened at depths of about $100 \mathrm{ft}$ below land surface.

According to Frazee (1980), in a relatively large area of south-central and southeastern Osceola County, the surficial aquifer system contains a semiconfined water-bearing sand and shell unit, the top of which ranges from 30 to $40 \mathrm{ft}$ below land surface in south central Osceola to about $110 \mathrm{ft}$ below land surface in the southwestern corner of the county. The unit thickens from about $25 \mathrm{ft}$ in the northern and western areas of the county to about a 60 - to 70 -ft thickness in southeastern areas of the county. Though yields up to 300 $\mathrm{gal} / \mathrm{min}$ probably can be obtained from the aquifer system in the central part of the county, the unit is little used because the underlying Upper Floridan aquifer can supply relatively large yields of acceptable quality water.
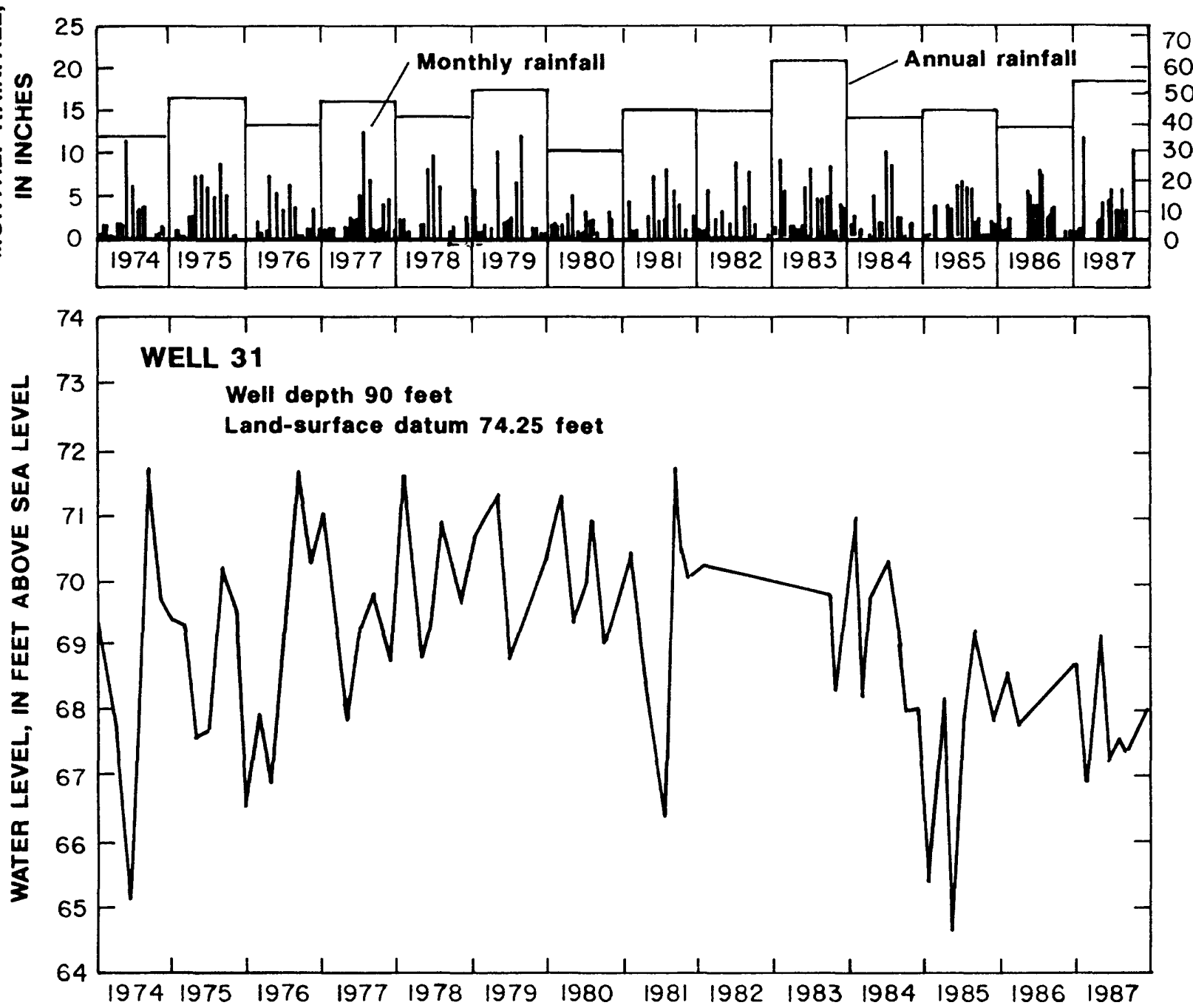

Figure 18. Water level in well 31 , and annual rainfall at Kissimmee, 1974-87. 


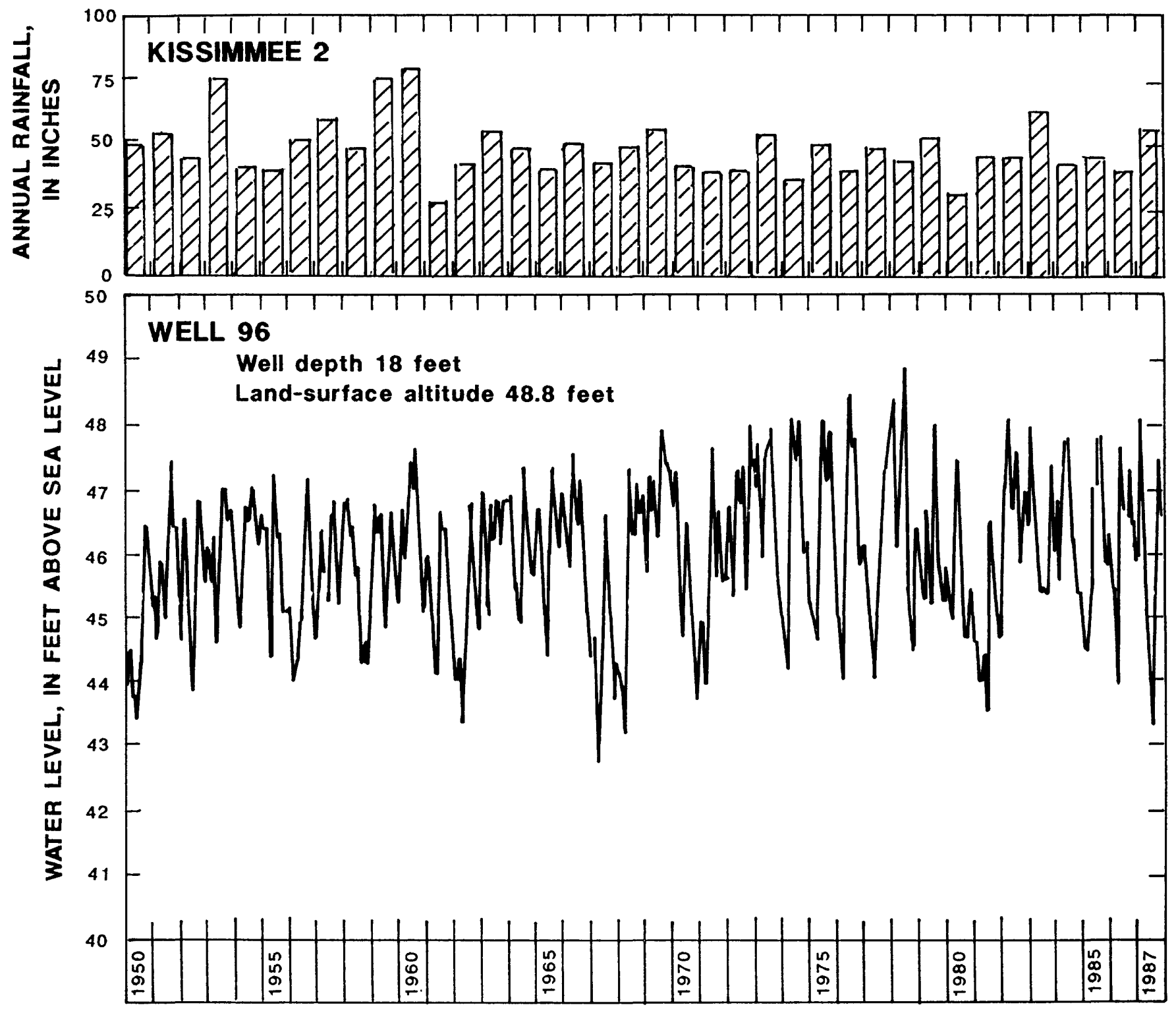

Figure 19. Water level in well 96, and annual rainfall at Kissimmee, 1950-87.

In general, wells completed in the surficial aquifer system commonly yield about $15 \mathrm{gal} / \mathrm{min}$ throughout the county. Higher yields are probable in southeastern Osceola County.

\section{GEOHYDROLOGY OF THE INTERMEDIATE CONFINING UNIT}

The Hawthorn Formation of Miocene age forms the intermediate confining unit (table 1), a low-permeability sequence of rocks that separates the overlying surficial aquifer system from the underlying Floridan aquifer system. The upper part of the intermediate confining unit is mostly unconsolidated, clayey, and silty, and the lower part generally consists of complexly interbedded, variably thick beds of impure limestone, sandstone, and clays that contain phosphate. The intermediate confining unit ranges considerably in thickness but generally thickens to the south and east in Osceola County from about $40 \mathrm{ft}$ in the northwestern part of the county to about $150 \mathrm{ft}$ in the southern part (fig. 24). The thickness exceeds $300 \mathrm{ft}$, in a small area northeast of Lake Kissimmee. Where the intermediate confining unit is less than about $100 \mathrm{ft}$ thick, water in the underlying Floridan aquifer system is considered to be under semiconfined conditions. There, the intermediate confining unit may be breached by sinkholes and other openings that formed in the underlying limestone of the Floridan aquifer system (Miller, 1986, p. B43).

The lowest part of the intermediate confining unit often contains permeable zones of limestones and sandy limestones. Their permeability is considerably less than the 

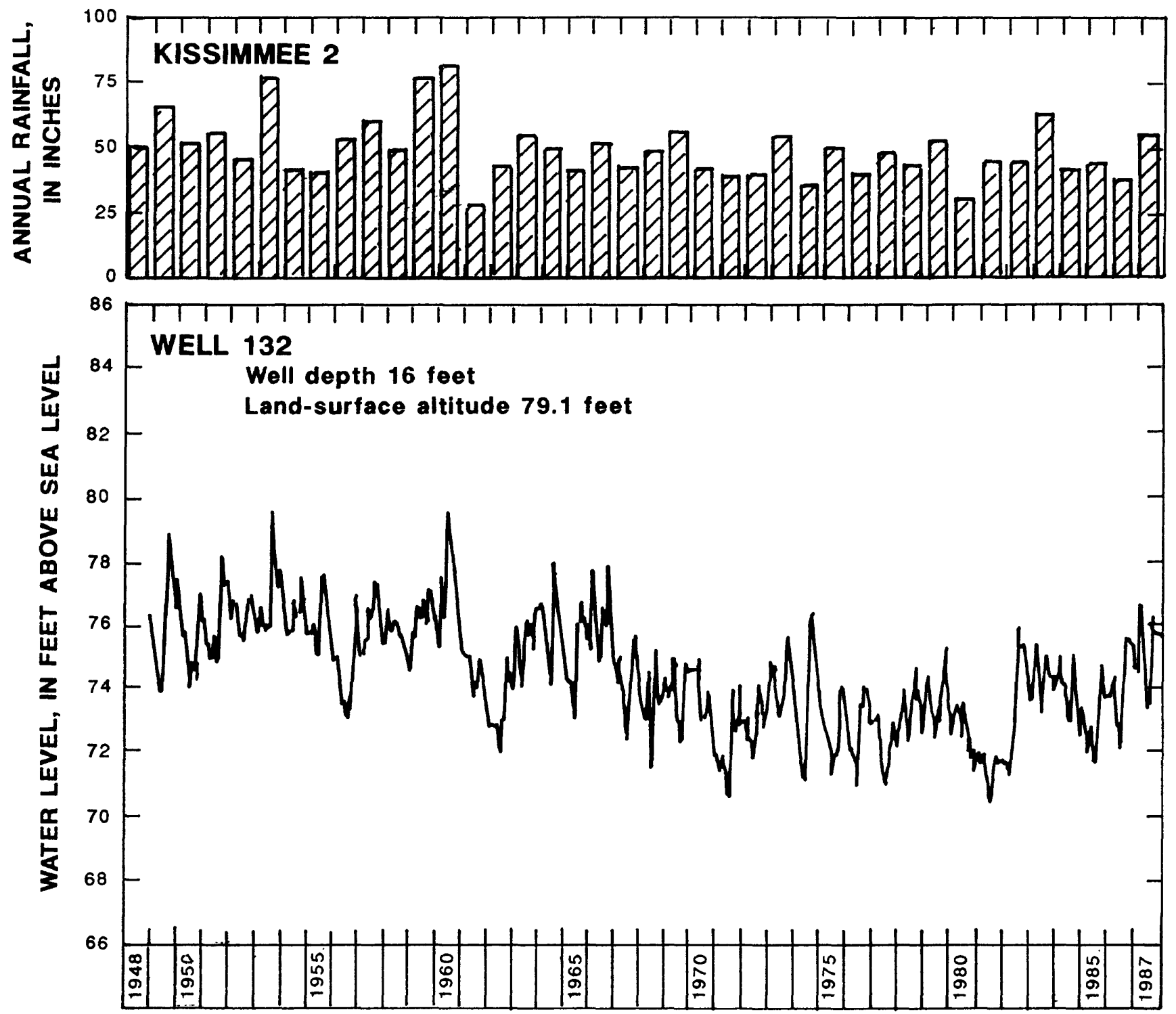

Figure 20. Water level in well 132, and annual rainfall at Kissimmee, 1948-87.

permeability of the underlying Floridan aquifer system, and accordingly, they are not considered part of the Floridan. Little is known about the hydraulic characteristics of the intermediate confining unit. Miller (1986, p. B43) reported vertical hydraulic conductivity values for clays of the Hawthorn Formation ranging from $1.5 \times 10^{-2} \mathrm{ft} / \mathrm{d}$ to $7.8 \times 10^{-7}$ $\mathrm{ft} / \mathrm{d}$. Planert and Aucott (1985, p. 43) reported that, in the Osceola County area, tests of the shallow aquifer indicated a value of $5 \times 10^{-3} \mathrm{ft} / \mathrm{d}$ for the vertical hydraulic conductivity of the confining unit. Tibbals (1990, fig. 30$)$ reported simulated leakage coefficients of $5 \times 10^{-5}$ to $3 \times 10^{-4}$ per day for extreme northwest and southwest Osceola County. In extreme eastern Osceola County, a value of $1 \times 10^{-6}$ to $1 \times 10^{-5}$ per day was reported. In the remainder of the county simulated leakage coefficients were reported as $1 \times 10^{-5}$ to $5 \times 10^{-5}$ per day.
Recharge to the intermediate confining unit is by downward leakage from the overlying surficial aquifer system where the water table stands above the head in the confining unit, and by upward leakage from the underlying Upper Floridan aquifer where the head of the Upper Floridan is above that in the confining unit. Some recharge from surrounding counties probably occurs as lateral inflow within the unit. Discharge from the intermediate confining unit is by downward leakage to the Upper Floridan aquifer, upward leakage to the surficial aquifer, lateral outflow from the county, and pumping.

The water level record for well 37 , completed in the intermediate confining unit, is shown in figure 25 . The well is located within a recharge area of the Floridan aquifer system. The water level in the well has been as much as $14 \mathrm{ft}$ 

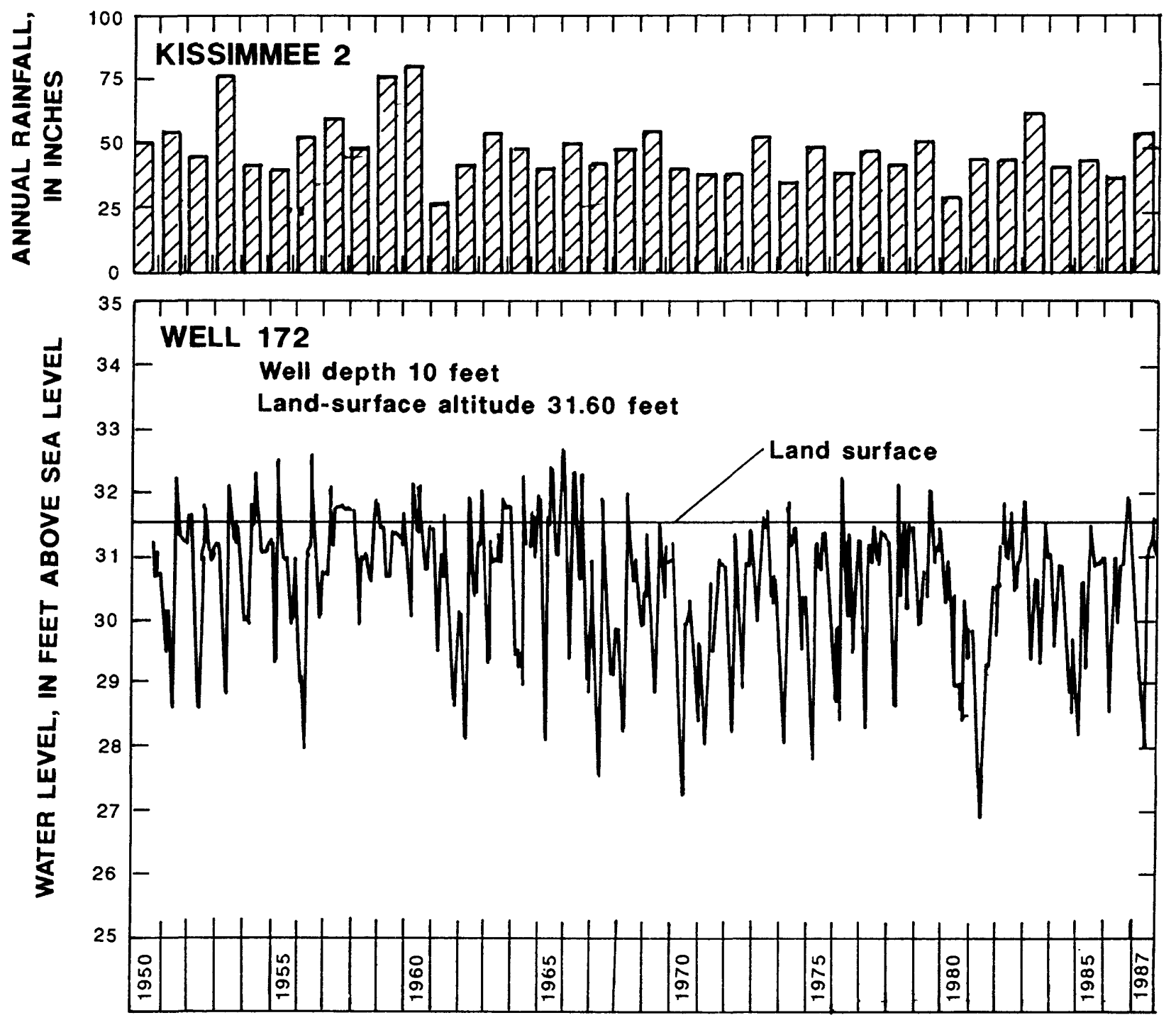

Figure 21. Water level in well 172, and annual rainfall at Kissimmee, 1950-87.

above the potentiometric surface of the Floridan aquifer system, but remains below land surface. To the east, in the discharge area of the Floridan aquifer system, wells in the intermediate confining unit commonly flow. The hydrograph of well 37 indicates a trend of rising water level since 1976. The nearest observation wells completed in the Floridan aquifer system and in the surficial aquifer system (about 5 to 6 mi distant) do not indicate a similar trend. However, surficial aquifer system well 132 , about $24 \mathrm{mi}$ north, has a very similar trend. The reason for the upward trend in well 37 is unknown, but may be indicative of decreasing withdrawals from nearby wells completed in the intermediate confining unit or recharge from return of irrigation water pumped from Floridan aquifer system wells.

Little water-quality data are available for wells completed in the intermediate confining unit because there are relatively few such wells in Osceola County. The quality of water in the confining unit is related to location, depth, and local hydrology. Where downward leakage to the confining unit from the surficial aquifer system occurs, the water quality tends to be similar to that of the surficial aquifer system. Where upward leakage from the Upper Floridan aquifer occurs, water in the intermediate confining unit tends to be similar in quality to the Upper Floridan. In the areas of the Floridan aquifer system where an upward hydraulic gradient exists, chloride and sulfate concentrations in the Floridan tend to be relatively high. There, water in the intermediate confining unit is generally of better quality, and thus, is often used for domestic and small stock supplies. The better-quality water is probably due to the absence, or near absence, of upward leakage because of tight, dense layers within the confining unit. An analysis of water from well 37, in an area of downward leakage, and from a report by Herr and Shaw $(1989$, p. $81-83)$, is presented as follows. 


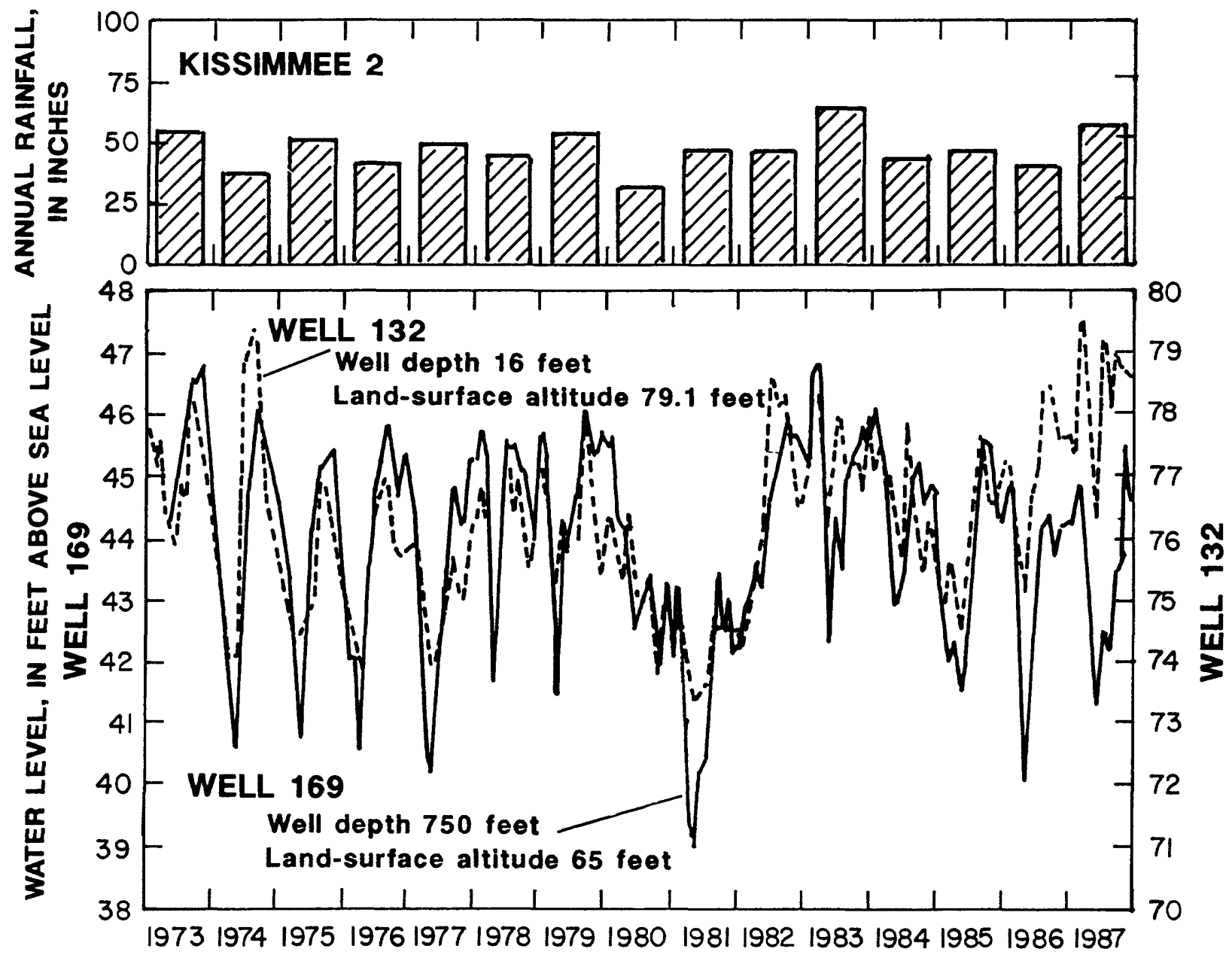

Figure 22. Water levels in wells 132 and 169, and annual rainfall at Kissimmee, 1973-87.

$\begin{array}{lc}\text { Date of sample } & 6-24-87 \\ \text { Depth of well }(\text { feet }) & 310 \\ \text { Temperature }{ }^{\circ} \mathrm{C} & 25.2 \\ \text { Specific conductance }(\mu \mathrm{S} / \mathrm{cm}) & 543 \\ \text { pH } & 7.8 \\ \text { Alkalinity }\left(\mathrm{mg} / \mathrm{L} \text { as } \mathrm{CaCO}_{3}\right) & 205 \\ \text { Nitrogen, nitrite total }(\mathrm{mg} / \mathrm{L}) & .004 \\ \text { Nitrogen, nitrate total }(\mathrm{mg} / \mathrm{L}) & .014 \\ \text { Ammonia, dissolved }(\mathrm{mg} / \mathrm{L}) & .97 \\ \text { Orthophosphate }(\mathrm{mg} / \mathrm{L}) & .004 \\ \text { Calcium, dissolved }(\mathrm{mg} / \mathrm{L}) & 67.2 \\ \text { Magnesium, dissolved }(\mathrm{mg} / \mathrm{L}) & 4.98 \\ \text { Sodium, dissolved }(\mathrm{mg} / \mathrm{L}) & 41.8 \\ \text { Potassium, dissolved }(\mathrm{mg} / \mathrm{L}) & 1.56 \\ \text { Chloride, dissolved }(\mathrm{mg} / \mathrm{L}) & 53.1 \\ \text { Sulfate, dissolved }(\mathrm{mg} / \mathrm{L}) & 5.0 \\ \text { Fluoride, dissolved }(\mathrm{mg} / \mathrm{L}) & .55 \\ \text { Silica, dissolved }(\mathrm{mg} / \mathrm{L} \text { as SiO} & 2) \\ \text { Arsenic, total }(\mu \mathrm{g} / \mathrm{L}) & 21.7 \\ \text { Chromium, total }(\mu \mathrm{g} / \mathrm{L}) & 1.60 \\ \text { Copper, total }(\mu \mathrm{g} / \mathrm{L}) & 1.42 \\ \text { Manganese, total }(\mu \mathrm{g} / \mathrm{L}) & 22.33 \\ \text { Lead, total }(\mu \mathrm{g} / \mathrm{L}) & 94.45 \\ \text { Iron, dissolved }(\mu \mathrm{g} / \mathrm{L}) & 81.45 \\ \text { Strontium, dissolved }(\mu \mathrm{g} / \mathrm{L}) & 200 \\ \text { Zinc, total }(\mu \mathrm{g} / \mathrm{L}) & 4.76 \\ \text { Solids, residue at } 180^{\circ} \mathrm{C}(\mu \mathrm{g} / \mathrm{L}) & 87 \\ & 314\end{array}$

\section{GEOHYDROLOGY OF THE FLORIDAN AQUIFER SYSTEM}

The Floridan aquifer system in Osceola County consists of limestone and dolomite, ranging from about 2,400 $\mathrm{ft}$ in thickness in the northwestern corner of the county to $2,900 \mathrm{ft}$ in the southeastern part of the county (fig. 26). Though the Floridan aquifer system is reported to generally cross formation and age boundaries, Miller (1986, p. B46) reported that, regionally, the top of the system is the Suwannee Limestone, but if the Suwannee is absent, the Ocala Limestone is the top. In Osceola County, the Suwannee Limestone appears to be missing (figs. 8, 9, and 10 ), and if present, probably is thin and patchy. Also, the Ocala Limestone is missing in some areas of the northwestern and north-central part of the county. Accordingly, in Osceola County, the Floridan aquifer system consists of the Ocala Limestone (where present), Avon Park Formation, Oldsmar Formation, and the upper part of the Cedar Keys Formation (Miller, 1986, p. B46). The lower part of the Avon Park Formation was formerly known as the Lake City Limestone, but Miller (1986, p. B26) abandoned the Lake City Limestone 


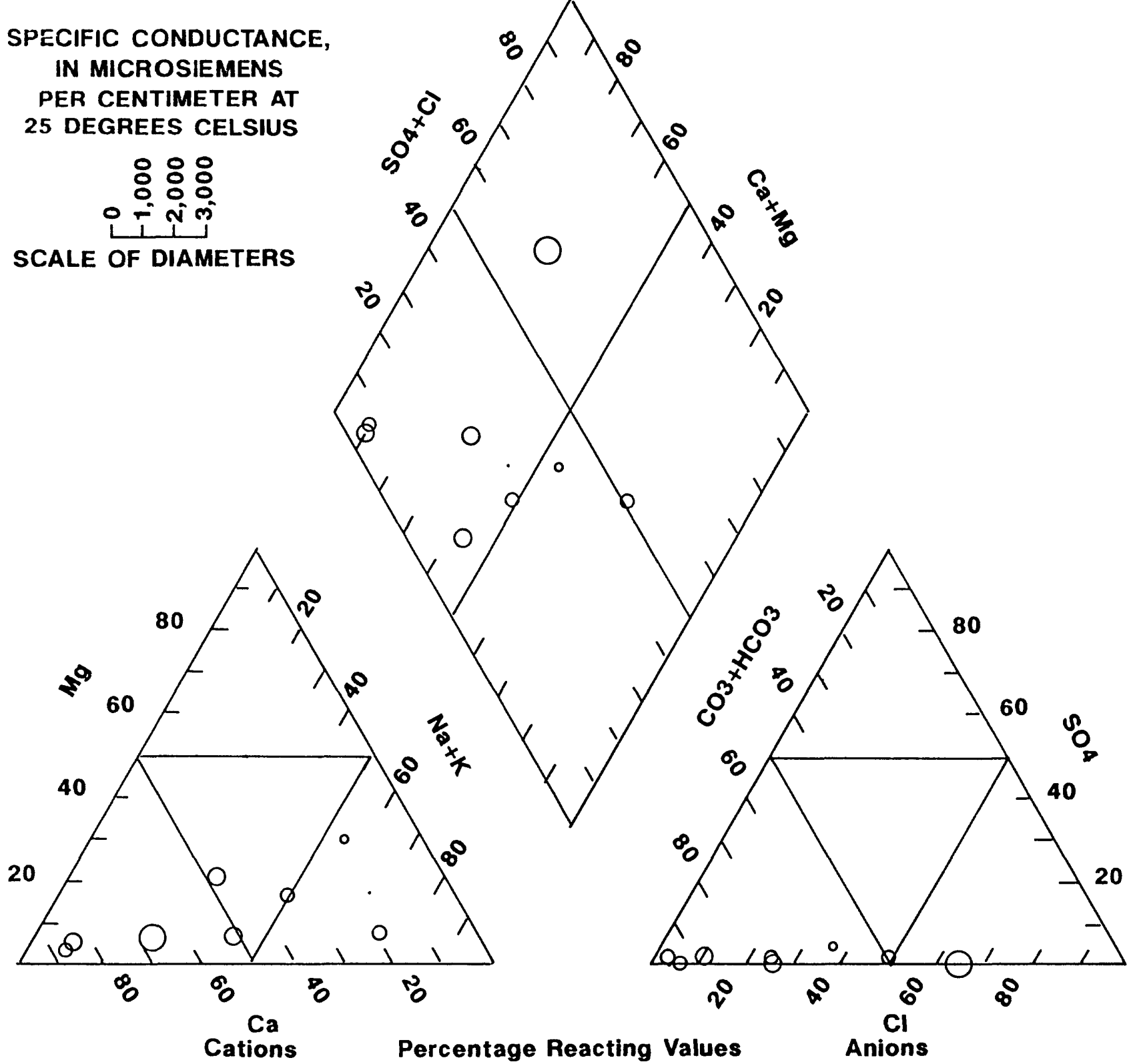

Figure 23. Major dissolved-constituent ratios in water from wells completed in the surficial aquifer system.

as a distinct formation. Because of sparse control and the interfingering of key marker beds, the base of the Floridan aquifer system is difficult to ascertain. Four oil test wells drilled to basement rock are the only wells known to penetrate below the Avon Park Formation in Osceola County.

The top of the Upper Floridan aquifer is also the top of the Floridan aquifer system (fig. 27). The aquifer is about $300 \mathrm{ft}$ thick throughout most of the county, except for the eastern part of the county where the unit thickens to about $350 \mathrm{ft}$. The top slopes generally to the southeast, and ranges in altitude from sea level to about $-275 \mathrm{ft}$. The surface is irregular and is apparently paleokarstic. Deep, sinkhole-type depressions in the surface commonly extend to as much as $200 \mathrm{ft}$ below the surrounding top surface (fig. 27).
The base of the Upper Floridan aquifer is troughlike in Osceola County, and ranges in altitude from about $-350 \mathrm{ft}$ in northwestern Osceola County to about $-650 \mathrm{ft}$ in southeastern Osceola. The base in the northeastern part of the county is about $-650 \mathrm{ft}$ and in the southwestern part about $-600 \mathrm{ft}$.

Data on the middle semiconfining unit are scarce. The unit (unit 1 of Miller, 1986, p. B56) is one of eight lowpermeability units of variable subregional extent and thickness that lie within the Floridan aquifer system. According to Miller (1986, p. B55), the middle semiconfining unit consists mostly of low-permeability strata that contains a few highpermeability zones. These zones may differ from the Upper and Lower Floridan aquifer in hydraulic head, water quality, and response to natural and pumping stresses. 
Table 2. Representative analyses and ranges in concentrations of constituents in water from wells completed in the surficial aquifer system

[Concentrations in milligrams per liter unless otherwise noted; $\mu \mathrm{g} / \mathrm{L}$, micrograms per liter; $\mu \mathrm{S} / \mathrm{cm}$, microsiemens per centimeter at $25{ }^{\circ} \mathrm{C} ;--$, no data]

\begin{tabular}{lcccccccccc}
\hline Well & $\begin{array}{c}\text { Depth } \\
\text { Neet) }\end{array}$ & $\begin{array}{c}\text { Specific } \\
\text { conductance } \\
(\mu \mathrm{S} / \mathrm{cm})\end{array}$ & Calcium & Magnesium & Sodium & Potassium & Alkalinity & $\begin{array}{c}\text { Chloride } \\
(250)^{1}\end{array}$ & $\begin{array}{c}\text { Sulfate } \\
(250)^{1}\end{array}$ & $\begin{array}{c}\text { Hardness } \\
(\mu \mathrm{g} / \mathrm{L}) \\
(300)^{1}\end{array}$ \\
\hline
\end{tabular}

$\begin{array}{rrrcr}4 & 9 & 64 & 1.8 & 1.7 \\ 14 & 100 & 421 & 81 & 2 . \\ 18 & 7 & 588 & 9.3 & 7 . \\ 21 & 23 & 237 & 3.6 & 3.9 \\ 26 & 117 & 602 & 60 & 16 \\ 38 & 28 & 623 & 101 & 2.8 \\ 63 & 33 & 392 & 27 & 7.7 \\ 65 & 130 & 531 & 105 & 4 . \\ 77 & 64 & 447 & 17 & 4.0 \\ 96 & 18 & -- & 4.4 & 1 . \\ 122 & 65 & 72 & 1.9 & 1 . \\ 173 & 16 & 795 & 100 & 5 . \\ 175 & 8 & 157 & 7.6 & 2.9\end{array}$

$\begin{array}{crrc}1.6 & 0.1 & 9 & 2.4 \\ 8.3 & .8 & 208 & 9.8 \\ 28 & 9.2 & 206 & 30 \\ 12 & 2.4 & 34 & 15 \\ 44 & 2.3 & 228 & 57 \\ 32 & 1.6 & 334 & 29 \\ 40 & 3.2 & 137 & 33 \\ 12 & .1 & 312 & 7.1 \\ 69 & 3.2 & 98 & 71 \\ 7.3 & 1.3 & 35 & 20 \\ 7.7 & .6 & 4 & 13 \\ 41 & 1.0 & 128 & 170 \\ 10 & 1.1 & 30 & 29\end{array}$

$\begin{array}{crr}4.1 & -- & 390 \\ .4 & 210 & 100 \\ 14 & -- & 2,850 \\ 5.2 & -- & 25,300 \\ 2.0 & 220 & 250 \\ 5.0 & -- & 510 \\ 4.0 & -- & 50 \\ 5.0 & -- & 60 \\ 3.6 & 59 & 210 \\ 15 & -- & 120 \\ .4 & 9 & 840 \\ .0 & 270 & -- \\ 11 & - & 270\end{array}$

Ranges in concentrations

\begin{tabular}{|c|c|c|c|c|c|c|c|c|c|c|}
\hline Range & & & & & & & & & & \\
\hline Low & 64 & 1,8 & 1.1 & 1.6 & .1 & 4 & 2.4 & .0 & 9 & 50 \\
\hline High & 623 & 105 & 16 & 69 & 9.2 & 334 & 170 & 130 & 270 & 25,300 \\
\hline
\end{tabular}

\footnotetext{
${ }^{1}$ Numbers in parentheses under constituent identifiers are secondary standards for drinking water established by the Florida Department of Environmental Regulation (1989).
}

For this study, the middle semiconfining unit is identified as a dolomitic zone of variable thickness that generally is near the middle of the Avon Park Formation. Well data indicate the middle semiconfining unit in Osceola County commonly contains productive water-bearing zones that are variable in thickness, extent, number, and altitude. Geophysical logs indicate that the first occurring water-bearing zones within the unit are located about 100 to $200 \mathrm{ft}$ below its top. The logs also indicate that the top of the unit ranges in altitude from about -300 to $-600 \mathrm{ft}$. Miller (1986, fig. 11) indicates that the middle semiconfining unit in Osceola County ranges from about $450 \mathrm{ft}$ in thickness in the northwestern and southeastern corners of the county to a $700 \mathrm{ft}$ thickness in the northern and west-central part of the county.

According to Miller (1986, p. B65), the Lower Floridan aquifer consists of a thick sequence of largely lowpermeability carbonate rocks separated by relatively thin permeable zones that lie between the middle semiconfining unit and the sub-Floridan confining unit (Southeastern Geological Society Ad Hoc Committee on Florida Hydrostratigraphic Unit Definition, 1986, p. 7). Little information is available on the thickness of the Lower Floridan aquifer. Miller (1986, pl. 32) indicates that the Lower Floridan aquifer in Osceola County is about $1,400 \mathrm{ft}$ thick in the northwestern part of the county and thickens to about $2,100 \mathrm{ft}$ in the west-central part of the county. In the eastern part of the county, the Lower Floridan aquifer ranges in thickness from about $1,500 \mathrm{ft}$ north to $1,900 \mathrm{ft}$ south. According to Miller (1986, pl. 33), the base of the Lower Floridan aquifer (fig. 28) slopes southeast from an altitude of about $-2,400 \mathrm{ft}$ in the northern part of the county to $-3,200 \mathrm{ft}$ near the center in the county. From there, the base of the Lower Floridan rises to an altitude of about $-3,100 \mathrm{ft}$ in the southern part.

The Boulder Zone (Kohout, 1965) is a unique zone near the base of the Lower Floridan aquifer. It consists of highly permeable, fractured, and cavernous dolomite about 500 to $800 \mathrm{ft}$ thick that is commonly found at depths of about 2,500 to 3,000 $\mathrm{ft}$ in south Florida (Miller, 1986, p. B68). Miller (1986, fig. 23) indicates the zone is present only in the extreme southeastern corner of Osceola County. Its top ranges in altitude from about $-2,300$ to $-2,600 \mathrm{ft}$.

The sub-Floridan confining unit is the lower confining unit (Miller 1986, p. 46). It consists of a massively bedded anhydrite of extremely low permeability that is in the upper part of the Cedar Keys Formation (Miller, 1986, p. B46).

\section{Hydraulic Properties}

The hydraulic properties of the middle semiconfining unit and the Lower Floridan aquifer of the Floridan aquifer system are not well known, so most discussion of hydraulics within the system relates to the better-known hydraulic characteristics of the Upper Floridan aquifer. Variations in 


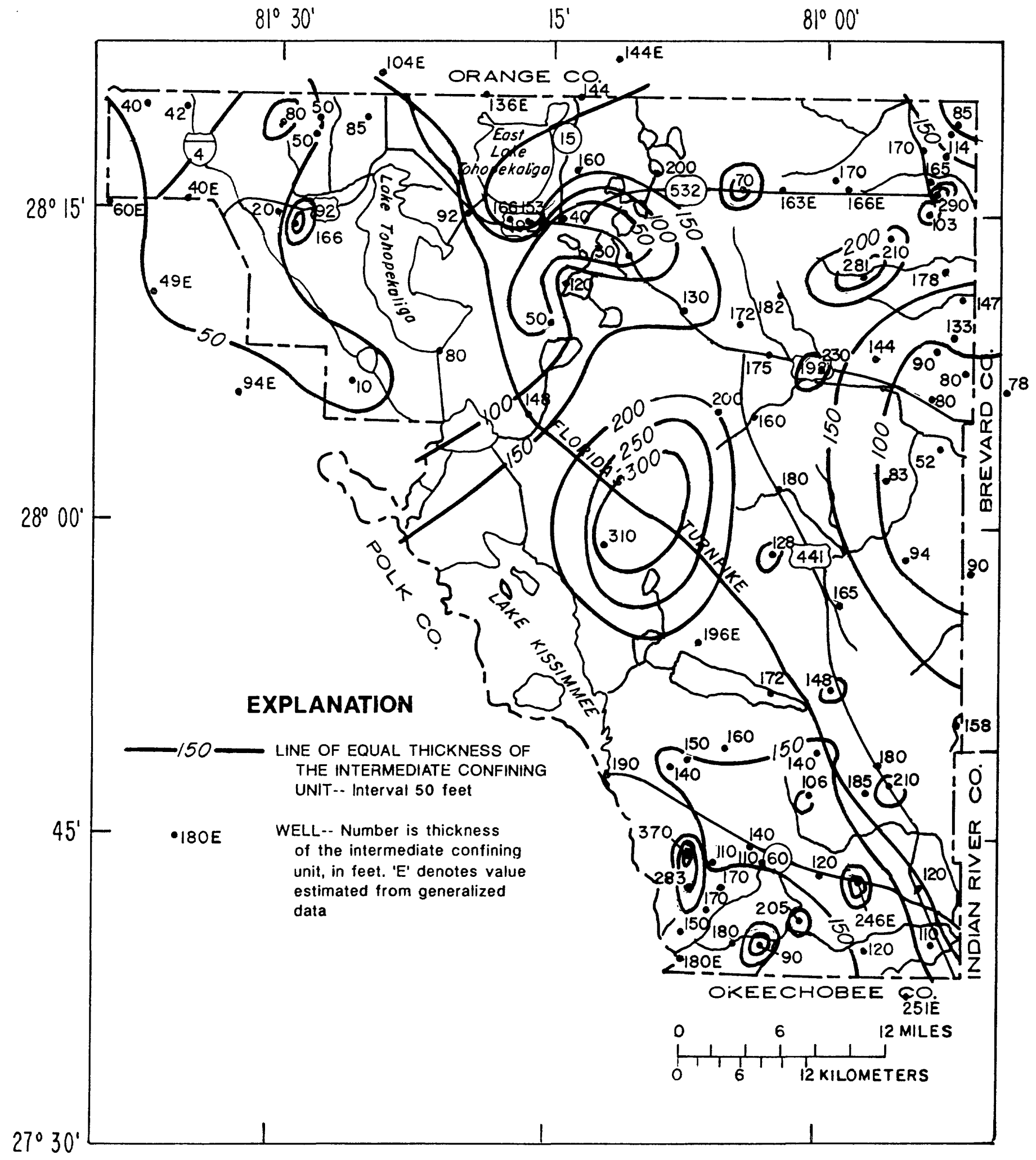

Figure 24. Thickness of the intermediate confining unit (Hawthorn Formation). 


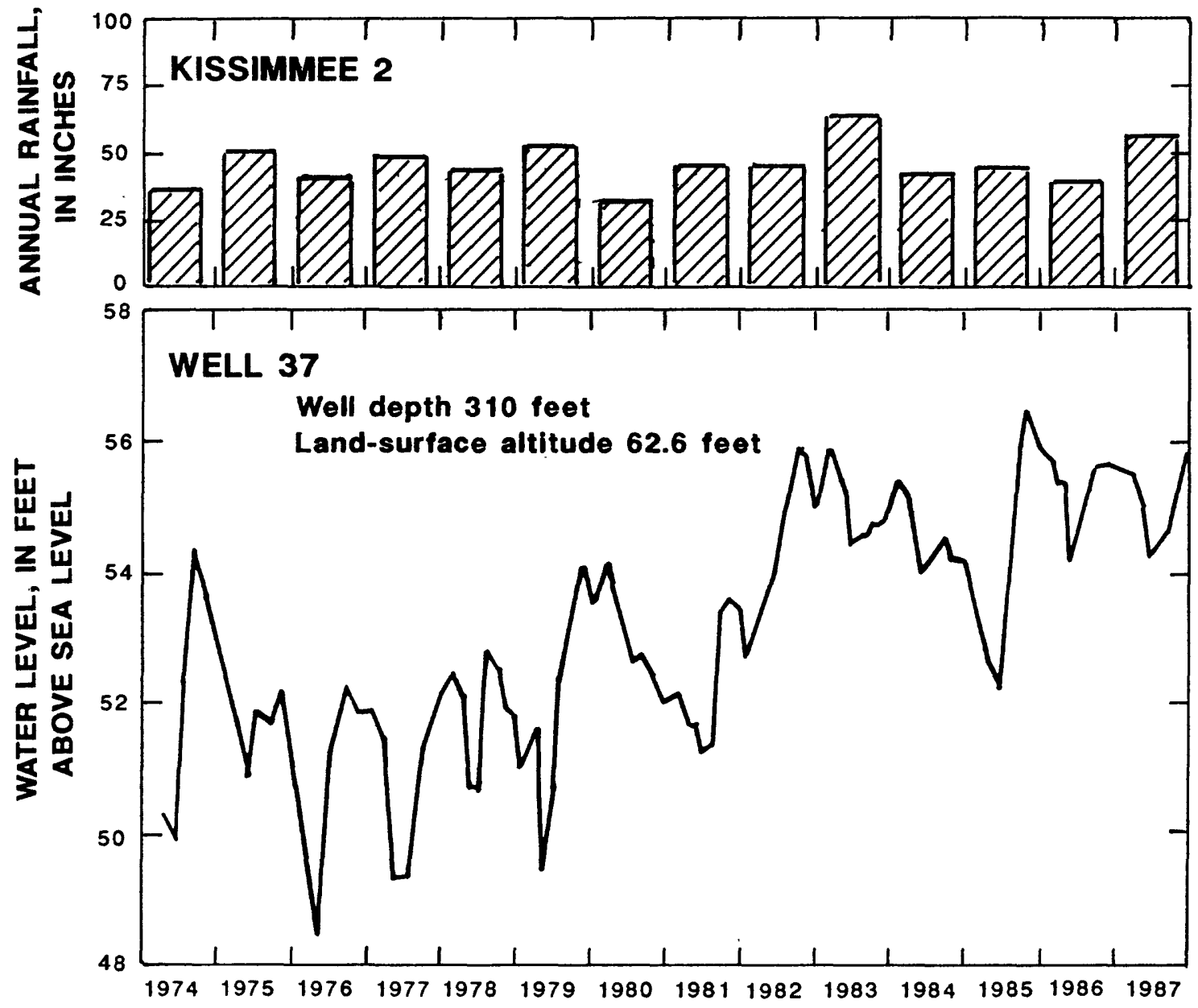

Figure 25. Water level in well 37 and annual rainfall at Kissimmee 1974-87.

the hydraulic characteristics of the rock strata within the Floridan aquifer system are complex and are closely related to the geologic framework of the system. The porosity and permeability of the rock strata that comprise the system result from combinations of (1) the original texture of the rock; (2) processes that have acted on the rock, such as dolomitization and recrystallization; (3) joints, fractures, and faults; and (4) mineral dissolution or precipitation. Movement of water throughout the Floridan aquifer system is mostly through networks of many small solution openings along joints or bedding planes. In places, flow may be through large cavernous features of the paleokarst. Most of the hydraulic (and water-quality) variations that occur in the Floridan aquifer system in Osceola County probably result from a combination of several of the above-mentioned factors. The combinations that are in effect may cause considerable variation of yield and water quality in wells in close proximity and at equal depth. Analysis of borehole geophysical data indicate that water-yielding zones within a borehole are typically discrete and may occur at different depths in proximate boreholes. However, some boreholes may contribute water throughout their open interval.
The permeability of the Upper Floridan aquifer is reported to be generally higher than that of the Lower Floridan (Miller, 1986, p. B54). The most productive wateryielding zones are probably in the Ocala Limestone and the upper part of the Avon Park Formation. The rate of groundwater circulation is relatively high in the Upper Floridan aquifer compared to circulation in the Lower Floridan aquifer, but some wells that penetrate the middle semiconfining unit may obtain much of their yield from that unit. Where the top of the Upper Floridan aquifer is at least about $200 \mathrm{ft}$ below sea level, wells greater than about $700 \mathrm{ft}$ in depth probably penetrate through the Upper Floridan aquifer and are completed in the middle semiconfining unit. Wells more than about 1,200 to $1,300 \mathrm{ft}$ deep probably penetrate through the Upper Floridan aquifer, the middle semiconfining unit, and are completed in the Lower Floridan aquifer. These deeper wells were probably drilled in the Lower Floridan aquifer because in places the Upper Floridan and the middle semiconfining unit could not supply sufficient water for a particular need.

Yields of wells that tap the Floridan aquifer system can be related to the specific capacity of the well and in an 


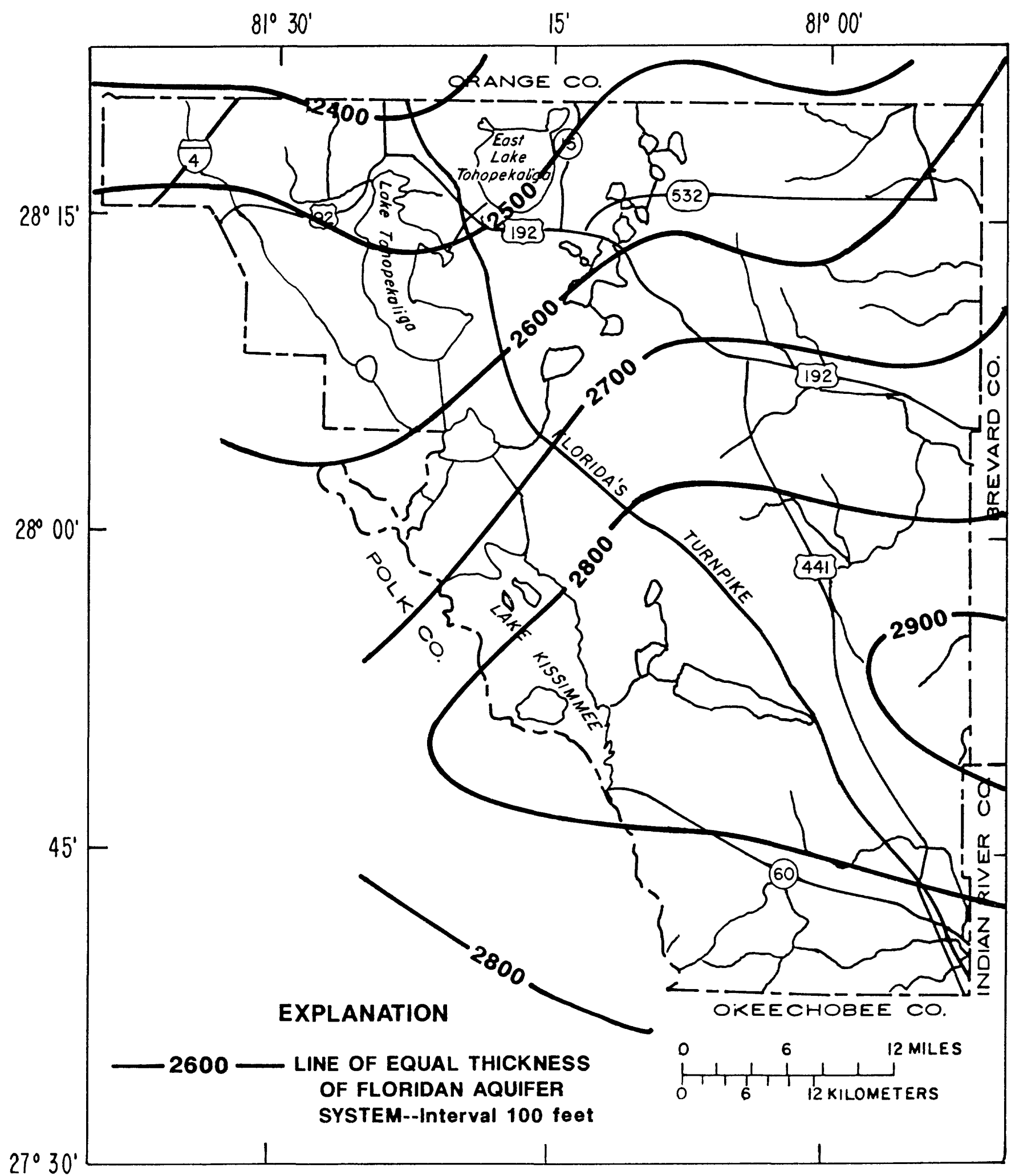

Figure 26. Thickness of the Floridan aquifer system. 


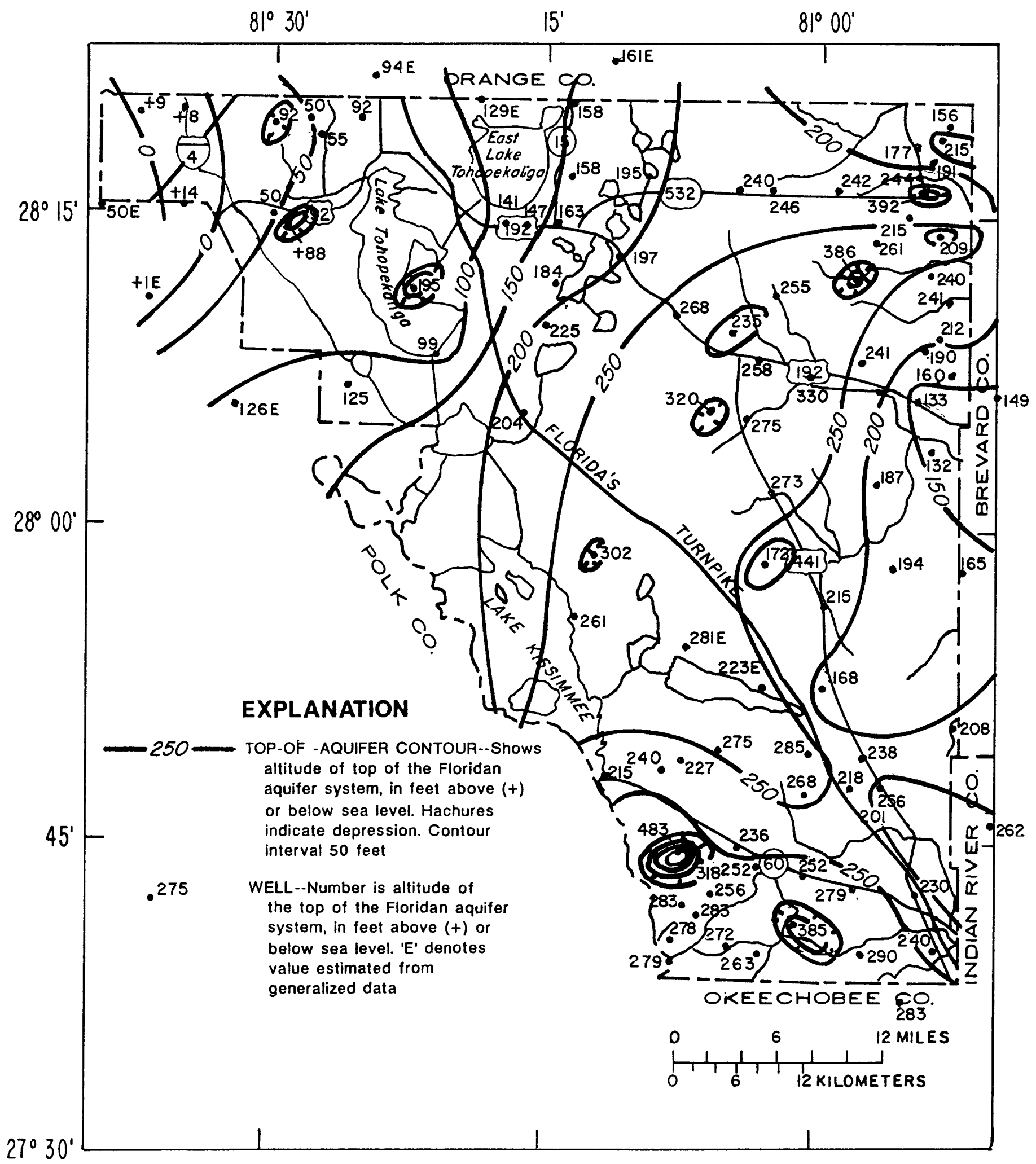

Figure 27. Altitude of the top of the Floridan aquifer system. 


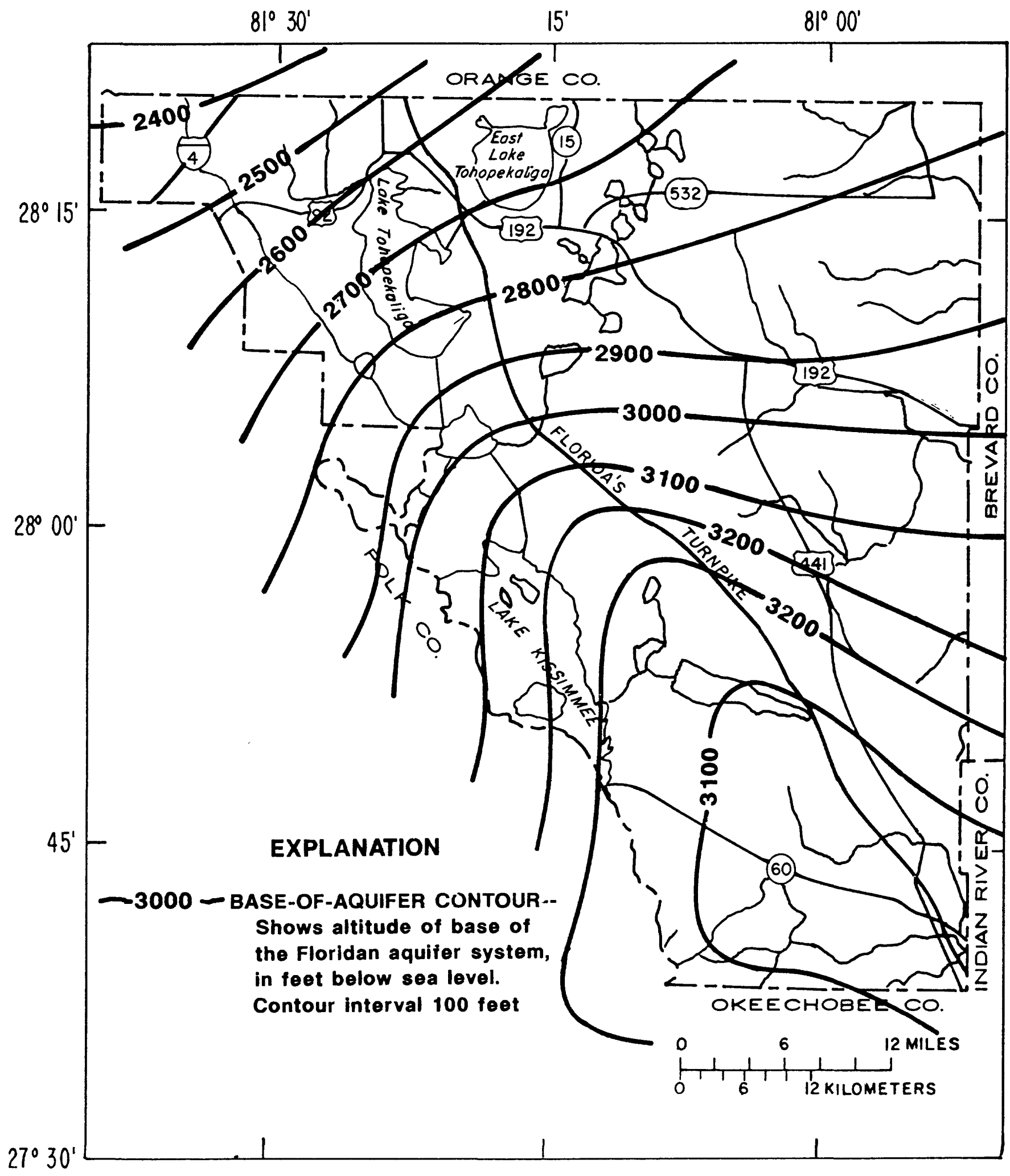

Figure 28. Altitude of the base of the Floridan aquifer system (adapted from Miller, 1986). 
approximate manner, to the transmissivity of the rock section open to the well. Aquifer tests to determine specific capacity or transmissivity values in the Floridan aquifer system are often complicated by large permeability differences within the tested aquifer section and by complex boundary conditions. Other major factors such as anisotropy and partial penetration of the aquifer may further complicate a test analysis. Few wells were available for testing to determine transmissivity directly. Most wells were equipped with pumps connected to closed water systems that prevent measurement of flow rates or heads.

Estimates of transmissivity by previous investigators in Osceola County have been based mostly on specific capacity tests (Planert and Aucott, 1985, p. 15), after a method by Brown (1963, p. 336-338). Transmissivity values of two wells in Osceola County and one well near its southwestern border in Polk County, obtained from recovery tests made by personnel of the South Florida Water Management District, were 5,600 (well 24), 8,900 (well 3), and 43,000 (well 112) $\left[\left(\mathrm{ft}^{3} / \mathrm{d}\right) / \mathrm{ft}^{2}\right] \mathrm{ft}$ (Shaw and Trost, 1984a, table 20). The wells completely penetrate the Upper Floridan aquifer and terminate in the middle semiconfining unit (see fig. 29 for locations). Tibbals (1981, fig. 6) determined a modelderived transmissivity range of 100,000 to 200,000 $\left[\left(\mathrm{ft}^{3} / \mathrm{d}\right) / \mathrm{ft}^{2}\right] \mathrm{ft}$ for the Upper Floridan aquifer in most of Osceola County, except for the northwestern area where transmissivities ranged from 10,000 to $35,000\left[\left(\mathrm{ft}^{3} / \mathrm{d}\right) / \mathrm{ft}^{2}\right] \mathrm{ft}$. An estimated transmissivity of $60,000\left[\left(\mathrm{ft}^{3} / \mathrm{d}\right) / \mathrm{ft}^{2}\right] \mathrm{ft}$ was obtained for the Lower Floridan aquifer for most of the county (Tibbals, 1981, fig. 7).

In a ground-water flow study by Planert and Aucott (1985, p.47), northwestern Osceola was assigned a range of transmissivity of 6,500 to $65,000\left[\left(\mathrm{ft}^{3} / \mathrm{d}\right) / \mathrm{ft}^{2}\right] \mathrm{ft}$ for the Upper Floridan aquifer and $6,500\left[\left(\mathrm{ft}^{3} / \mathrm{d}\right) / \mathrm{ft}^{2}\right] \mathrm{ft}$ for the Lower Floridan. Both the Upper and Lower Floridan aquifers were assigned a transmissivity value of $65,000\left[\left(\mathrm{ft}^{3} / \mathrm{d}\right) / \mathrm{ft}^{2}\right] \mathrm{ft}$ in the remainder of the county. Planert and Aucott (1985, p. 67) also reported that the transmissivity of the Upper Floridan aquifer increases to the north and west of Holopaw.

Bush and Johnston (1988, p. C20) reported that confined areas of the Upper Floridan aquifer (where the intermediate confining unit is greater than $100 \mathrm{ft}$ thick and unbreached) generally have lower transmissivity than semiconfined areas (where the intermediate confining unit is less than $100 \mathrm{ft}$ thick, breached, or both). Based on nearby aquifer tests, geology, and simulation, Bush and Johnston (1988, pl. 2) estimated a range in transmissivity of less than 10,000 to $50,000\left[\left(\mathrm{ft}^{3} / \mathrm{d}\right) / \mathrm{ft}^{2}\right] \mathrm{ft}$ for the Upper Floridan aquifer in northwestern Osceola County, and a range of 100,000 to $250,000\left[\left(\mathrm{ft}^{3} / \mathrm{d}\right) / \mathrm{ft}^{2}\right] \mathrm{ft}$ for the remainder of the county. Based on aquifer tests in Orange County, a storage coefficient of about $1 \times 10^{-4}$ to $1 \times 10^{-5}$ is estimated for the Upper Floridan aquifer in most of Osceola County (Bush and Johnston, 1988, table 2).
Miller (1986, p. B68) reported that the transmissivity of the entire thickness of the Boulder zone (near the base of the Lower Floridan aquifer) may exceed $10^{7}\left[\left(\mathrm{ft}^{3} / \mathrm{d}\right) / \mathrm{ft}^{2}\right] \mathrm{ft}$. The zone contains saline water and is widely used as a receiving zone for municipal and other liquid wastes along the southeast coast of Florida.

Specific capacity data are more easily obtained in the field than transmissivity data and therefore are more abundant. Several methods are used to estimate transmissivity values from specific capacity. However, Bush and Johnston (1988, p. C18) reported that specific-capacity data are not a good basis from which to estimate transmissivity in most parts of the Floridan aquifer system. They concluded that specific capacities are a function of not only the size and spacing of water-bearing openings in the rock adjacent to the well bore, but also well losses due to turbulent flow within the well bore or immediately adjacent to it. Most values of transmissivity calculated from specific-capacity data are much lower than values required to properly calibrate digital models.

For purposes of comparing values of specific capacity, an adjustment can be made to the specific capacity value by dividing it by depth of well penetration into the aquifer. However, Bush and Johnston $(1988$, p. C18,19) suggest that, because the uppermost part of the Floridan aquifer system generally is the most transmissive, especially where the aquifer is semiconfined and karstic, that comparing specific capacity per foot of penetration of shallow wells with specific-capacity data for deep wells can have little meaning. For example, tests run at the Bull Creek site (fig. 29) by the St. Johns River Water Management District indicate that the specific capacity of a 780-ft-deep well was about one-fourth the specific capacity of a 400-ft-deep well (5.0 and 20.3 (gal/min)/ft, respectively). Even though the range of values of specific capacities of wells in the Floridan aquifer system is large and shows little areal pattern, if the above-mentioned constraints are considered, approximate comparisons can be made and used as a general indicator of well productivity. Specific capacities of 27 wells in Osceola County for which data are available range from 5 to $510(\mathrm{gal} / \mathrm{min}) / \mathrm{ft}$ with a median of $57(\mathrm{gal} / \mathrm{min}) / \mathrm{ft}$ (table 3). Reported specificcapacity data from the St. Johns River Water Management District, based on tests made on six wells at the Bull Creek site (fig. 28), ranged from 4.7 to $20.3(\mathrm{gal} / \mathrm{min}) / \mathrm{ft}$ and averaged $8.8(\mathrm{gal} / \mathrm{min}) / \mathrm{ft}$.

The variability of specific capacity of wells completed in the Floridan aquifer system is further illustrated by comparing data for wells $186(1,195 \mathrm{ft}$ deep) and $187(458 \mathrm{ft}$ deep). These two wells are about $1,500 \mathrm{ft}$ apart, similar in diameter, tested at the same pumping rate, but completed at different depths. Well 186 penetrates $912 \mathrm{ft}$ and well 187 penetrates only $180 \mathrm{ft}$ of the Floridan aquifer system, but the reported specific capacity of the shallow penetrating well is nearly double that of the deeper well (279 and 140 (gal/min)/ft, respectively; table 3). 
Well casings generally extend only deep enough to allow the well bore to remain open, usually into the intermediate confining unit (the Hawthorn Formation). Because in most places the total thickness of the surficial aquifer system and the intermediate confining unit exceeds $100 \mathrm{ft}$, the bottom 400 to $600 \mathrm{ft}$ of many wells more than about $500 \mathrm{ft}$ deep (those completed in the Floridan aquifer system) are frequently "open hole," or uncased. Casing diameters range from 2 to 24 inches. Wells used for large irrigation projects and public-supply wells generally are 8 to 12 in. in diameter. Casings are made of steel, black iron, or plastic. Corrosion of metal well casings has caused many older wells to fail, so the use of polyvinyl chloride (PVC) plastic casing has become more prevalent in recent years. Burns (1983, p. 30) reported that in Lee County (southwest Florida) the life expectancy of steel-cased wells is 20 to 25 years, and that saturation and stability indices indicate that the corrosion of steel casing is most intensive in the surficial aquifer system. As mentioned previously, a leaky well casing could cause intrusion of water from the Floridan aquifer system into the surficial aquifer system in discharge areas of the Floridan.

\section{Potentiometric Surface}

The regional configurations of the potentiometric surface of the Upper Floridan aquifer in Osceola County for May 1981 (reflecting the 1980-81 drought) and May 1987 (reflecting above-average rainfall in early 1987) are shown in figures 30 and 31. Direction of lateral ground-water movement in the Upper Floridan aquifer in the county generally is eastward. Hydrographs of six wells (see fig. 32 for well locations) used in the compilation of biannual potentiometric surface maps, show the fluctuations of the water levels and the easterly trend of the lateral hydraulic gradient (fig. 33).

The potentiometric surface of the Upper Floridan aquifer fluctuates in response to changes in recharge and discharge. The major components that cause potentiometric-surface fluctuations are related to rainfall and pumping. Generally, short-term components (recharge from convective storms, for example) are superimposed on long-term conditions in the potentiometric surface of the Upper Floridan aquifer (fig. 33). Pumpage and rainfall can cause long- or short-term changes in the potentiometric surface, depending on duration and intensity.

In the recharge area of the Floridan aquifer system in Osceola County, September normally is the last month of the wet season and May is the last month of the dry season. Generally, the Upper Floridan aquifer is most stressed in May, because by then the dry season (low rainfall) has lasted for about 7 months and pumping for agricultural irrigation and public-supply withdrawals are heaviest. The potentiometric surface in May generally ranges in altitude from about $120 \mathrm{ft}$ on the Lake Wales Ridge in northwestern Osceola County to about 35 to $40 \mathrm{ft}$ along the eastern county boundary (fig. 31). The mound shown on the potentiometric surface of May 1987 (fig. 31), in southeastern Osceola County, may reflect local recharge to the Floridan. Comparison of the May 1981 and May 1987 potentiometric-surface maps show that the potentiometric surface was about $5 \mathrm{ft}$ lower in May 1981 than in May 1987. In Osceola County, potentiometric contours generally are shifted slightly eastward in September relative to May because of the recharge from summer (wet season) rains and the associated reduction of public supply and irrigation pumping.

\section{Water Levels}

Heads in the Floridan aquifer system typically increase with depth of penetration in discharge areas and decrease with depth in recharge areas, but data are not available to quantify these head differences for the Floridan aquifer system in Osceola County. Schiner and others (1988, p. 64) reported that, during December 1980, in a discharge area of the Floridan in adjacent Indian River County, the water level of a well $901 \mathrm{ft}$ deep was $3.5 \mathrm{ft}$ higher than the level in a nearby well $740 \mathrm{ft}$ deep.

Water levels in wells cased into the middle semiconfining unit and the Lower Floridan aquifer, to depths of about 1,000 $\mathrm{ft}$ or more, probably differ in altitude from the levels in wells cased into the Upper Floridan aquifer. However, most wells that are completed in the units that underlie the Upper Floridan aquifer penetrate several producing zones having unique water levels. But these wells generally are only cased into the intermediate confining unit; thus, water levels in the wells reflect some combination of heads of the different producing zones. Several reports on test wells in northern Osceola County that penetrate both the Upper and Lower Floridan indicate little difference in head (or water quality) between the two units, indicating that combination water levels, and not unique water levels, were observed.

The hydrograph of well 169 (fig. 22) illustrates waterlevel fluctuations in a recharge area of the Floridan aquifer system little affected by pumping, whereas the hydrograph of well 186 (fig. 34) illustrates fluctuations of water level in a well affected by pumping (see fig. 32 for locations). The hydrograph of well 113 (fig. 35) shows detailed (daily) water-level fluctuations of a well that taps both the Upper Floridan aquifer and the middle semiconfining unit from April 1987 to March 1988 and from May 1988 to May 1989. A comparison of the hydrographs and analysis of water-level data collected for compilation of biannual potentiometricsurface maps (fig. 33) show that September water levels generally range from 2 to $5 \mathrm{ft}$ higher than May levels. However, in heavily pumped areas, water levels can decline as much as $10 \mathrm{ft}$ between September and May if rainfall is deficient. Water levels in many wells in the county declined to record lows in May 1981 (fig. 33). The rainfall deficiency of about $23 \mathrm{in}$. from the yearly average at Kissimmee during 


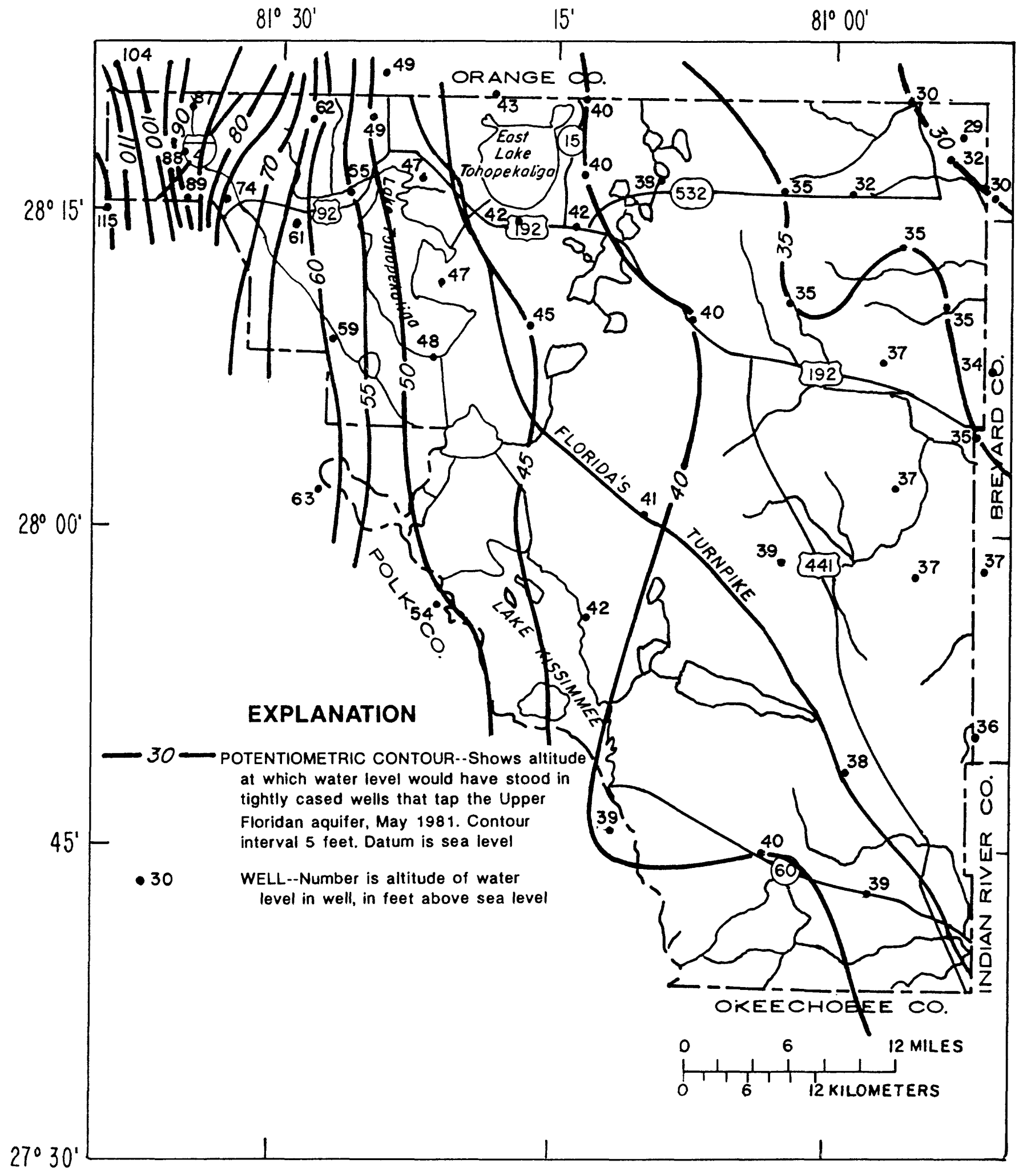

Figure 30. Potentiometric surface of the Upper Floridan aquifer, May 1981. 


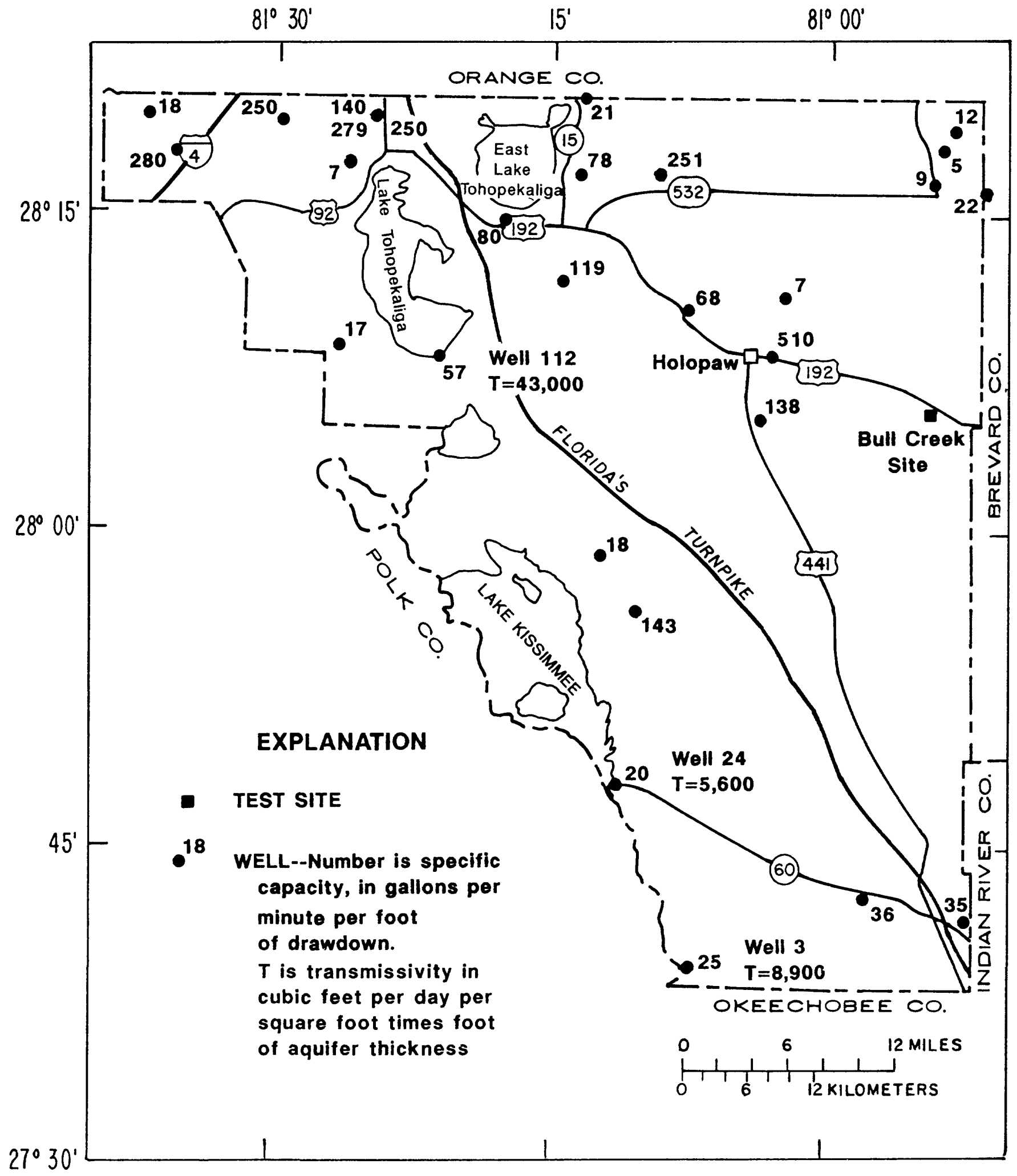

Figure 29. Specific capacity of wells completed in the Floridan aquifer system and location of aquifer test sites. 
Table 3. Specific-capacity test data for selected wells that tap the Floridan aquifer system [Source of data: C, consultant report; D, driller's report; SF, South Florida Water Management District; U, U.S. Geological Survey. gal/min, gallon per minute; (gal/min)/ft, gallon per minute per foot; --, no data]

\begin{tabular}{|c|c|c|c|c|c|c|c|}
\hline \multirow{2}{*}{$\begin{array}{c}\text { Well } \\
\text { no. }\end{array}$} & \multirow{2}{*}{$\begin{array}{c}\text { Well } \\
\text { identification } \\
\text { no. }\end{array}$} & \multirow{2}{*}{$\begin{array}{c}\text { Depth of } \\
\text { well (feet } \\
\text { below land } \\
\text { surface) }\end{array}$} & \multicolumn{2}{|c|}{ Casing } & \multirow{2}{*}{$\begin{array}{l}\text { Pumping } \\
\text { rate } \\
\text { (gal } / \mathrm{min} \text { ) }\end{array}$} & \multirow{2}{*}{$\begin{array}{c}\text { Specific } \\
\text { capacity } \\
{[(\mathrm{gal} / \mathrm{min}) / \mathrm{ft}]}\end{array}$} & \multirow{2}{*}{$\begin{array}{c}\text { Source } \\
\text { of } \\
\text { data }\end{array}$} \\
\hline & & & $\begin{array}{l}\text { Depth } \\
\text { (feet) }\end{array}$ & $\begin{array}{c}\text { Diameter } \\
\text { (inches) }\end{array}$ & & & \\
\hline 3 & 273929081080601 & 1,000 & 260 & 6 & 446 & 25 & $\mathrm{SF}, \mathrm{U}$ \\
\hline 7 & 274152080530101 & 680 & 326 & 8 & 350 & 35 & $\mathrm{U}$ \\
\hline 16 & 274307080582401 & 767 & 218 & 6 & 110 & 36 & $\mathrm{SF}, \mathrm{U}$ \\
\hline 24 & 274806081115501 & 880 & 172 & 6 & 475 & 20 & SF \\
\hline 52 & 275634081102701 & 869 & 249 & 10 & 1,000 & 143 & $\mathrm{D}$ \\
\hline 59 & 275901081121501 & 600 & 258 & 10 & 374 & 18 & $\mathrm{U}$ \\
\hline 85 & 280533081041001 & 891 & 354 & 13 & 1,650 & 138 & D \\
\hline 112 & 280823081210301 & 980 & 160 & 6 & 838 & 57 & SF \\
\hline 113 & 280826081031801 & 1,097 & 322 & 10 & 970 & 510 & $\mathrm{C}$ \\
\hline 118 & 280905081270101 & 398 & 134 & 6 & 300 & 17 & $\mathrm{SF}, \mathrm{U}$ \\
\hline 127 & 281037081075101 & 457 & 282 & 8 & 270 & 68 & U \\
\hline 130 & 281116081024101 & 513 & 210 & 12 & 305 & 7 & $\mathrm{U}$ \\
\hline 135 & 281159081142801 & 622 & 320 & -- & 430 & 119 & $\mathrm{SF}, \mathrm{U}$ \\
\hline 150 & 281456081171701 & 614 & 481 & 8 & 260 & 80 & SF,U \\
\hline 163 & 281630080544203 & 445 & 201 & 9 & 150 & 9 & $\mathrm{U}$ \\
\hline 166 & 281632080515001 & 253 & -- & 6 & 430 & 22 & $\mathrm{U}$ \\
\hline 169 & 281714081093001 & 740 & 389 & 8 & 276 & 251 & $\mathrm{U}$ \\
\hline 170 & 281719081134001 & 474 & 239 & 8 & 326 & 78 & SF,U \\
\hline 177 & 281726081262301 & 175 & 140 & 6 & 50 & 7 & U \\
\hline 179 & 281802081351601 & 450 & 85 & 10 & 310 & 280 & $\mathrm{SF}, \mathrm{U}$ \\
\hline 182 & 281820080540501 & 603 & 108 & 6 & 46 & 5 & $\mathrm{U}$ \\
\hline 183 & 281919080533301 & 344 & 163 & 4 & 136 & 12 & $\mathrm{U}$ \\
\hline 184 & 281922081244301 & 375 & 236 & 8 & 500 & 250 & $\mathrm{U}$ \\
\hline 186 & 281937081245901 & 1,195 & 283 & 16 & 2,513 & 140 & D \\
\hline 187 & 281937081250101 & 458 & 278 & 16 & 2,513 & 279 & $\mathrm{D}$ \\
\hline 190 & 281955081370701 & 300 & 99 & 6 & 240 & 18 & $\mathrm{U}$ \\
\hline 195 & 282051081133201 & 470 & 373 & 6 & 320 & 21 & D \\
\hline
\end{tabular}

\section{Description of Wells that Tap the Floridan Aquifer System}

The records for about 200 wells in the Floridan aquifer system used for data analysis in this report are stored in the computer files of the U.S. Geological Survey and are shown in appendix I. The records represent only a small percentage of the number stored in the computer files, and even a smaller percentage of the wells that have been drilled in the study area. However, some general observations about wells tapping the Floridan aquifer system can be made from available records and from field observations.

Except for northwestern Osceola County, depths of wells in the Floridan aquifer system generally are a function of a combination of factors, including desired well yield, constraints of drilling costs, and potential degradation of water quality with increased depth. The water quality (as dictated by the proposed use of water) and the productivity of a well are the chief considerations for any well installation. Therefore, wells generally are drilled to depths that meet or most closely approximate required yields and water-quality needs within economic limits. Relatively shallow wells are located where the top of the Floridan aquifer system is at a shallow depth and where chloride concentrations increase rapidly with depth of penetration. Relatively deep wells are located where high yields are required, where the aquifer system is deeply buried, and where chloride concentrations are within acceptable limits at a considerable depth. Inventoried water wells range in depth from 150 to $1,470 \mathrm{ft}$. Most wells in the county are used for irrigation and generally are capable of yielding several hundred gallons of water per minute. Large-diameter, public-supply wells and irrigation wells are known to yield several thousand gallons of water per minute.

Wells completed in the Floridan aquifer system that yield excessively saline water usually are plugged or abandoned. However, in places where a modest amount of acceptable water can be obtained from the upper part of the well, it may be feasible to plug the bottom section of the well, sealing off the lower contributing saline zone or zones, rather than abandoning the well. 


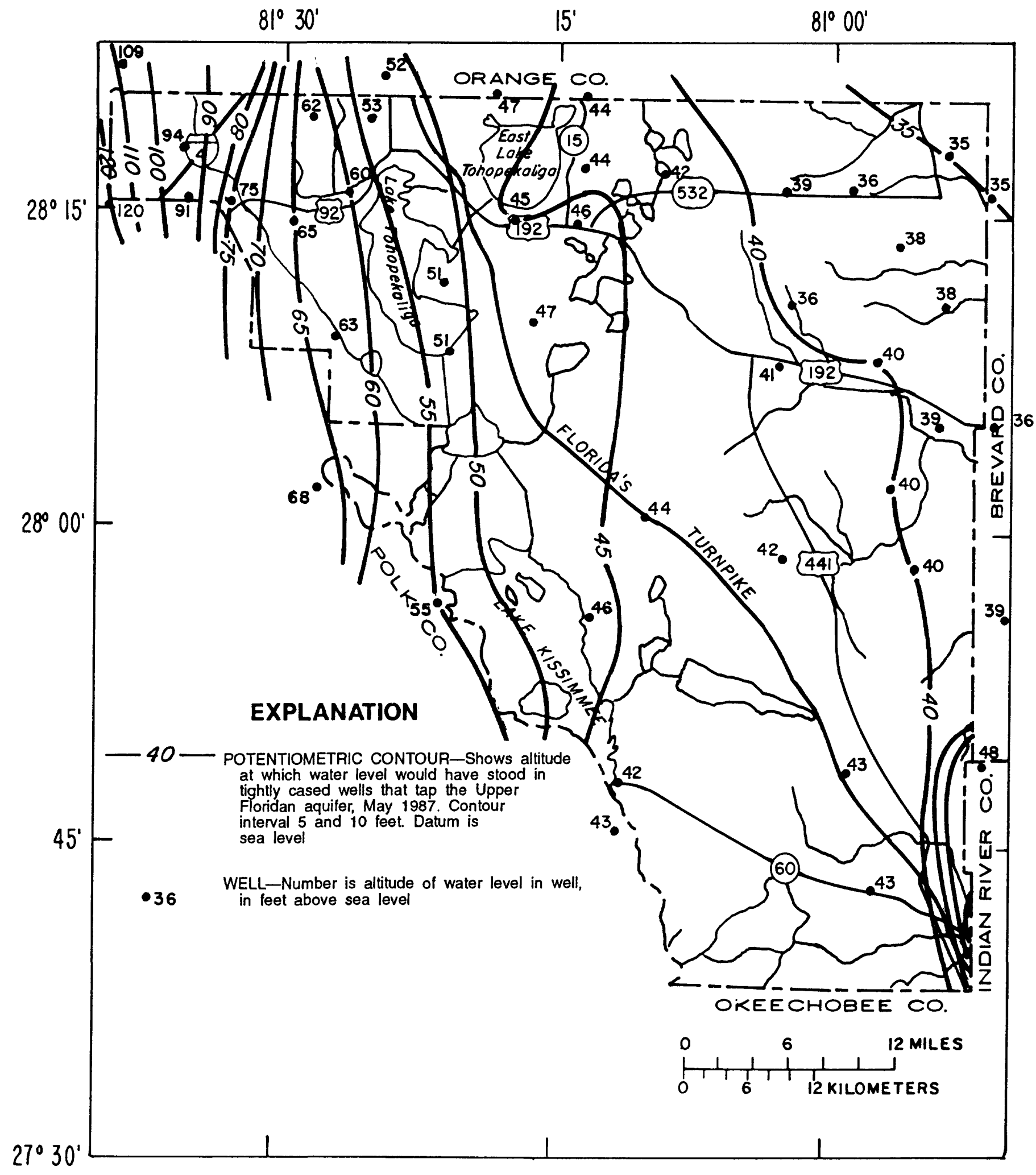

Figure 31. Potentiometric surface of the Upper Floridan aquifer, May 1987. 


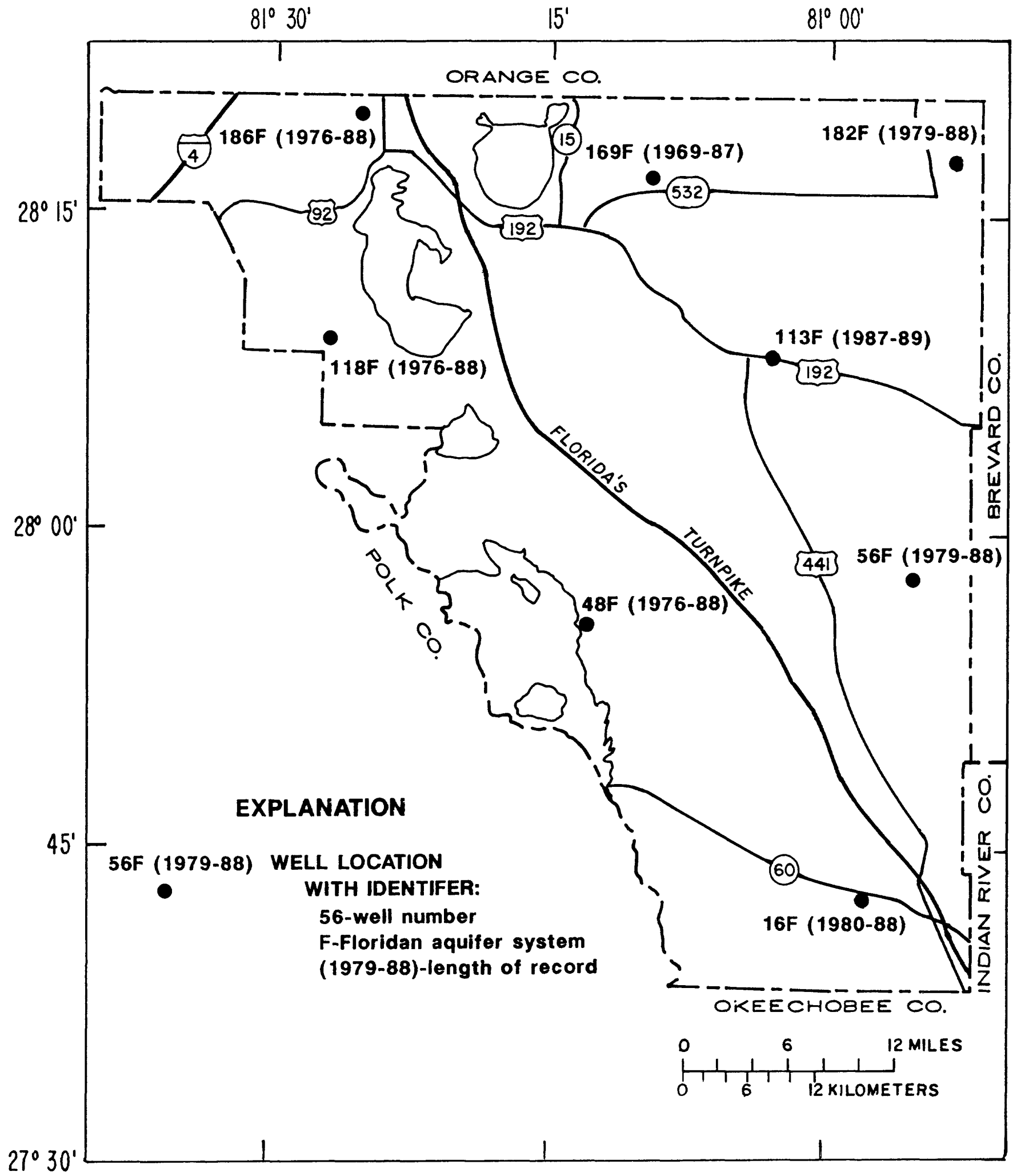

Figure 32. Location of wells in the Floridan aquifer system for which hydrographs are shown. 


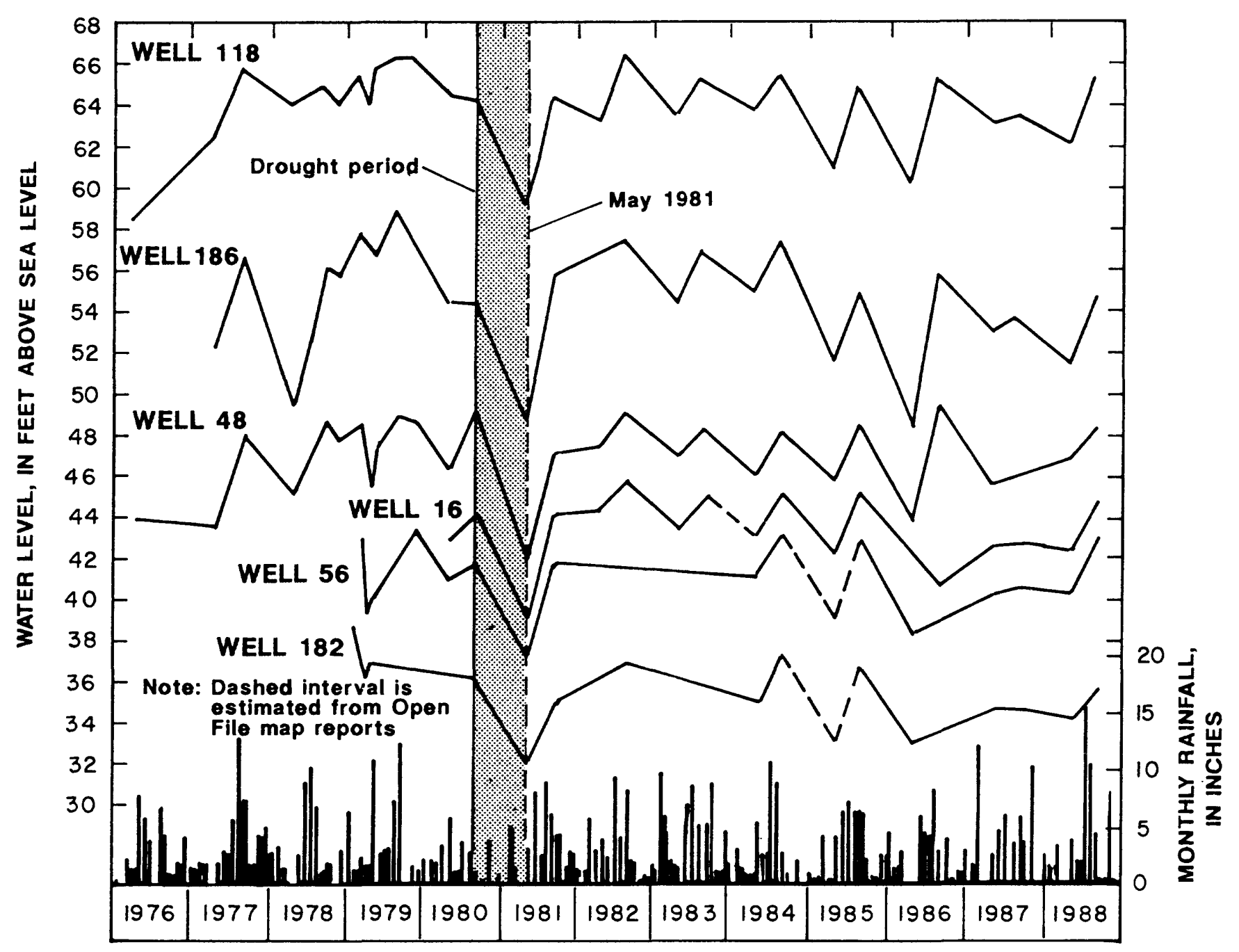

Figure 33. Water levels in six wells that monitor the potentiometric surface of the Upper Floridan aquifer, and monthly rainfall at Kissimmee, 1976-88.

parts of 1980 and 1981, and probably the effects of regional pumping, resulted in a record low May 1981 water-level altitude $(38.90 \mathrm{ft}$ ) in well 169. Low May water levels in well 169 typically have altitudes of 40 to $41 \mathrm{ft}$ (fig. 22).

Long-term trends of water levels in wells tapping the Floridan aquifer system in Osceola County are due to prolonged change in recharge and to water-use activities such as irrigation and public-supply pumpage. Long-term trends due to pumpage are difficult to ascertain because they may be masked by the effects of variations in recharge. Most development in the county has occurred in the last decade (1977-87), so long-term water-level trends due to pumpage have not been established.

Bush and Johnston (1988, pl. 6) reported that on a regional basis the net head decline in the Upper Floridan aquifer in Osceola County was less than $15 \mathrm{ft}$ from predevelopment (1930's) to 1980. Franks (1982, fig. 6) reported a decline of less than $10 \mathrm{ft}$ in most of the county during the period 1961-80, with a decline of 10 to $20 \mathrm{ft}$ in a relatively small area that extends approximately from Orlando to Kissimmee and St. Cloud. Comparison of the predevelopment potentiometric-surface map (Bush and Johnston, 1988, pl. 4) with the May 1987 potentiometricsurface map shows that heads in most of the county have declined 7 to $15 \mathrm{ft}$ (fig. 36). Heads in a narrow strip in northwestern Osceola County have declined 15 to $20 \mathrm{ft}$. In the Kissimmee and St. Cloud well-field areas, water level declines are about $2 \mathrm{ft}$ greater than the general decline in the county. Heads declined less than $7 \mathrm{ft}$ in two small areas in extreme northwestern and west-central Osceola County.

The hydrograph of well 169 (fig. 22) indicates no significant upward or downward trend of water levels in the Upper Floridan aquifer in the period 1973 to 1980 . Subsequent to the drought conditions in 1980-81 that caused a record low water level of $38.90 \mathrm{ft}$, the water level in well 169 rose to a record high of $46.80 \mathrm{ft}$ in 1983 . The hydrograph indicates a 


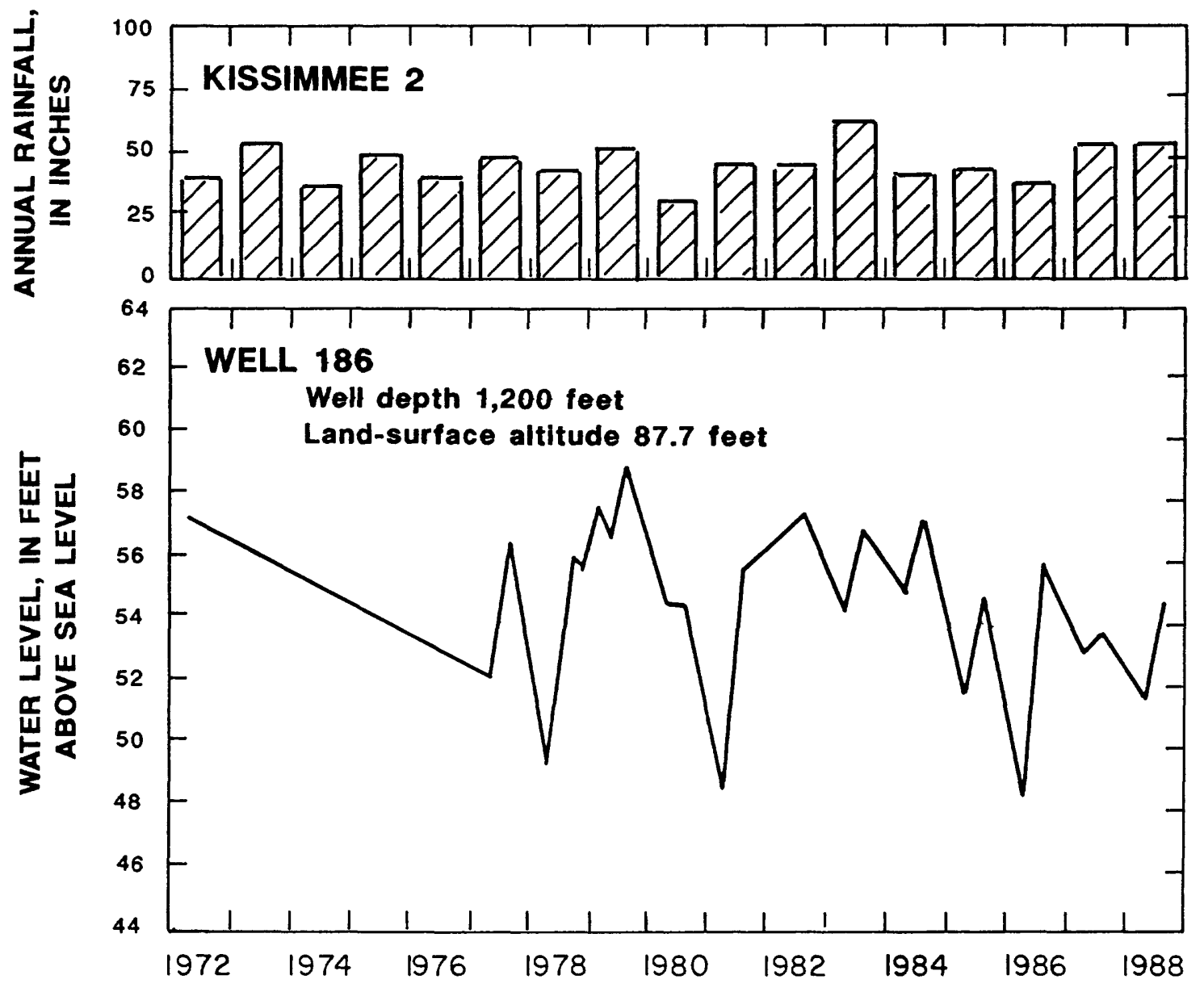

Figure 34. Water level in well 186 in an area affected by pumping, and annual rainfall at Kissimmee, 1972-88.

slight downward trend since 1983 . The hydrograph of well 186 (fig. 34), a public-supply well in Kissimmee, also indicates a slight downward trend since 1984. Belowaverage rainfall during the 1978-88 decade (based on the long-term average for $1930-88$, fig. 5) may be partially responsible for these trends. Hydrographs of wells used to prepare the potentiometric-surface maps (fig. 33) show no upward or downward trend of water levels in the Upper Floridan aquifer during the period 1979 through 1988.

In the future, water levels in the Floridan aquifer system may decline in the Kissimmee-St. Cloud area of northwestern Osceola because of an anticipated increase of public-supply water use by rapidly expanding commercial, industrial, and residential development. However, the potential decline may be mostly offset by reduced irrigation pumpage where urban development has replaced groveland. If the amount of water used for public supply is less than the amount previously used for irrigation, water levels may rise unless additional demands are placed on the aquifer.

\section{Recharge and Discharge}

In the recharge areas of Osceola County (fig. 11), most recharge to the Floridan aquifer system is from downward leakage from the surficial aquifer system, through the intermediate confining unit, and into the Upper Floridan aquifer, although some recharge is by lateral inflow from adjacent areas. The rate of vertical leakage is proportional to the head difference between the surficial aquifer system and the Upper Floridan aquifer, and the hydraulic conductivity of the intermediate confining unit, but inversely proportional to the thickness of the confining unit. Tibbals (1990, fig. 22) reported that in most of the recharge area of Osceola County (fig. 11), the model-derived leakage rate (recharge) is approximately $1 \mathrm{in} / \mathrm{yr}$.

Discharge from the Floridan aquifer system in Osceola County occurs by diffuse upward leakage in discharge areas (fig. 11) where the potentiometric surface is above the water table. Some discharge also occurs by pumping, by flowing 
wells, and by lateral outflow through the county boundary. Tibbals (1990, fig. 22) indicated that in the discharge areas of the Upper Floridan aquifer, model-derived leakage is about $0.5 \mathrm{in} / \mathrm{yr}$ in most of the area along the eastern county boundary and ranges from about 2 to 6 in. along the western county boundary.

\section{Water Quality}

A significant amount of water that recharges the Floridan aquifer system in Osceola County (fig. 11) originates as rainfall on the Lake Wales Ridge and adjacent areas of northwestern Osceola County and eastern Polk County (Frazee, 1980; and Phelps, 1984). The mineralization of ground water increases as it moves eastward beneath the county toward the Atlantic coastline. The salinity of water in the Floridan aquifer system is also affected by ancient seawater trapped in the sediments during an earlier geologic time (Sprinkle, 1982).

In most of the county, water in the Upper Floridan aquifer is fresh (less than $500 \mathrm{mg} / \mathrm{L}$ dissolved solids), although saline water is present at depth beneath the entire county. Salinity increase with depth is minimal in the Upper Floridan aquifer, erratic in the middle semiconfining unit, and probably rapid in the Lower Floridan aquifer. Miller (1986, p. B63) reported that water movement is generally sluggish in the Lower Floridan aquifer, and therefore, little flushing of ancient seawater has occurred and the water remains saline.

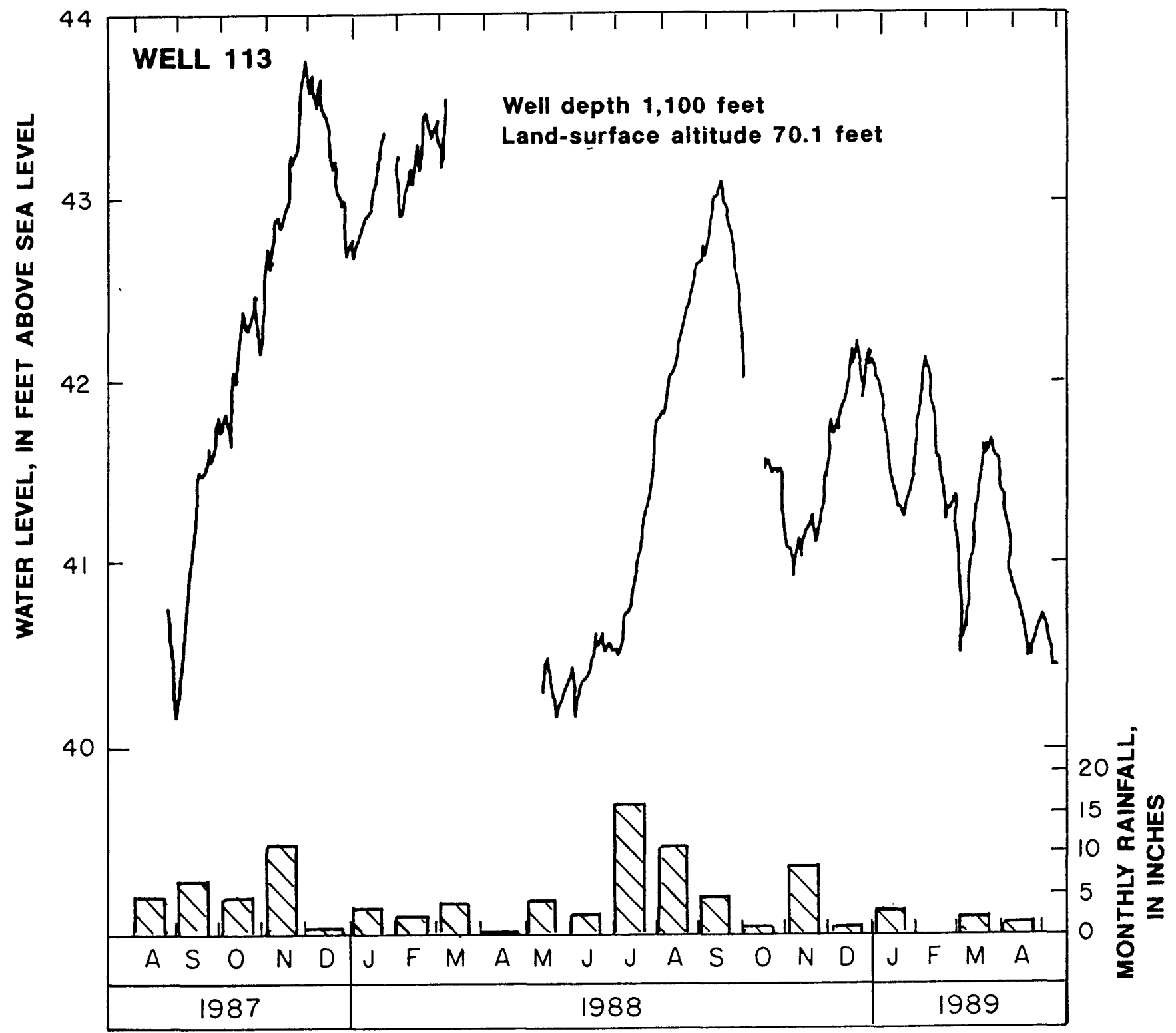

Figure 35. Daily water level in well 113, and monthly rainfall at Kissimmee, 1987-89. 


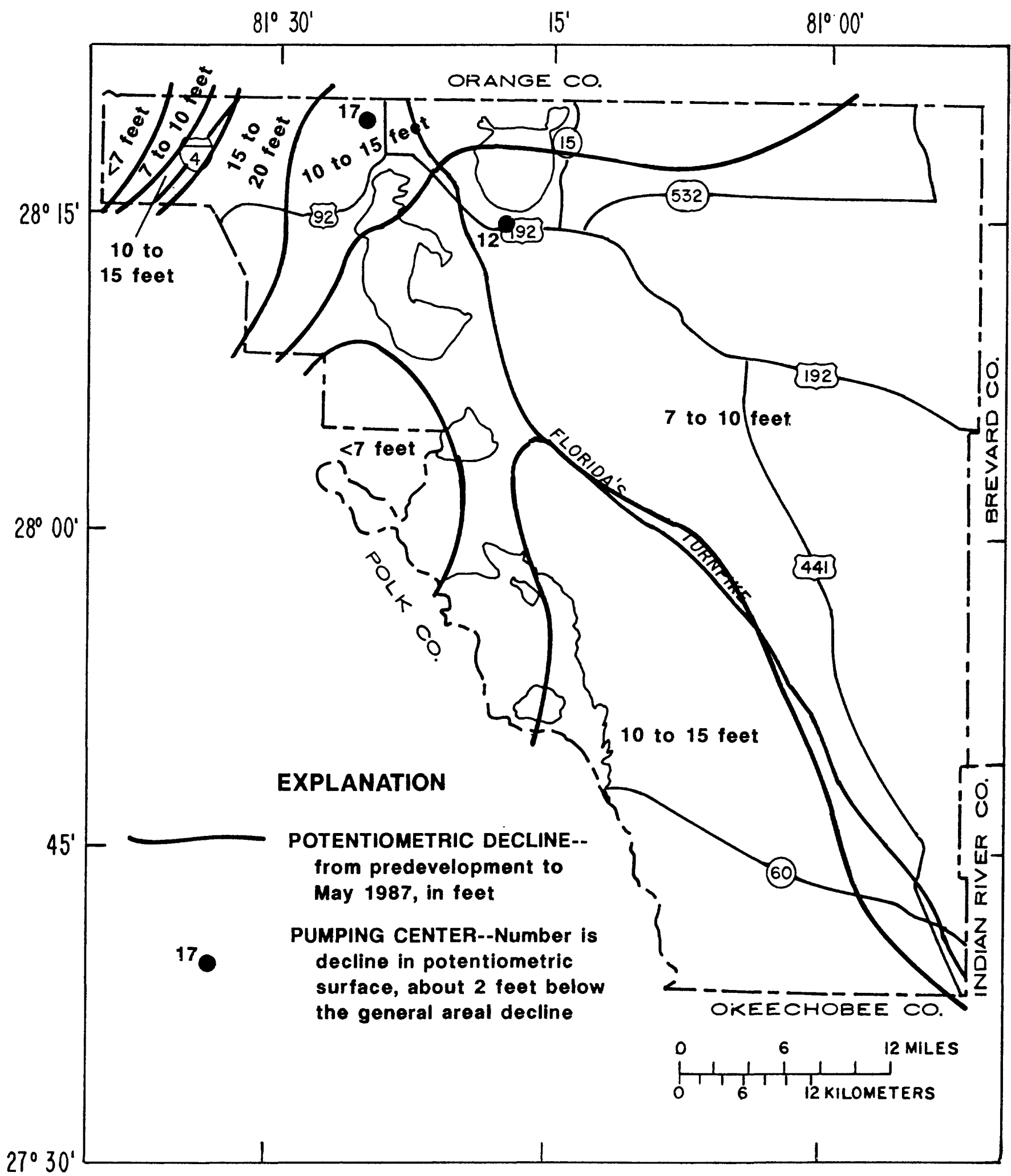

Figure 36. Decline in the potentiometric surface of the Upper Floridan aquifer from predevelopment conditions to May 1987. 
SPECIFIC CONDUCTANCE,

IN MICROSIEMENS

PER CENTIMETER AT

25 DEGREES CELSIUS

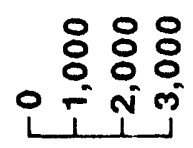

SCALE OF DIAMETERS

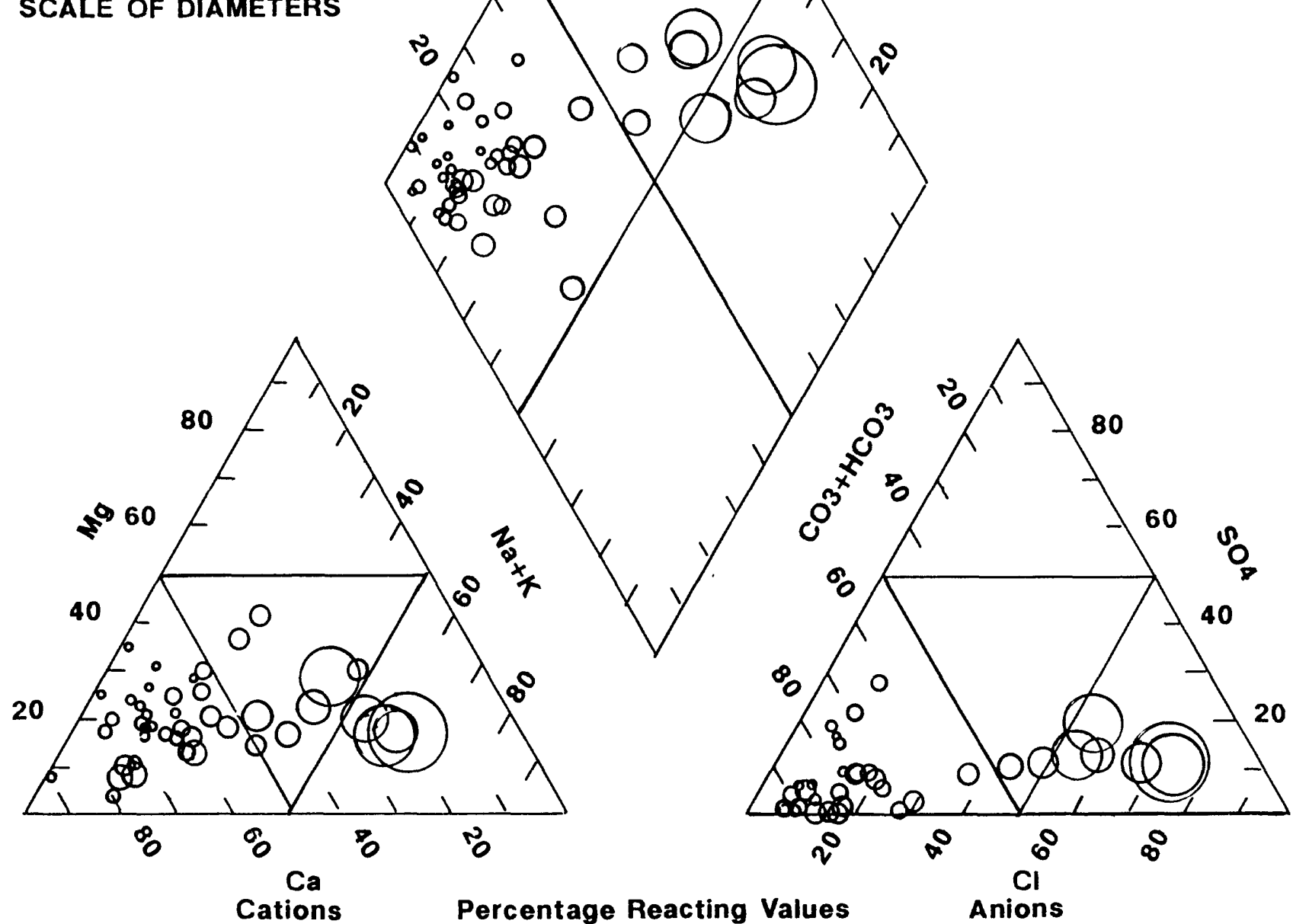

Figure 37. Major dissolved-constituent ratios in water from wells completed in the Floridan aquifer system.

The quality of water from a well completed in the Floridan aquifer system is a composite of the quality of water in the various producing zones penetrated by the open borehole. Water-quality data indicate that water from the Upper Floridan aquifer in most of the county is hard $(121-180 \mathrm{mg} / \mathrm{L}$ as $\mathrm{CaCO}_{3}$ ), has a relatively high dissolved-solids concentration $(250-500 \mathrm{mg} / \mathrm{L})$, and has a $\mathrm{pH}$ greater than 7 . In northwestern Osceola County, dissolved-solids concentrations generally are less than $250 \mathrm{mg} / \mathrm{L}$. In a relatively narrow band of northeastern Osceola County (where chloride concentrations exceed $250 \mathrm{mg} / \mathrm{L}$ ) water is a sodium chloride type. In the remainder of the county, the water is a calcium magnesium bicarbonate type (fig. 37). Sodium chloride type water is generally more mineralized (contains a higher concentration of dissolved solids) than calcium bicarbonate water.

Major constituent concentrations in water from the Floridan aquifer system vary areally and with depth. Dissolved-solids concentrations in water from 102 wells ranged from $89 \mathrm{mg} / \mathrm{L}$ to $896 \mathrm{mg} / \mathrm{L}$ (table 4 and fig. 38). Chloride concentration varies over a wider range than the other major dissolved constituent concentrations, ranging from less than $0.1 \mathrm{mg} / \mathrm{L}$ to more than $2,000 \mathrm{mg} / \mathrm{L}$. 
Table 4. Summary of selected properties, major constituent concentrations, nitrogen species concentrations, and phosphorus concentrations in water from wells completed in the Floridan aquifer system

[Concentrations are for dissolved material in milligrams per liter unless otherwise noted. Specific conductance is in microsiemens per centimeter at 25 degrees Celsius. Water temperature is in degrees Celsius. $\mathrm{pH}$ is in standard units. Iron is in micrograms per liter. P10 and P90 are the values that are exceeded in 10 and 90 percent of the samples, respectively. The latest sample is used for wells that have been sampled more than once. $<$, less than]

\begin{tabular}{lcccccc}
\hline \multicolumn{1}{c}{$\begin{array}{c}\text { Property or } \\
\text { constituent }\end{array}$} & $\begin{array}{c}\text { No. of } \\
\text { samples }\end{array}$ & Minimum & P10 & Median & P90 & Maximum \\
\hline Specific conductance & 102 & 150 & 200 & 480 & 1,420 & 7,250 \\
Dissolved solids (500) & 102 & 89 & 118 & 300 & 692 & 896 \\
Water temperature & 62 & 22.0 & 23.5 & 24.0 & 25.5 & 27.5 \\
pH (6.5-8.5) & 68 & 6.6 & 7.3 & 7.7 & 8.2 & 8.4 \\
Calcium & 74 & 13 & 25 & 48 & 77 & 130 \\
Magnesium & 74 & 2.1 & 4.3 & 7.4 & 26 & 37 \\
Sodium & 74 & $<3.0$ & $<3.0$ & 9.5 & 85 & 254 \\
Potassium & 74 & $<.5$ & .5 & 1.0 & 3.2 & 62 \\
Alkalinity & 68 & 78 & 92 & 150 & 250 & 370 \\
Chloride (250) & 106 & $<.1$ & 6.0 & 25 & 300 & 2,100 \\
Sulfate & 88 & $<.5$ & .8 & 12 & 69 & 130 \\
Iron (300) & 46 & $<10$ & $<10$ & 70 & 470 & 2,100 \\
& & & & & & \\
Organic nitrogen & 34 & $<.1$ & $<.1$ & .3 & .82 & 1.61 \\
Ammonia nitrogen & 33 & $<.01$ & .02 & .17 & .50 & 1.20 \\
Nitrite nitrogen & 39 & $<.01$ & $<.01$ & $<.01$ & $<.01$ & .04 \\
Nitrate nitrogen (10) & 41 & $<.01$ & $<.01$ & $<.01$ & .18 & 1.10 \\
Total phosphorus, as P & 32 & $<.01$ & $<.01$ & $<.04$ & .09 & .40 \\
& & & & & & \\
\hline
\end{tabular}

\footnotetext{
${ }^{1}$ Numbers in parentheses under property or constituent are secondary standards for drinking water established by the Florida Department of Environmental Regulation (1989).
}

Water from most of the 46 sampled wells meets secondary drinking-water standards established by the Florida Department of Environmental Regulation (1990). Dissolvedsolids and chloride concentrations exceeded standards (500 $\mathrm{mg} / \mathrm{L}$ and $250 \mathrm{mg} / \mathrm{L}$, respectively) in less than 25 percent of the wells sampled (fig. 38). Sulfate concentrations did not exceed the standard of $250 \mathrm{mg} / \mathrm{L}$ in any of the samples analyzed. Iron concentrations (table 4) exceeded the standard of $300 \mu \mathrm{g} / \mathrm{L}$ in water from less than half of the 46 wells that were sampled. The $\mathrm{pH}$ of water from the Floridan aquifer system was within the acceptable range (6.5-8.5) in all wells.

Except for nitrate, there are no drinking water standards for nitrogen and phosphorus species. The presence of high concentrations of nitrogen and phosphorus in ground water could be an indication of contamination of recharge from fertilizers, sewage, or other sources. Nitrogen and phosphorus concentrations were determined in water from 41 and 32 Floridan aquifer system wells, respectively (table 4). The nitrate concentration (as $\mathrm{N}$ ) in water from all wells was much less than the drinking-water standard of $10 \mathrm{mg} / \mathrm{L}$. Organic and ammonia nitrogen concentrations accounted for most of the total nitrogen. Except for organic nitrogen, concentrations of nitrogen and phosphorus in ground-water samples from Osceola County were similar in magnitude to those found in
Orange County during a survey of public-supply wells, as given below for a comparison of total concentrations (not filtered) between the two areas. Data for the Orange County supply wells were reported by Schiner and German (1983).

[Median concentrations, in milligrams per liter]

\begin{tabular}{lrrrrr}
\hline & $\begin{array}{c}\text { Organic } \\
\text { nitrogen }\end{array}$ & $\begin{array}{c}\text { Ammonia } \\
\text { nitrogen }\end{array}$ & $\begin{array}{c}\text { Nitrite } \\
\text { nitrogen }\end{array}$ & $\begin{array}{c}\text { Nitrate } \\
\text { nitrogen }\end{array}$ & $\begin{array}{c}\text { Total } \\
\text { phosphorus }\end{array}$ \\
\cline { 2 - 7 } Orange County & 0.02 & 0.25 & $<0.01$ & $<0.01$ & 0.07 \\
Osceola County & .30 & .17 & $<.01$ & $<.01$ & .04 \\
\hline
\end{tabular}

The reason for the higher organic nitrogen in Osceola County is not known, but could be an indication of relatively high concentrations of organic nitrogen in recharge to the Floridan aquifer system from the surficial aquifer. The low concentration of nitrate might indicate that the source of the nitrate is not fertilizers.

Undesirably high concentrations of chemical constituents could be introduced into the aquifer from recharge areas within and outside the county (fig. 11). In the discharge areas of the county, the high potentiometric surface of the Upper Floridan aquifer relative to the water table prevents constituents on the land surface from moving downward into the aquifer system. 


\section{Areal Distribution of Chloride Concentration}

Chloride concentrations in water from the Floridan aquifer system may vary considerably areally, vertically, and temporally. Chloride concentration at a specific location cannot be accurately estimated, but for most sites, generalizations can be made using patterns of occurrence.

A highly generalized map that shows the distribution of chloride concentrations in water from wells that tap the Upper Floridan aquifer is shown in figure 39. Too few data are available on chloride concentrations in the Lower Floridan aquifer to prepare a similar map for the aquifer.
Chloride concentrations in water from wells that tap the Upper Floridan aquifer in Osceola County range from 4 to $1,100 \mathrm{mg} / \mathrm{L}$. The lowest concentrations are in recharge areas of the Floridan aquifer system on the Lake Wales Ridge in northwestern Osceola County. In the northeastern corner of the county, concentrations range from about $250 \mathrm{mg} / \mathrm{L}$ to at least $1,100 \mathrm{mg} / \mathrm{L}$. Chloride concentrations in the western half of the county are less than $50 \mathrm{mg} / \mathrm{L}$. Chloride concentrations range from 101 to $500 \mathrm{mg} / \mathrm{L}$ in a wide band in eastcentral Osceola. This area is surrounded by an area in which chloride concentrations range from 51 to $100 \mathrm{mg} / \mathrm{L}$. The area of $101-$ to- $500 \mathrm{mg} / \mathrm{L}$ concentrations may be present because

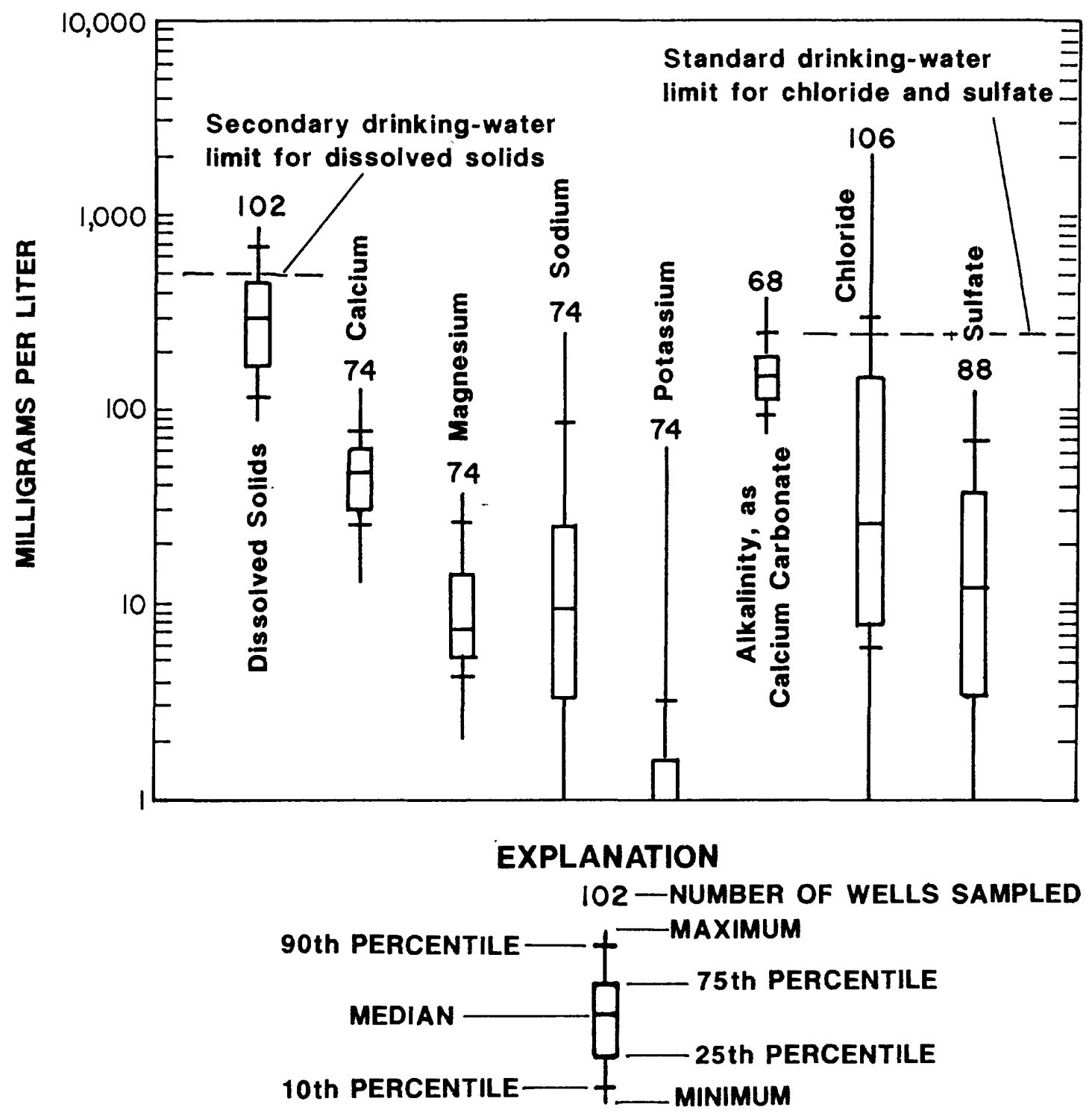

(Dissoived-sollds concentrations for some wells are estimated from specific conductance.)

Figure 38. Distribution of major constituent concentrations in water from wells completed in the Floridan aquifer system. 


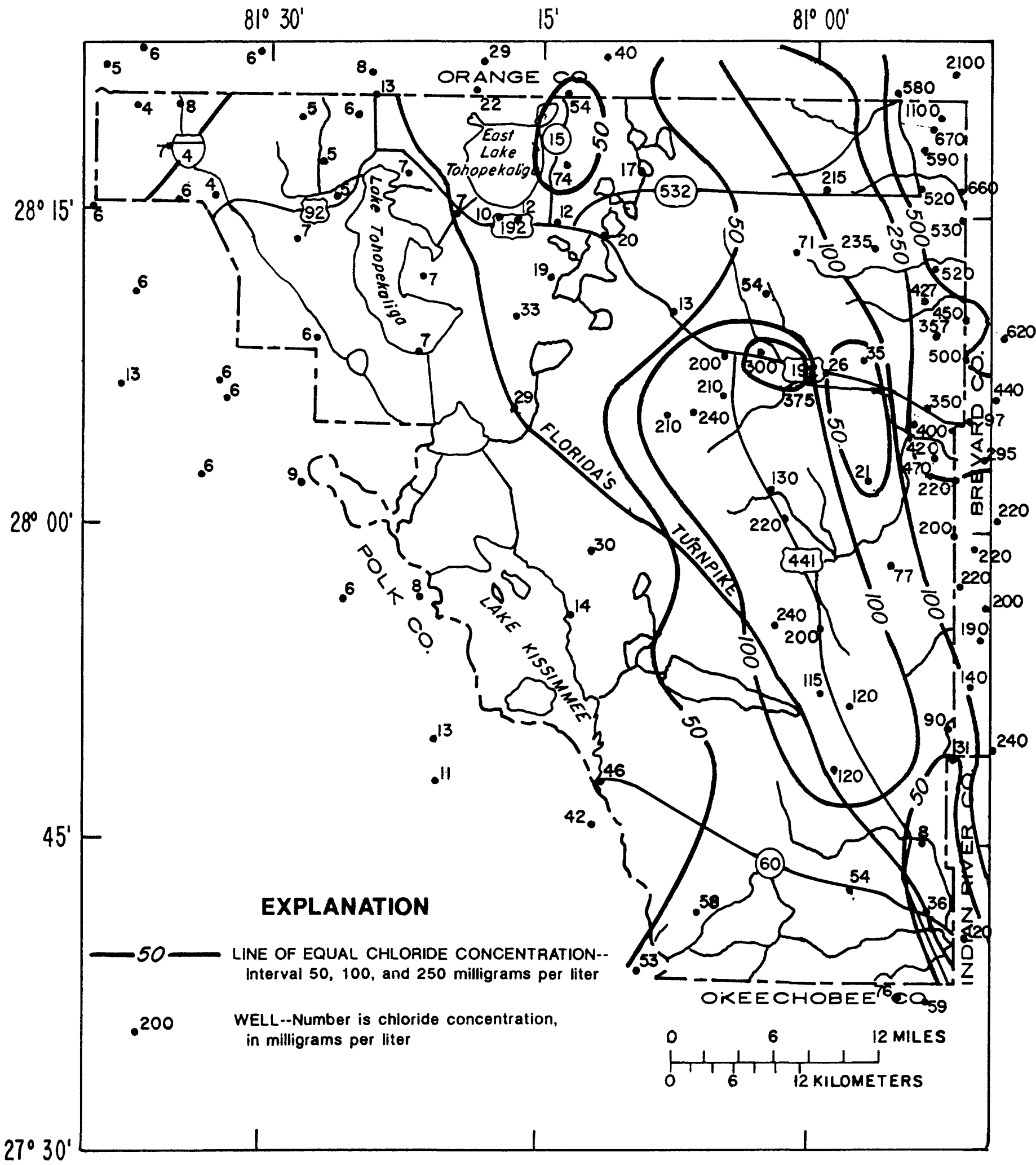

Figure 39. Chloride concentrations in water from wells that tap the Upper Floridan aquifer. 
wells there are drilled deeper than the wells in surrounding areas and probably tap higher chloride concentration water. The relatively high chloride concentrations east of East Lake Tohopekaliga (54 and $74 \mathrm{mg} / \mathrm{L}$ ) and west of Holopaw (33 $\mathrm{mg} / \mathrm{L}$ ) may have been caused by upconing at individual wells. The relatively low chloride concentration area (2-50 $\mathrm{mg} / \mathrm{L}$ ) in southeastern Osceola County is situated on an elevated section of the Talbot Terrace and may be a recharge area of the Upper Floridan aquifer. The area of low chloride concentrations east of Holopaw (2-50 mg/L) may be pockets of freshwater that were trapped in the aquifer at a low stand of the sea during the Pleistocene Epoch (Tibbals, 1990, p. E45).

\section{Variations of Chloride Concentration in Wells}

Sprinkle (1982) reported that in the Tertiary aquifer system (Floridan aquifer system), significant chemical differences may exist in the waters from proximate wells or concentrations in water from a well may vary substantially from year to year. Variations of chloride concentration in ground water may be related to head changes and changes in flow contributions of producing zones. Heavy pumping could lower the head in a freshwater well enough to cause movement of saline water into the well. Variations in the chloride concentration of water from a well sampled periodically may also be because of sampling techniques or to the geohydrologic characteristics of the well. Many high-capacity irrigation wells tap the Floridan aquifer system. In groves, these wells are periodically used during dry weather periods and additionally during freeze periods. Chloride concentrations of water from periodically discharging wells are more likely to vary than those in wells that discharge most of the time or continuously.

In most of northern Osceola County, chloride concentrations change little with well depths to as much as 1,000 ft. Post, Buckley, Schuh, and Jernigan, Inc. (1987) reported that the water quality in well 113 , near Holopaw, did not change significantly during the drilling operation. The $1,100-\mathrm{ft}$ deep well is cased to the top of the Upper Floridan aquifer at about $330 \mathrm{ft}$ below land surface and penetrates the top of the middle semiconfining unit at a depth of $642 \mathrm{ft}$. In the interval $398 \mathrm{ft}$ to $1,100 \mathrm{ft}$ below land surface, chloride concentrations ranged from 278 to $331 \mathrm{mg} / \mathrm{L}$, specific conductance ranged from 1,120 to $1,340 \mu \mathrm{S} / \mathrm{cm}$, and dissolved-solids concentrations ranged from 642 to 706 $\mathrm{mg} / \mathrm{L}$. At the end of a 5-hour yield test, the chloride concentration was $370 \mathrm{mg} / \mathrm{L}$; the specific conductance was 1,300 $\mu \mathrm{S} / \mathrm{cm}$; and the dissolved-solids concentration, $708 \mathrm{mg} / \mathrm{L}$.

At the Bull Creek site in east-central Osceola County (fig. 29), a large change in chloride concentration was reported at a depth of about $1,450 \mathrm{ft}$ below land surface. Water from well 104 had the following reported chloride concentrations (Post, Buckley, Schuh, and Jernigan, 1987):

\begin{tabular}{cc}
\hline $\begin{array}{c}\text { Depth below } \\
\text { land surface } \\
(\mathrm{ft})\end{array}$ & $\begin{array}{c}\text { Chloride } \\
\text { concentration } \\
(\mathrm{mg} / \mathrm{L})\end{array}$ \\
\hline 410 & 306 \\
565 & 376 \\
595 & 375 \\
848 & 426 \\
940 & 414 \\
1,443 & 421 \\
1,473 & 658 \\
1,483 & 1,080 \\
\hline
\end{tabular}

Chloride concentrations changed little at this location to a depth of $1,443 \mathrm{ft}$, but a large increase in concentration occurred in the $40-\mathrm{ft}$ interval from the $1,443 \mathrm{ft}$ to $1,483 \mathrm{ft}$. The well probably penetrates the top of the Lower Floridan aquifer at a depth of about $1,470 \mathrm{ft}$.

Planert and Aucott (1985, p. 28) noted that in the general vicinity of Holopaw and along U.S. 441 between Holopaw and Kenansville, most irrigation wells are drilled deeper than $600 \mathrm{ft}$ because a zone of high transmissivity occurs at that depth. However, wells deeper than $600 \mathrm{ft}$ in that area yield water with higher chloride concentrations than nearby wells that aie less than $600 \mathrm{ft}$ deep. For example, water from well 46 which is $800 \mathrm{ft}$ deep had a chloride concentration of $200 \mathrm{mg} / \mathrm{L}$. Water from wells 71 and 69 to the northeast about $6 \mathrm{mi}$ and to the northwest about $2 \mathrm{mi}$, respectively, from well 46 had chloride concentrations of 21 and $130 \mathrm{mg} / \mathrm{L}$. Wells 71 and 69 are $329 \mathrm{ft}$ deep and $520 \mathrm{ft}$ deep, respectively.

In southern Osceola County, chloride concentrations increase considerably at depths less than $1,000 \mathrm{ft}$. The chloride concentration of water from well 23 ( $400 \mathrm{ft}$ deep) was 46 $\mathrm{mg} / \mathrm{L}$, but water from nearby well 24 (880 ft deep) had a chloride concentration of $301 \mathrm{mg} / \mathrm{L}$.

Schiner and others $(1988$, p. 73$)$ suggested that in the areas of flowing wells (discharge areas) water-level differentials in shut-in wells can allow more highly mineralized water from deep producing zones to move upward and invade an upper producing zone. In recharge areas where water levels decrease with depth of penetration, water from an upper producing zone in a well may move downward and invade a lower producing zone that contains more highly mineralized water (fig. 40).

The volume and quality of water that moves into receiving zones of a shut-in well in a discharge area or an unpumped well in a recharge area is directly related to head differentials, transmissivities, water density, the water quality of the producing zones, and to time. If a shut-in well is allowed to flow naturally, the time required to evacuate the intruded zone in the Floridan may be longer than the period of time the well was shut-in or not pumped. This is because of the mixing of the water in the intruded zone and the hydraulics of flow in the zone. The time required to evacuate an intruded zone of an unpumped well that is then pumped is directly related to the pumping rate. 
Water from flowing wells that have been capped for a lengthy period of time typically has higher chloride concentrations than the concentrations prior to the time the well was capped. After the well is allowed to flow, chloride concentrations in the water tend to decrease toward the concentration that existed before the well was capped. The decline in chloride concentration probably reflects the slow release of mixedquality water from an upper-producing zone of higher quality water that had been intruded by relatively high chloride water from a lower zone while the well was capped.

According to Schiner and others $(1988$, p. 75$)$, water from many wells that flow continuously seem to reach an equilibrium in chloride concentration. Chloride concentrations in water from flowing wells showed little fluctuation, though their period of record covered several seasons of varying precipitation and pumping patterns. Water from flowing wells periodically opened after being capped and water from wells recently drilled may vary considerably in chloride concentration because equilibrium conditions have not been attained. Chloride concentrations in water from recently drilled wells often increase with time and with declining water levels. The amount of time required to attain waterquality equilibrium varies with the hydrologic environment of the individual well and its use.

\section{Trends in Chloride Concentrations}

Detection of possible time trends in chloride concentrations of water from wells in the Floridan aquifer system is essential to water-resources management, especially in northeastern

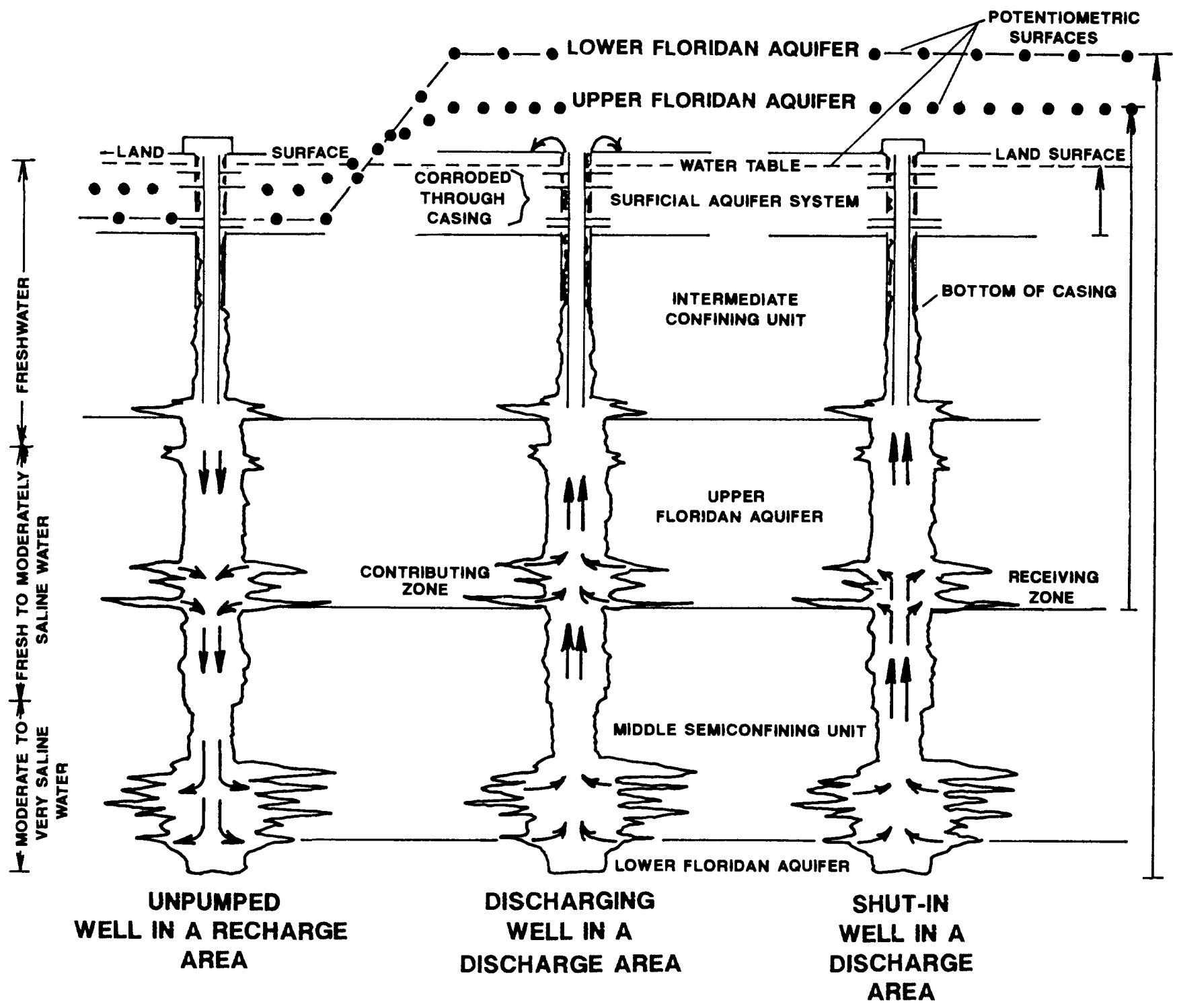

NOT TO SCALE

Figure 40. Hypothetical paths of ground-water movement in wells that penetrate the Floridan aquifer system. 


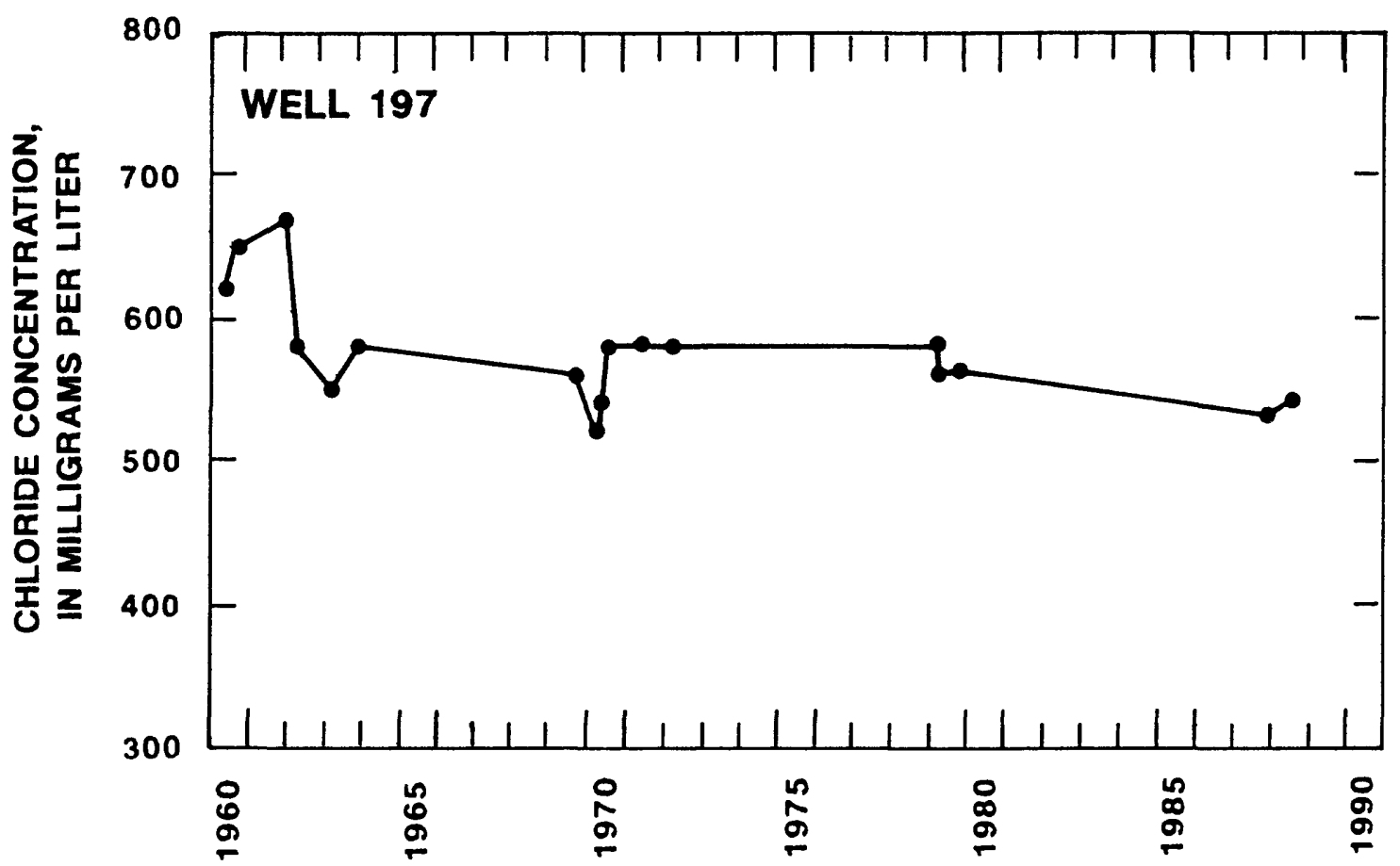

Figure 41. Chloride concentrations in water from well 197, 1960-88.

Osceola County where chloride concentrations commonly exceed $250 \mathrm{mg} / \mathrm{L}$, and in the rapidly expanding publicsupply water-use areas of Kissimmee and St. Cloud.

Thirteen wells that had chloride concentrations that exceeded $250 \mathrm{mg} / \mathrm{L}$ in 1979 were resampled in 1988 . Only well 44 had a higher chloride concentration in 1988 (400 $\mathrm{mg} / \mathrm{L})$ than in $1979(330 \mathrm{mg} / \mathrm{L})$. In the remaining 12 wells, chloride concentrations either remained about the same or declined. Water from well 36, for example, had a chloride concentration of $550 \mathrm{mg} / \mathrm{L}$ in 1979 and $330 \mathrm{mg} / \mathrm{L}$ in 1988 . The trend in chloride concentrations in water from well 197 from 1960 to 1988 (fig. 41) is probably indicative of trends in most wells in northeastern Osceola County. This well exhibited a possible slight decrease in chloride concentration but no substantial long-term trend. Chloride concentrations of eight samples of water from the Kissimmee public-supply well 186, collected aperiodically from 1978 to 1988 , ranged from less than 4 to $7.3 \mathrm{mg} / \mathrm{L}$, and showed no apparent trend.

Analysis of long-term water-quality data indicate that on a countywide basis, the chloride concentrations of water from wells in the Floridan aquifer system have not changed significantly in the 10-year period from 1978 to 1988 , and probably not since 1960 . Frazee (1980) reported that records since 1960 (covering the period to about 1973) indicate that chloride concentrations in Osceola County had remained fairly constant. Planert and Aucott (1985) reported that the distribution of chloride concentrations in water from the Floridan aquifer system had not changed appreciably in 20 years in adjacent Brevard County. Schiner and others (1988) reported that in adjacent Indian River County, countywide chloride concentrations in water from the Floridan aquifer system had not changed significantly in the 15 -year period from 1968 to 1983 . Some individual wells in Osceola County have shown increases in chloride concentration, but the increases probably reflect a local condition rather than a general trend.

\section{Availability of Water}

The Floridan aquifer system commonly yields abundant supplies of water to wells in Osceola County. About 90 percent of all ground water used in the county is from the Floridan. According to Bush and Johnston (1988, p. C70), large quantities of fresh ground water are available for future development from the Floridan aquifer system in an area that includes much of the Upper Kissimmee basin of Osceola County. Figure 42 is a modification of a map by Bush and Johnston (1988, pl. 17) that shows potentially favorable areas for future development of large ground-water supplies from the Upper Floridan aquifer, as well as less favorable areas. The map is based on chloride concentrations, dissolvedsolids concentrations, and reported transmissivity values. Large withdrawals from an area with relatively high chloride concentrations, but less than $250 \mathrm{mg} / \mathrm{L}$, under unstressed conditions, most probably would either draw water from adjacent areas of higher chloride concentration or cause upconing of high chloride-concentration water. Planert and Aucott $(1985$, p. 67) reported that based on a computer model, a well field west of Holopaw might be capable of producing $30 \mathrm{Mgal} / \mathrm{d}$ or more. The eastern border of the highly favorable area for future ground-water development shown in figure 42 is about 4 mi northwest of Holopaw. 


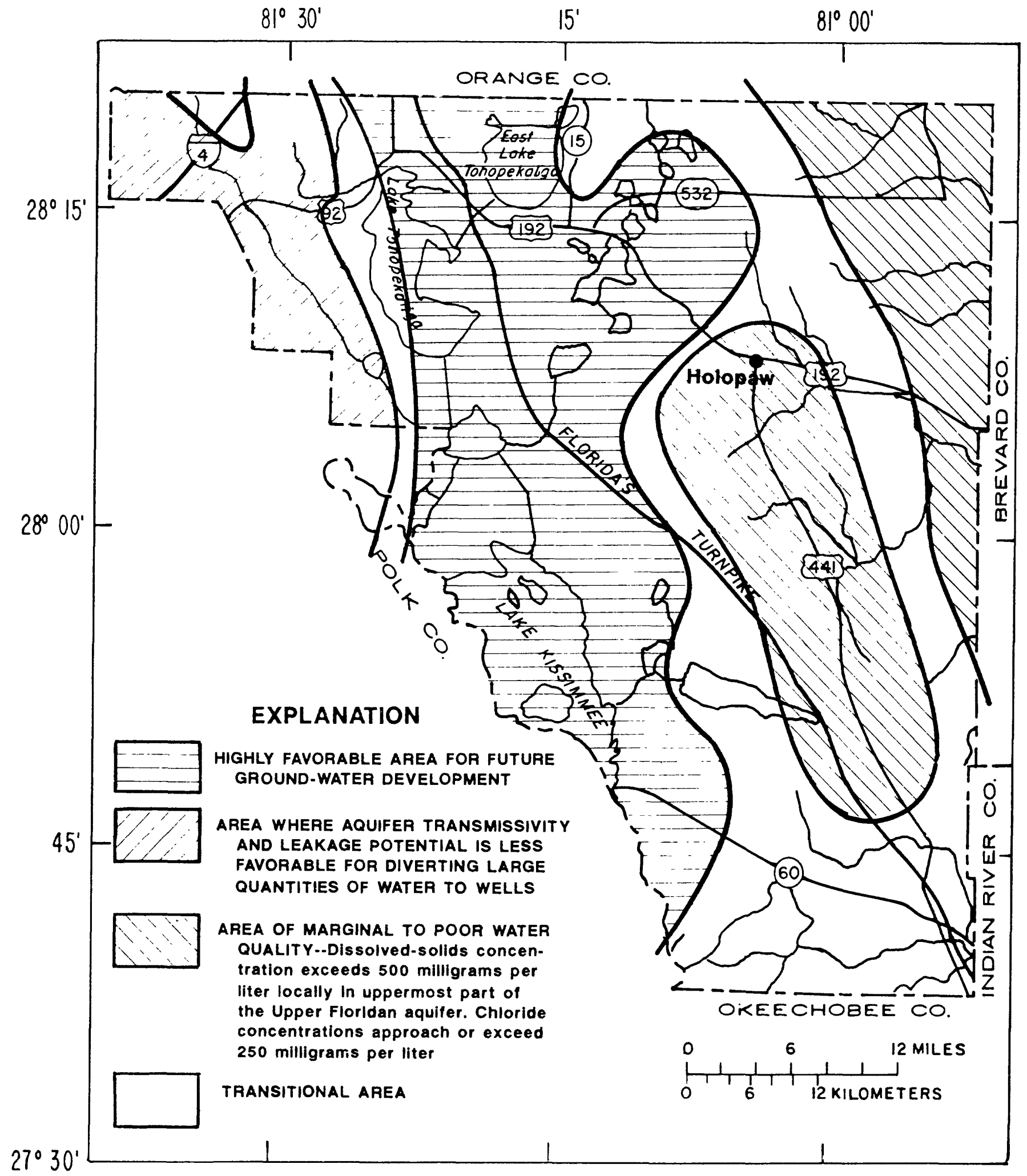

Figure 42. Favorable areas for future development of large water supplies from the Upper Floridan aquifer (modified from Bush and Johnston, 1988). 
Table 5. Average daily water use in Osceola County

[Sources of data: Pride (1973); Leach (1978; 1983); Marella (1988; 1990)]

[Source of water: SW, surface water; GW, ground water; water use in million gallons per day; --, data not collected or available; 0.0 , not used]

\begin{tabular}{|c|c|c|c|c|c|c|c|c|c|c|c|c|c|c|c|}
\hline \multirow[b]{2}{*}{ Category } & \multicolumn{3}{|c|}{1970} & \multicolumn{3}{|c|}{1975} & \multicolumn{3}{|c|}{1980} & \multicolumn{3}{|c|}{1985} & \multicolumn{3}{|c|}{1987} \\
\hline & $\overline{\mathrm{SW}}$ & $\mathrm{GW}$ & Total & $\overline{\text { SW }}$ & GW & Total & $\overline{\text { SW }}$ & $\mathrm{GW}$ & Total & $\overline{\text { SW }}$ & $\mathrm{GW}$ & Total & $\overline{\text { SW }}$ & GW & Total \\
\hline \multicolumn{16}{|l|}{ Domestic } \\
\hline Public supply & 0.0 & 2.7 & 2.7 & 0.0 & 3.7 & 3.7 & 0.0 & 4.2 & 4.2 & 0.0 & 5.7 & 5.7 & -- & 7.5 & 7.5 \\
\hline Self-supply & .0 & 1.5 & 1.5 & .0 & 1.8 & 1.8 & .0 & 3.7 & 3.7 & .0 & 4.8 & 4.8 & -. & 4.6 & 4.6 \\
\hline Total & .0 & 4.2 & 4.2 & .0 & 5.5 & 5.5 & .0 & 7.9 & 7.9 & .0 & 10.5 & 10.5 & .. & 12.1 & $12 . .1$ \\
\hline $\begin{array}{l}\text { Commercial-industrial, } \\
\text { self-supplied }\end{array}$ & .0 & .1 & .1 & .0 & .7 & .7 & .0 & .7 & .7 & .0 & 3.2 & 3.2 & -- & -- & - \\
\hline Agricultural irrigation & 5.4 & 8.9 & 14.3 & 3.7 & 9.3 & 13.1 & 2.2 & 19.8 & 22.0 & 5.6 & 40.0 & 45.6 & -- & -- & - \\
\hline Thermoelectric & .0 & 1.6 & 1.6 & .0 & .5 & .5 & .0 & 1.0 & 1.0 & .0 & .0 & .0 & .0 & .0 & .0 \\
\hline Total daily use & 5.4 & 14.8 & 20.2 & 3.7 & 16.0 & 19.8 & 2.2 & 29.4 & 31.6 & 5.6 & 53.7 & 59.3 & -- & -- & $\ldots$ \\
\hline
\end{tabular}

The area in central Osceola County where water quality in the Upper Floridan aquifer is poor to marginal (fig. 42) coincides with an area of low transmissivity in the upper part of the Floridan aquifer system according to Planert and Aucott (1985, p. 28). They reported that the area of greatest potential for well-field development in Osceola County was west of Holopaw. Shaw and Trost (1984a, fig. 75) indicated that the suitability for water-supply development was good in the northwestern and northcentral part of Osceola County, based on transmissivity and water-quality considerations. Suitability for development was shown as moderate in the southwestern part of the county and poor elsewhere in the South Florida Water Management District part of Osceola County. Apparently, the Floridan aquifer system in Osceola County is approximately at equilibrium, except during periods following sustained increases in pumpage. Development has caused recharge to and discharge from the aquifer system to increase. According to Bush and Johnston (1988, p. C74) most discharge from the system in Osceola County probably is diffused upward leakage to the surficial aquifer system and to surface-water bodies. The remainder of discharge is from pumpage, supplied primarily by the diversion of natural outflow from the system and by induced recharge rather than by removal of water from aquifer storage.

Bush and Johnston (1988, p. C75) stated that the response to future development will continue to involve increases in recharge and diversions of natural discharge rather than sustained withdrawals from aquifer storage. The major constraint on future development is potential degradation of water quality rather than lack of quantity. The possible movement of saline water into a well field is an important factor to consider in planning future development. For any well field that may be developed, it would be advantageous to install an observation well network to monitor water-level changes and chloride concentrations in and below the pumped zone.

\section{WATER USE}

The water used in Osceola County includes fresh ground water, fresh surface water, and saline ground water. Fresh ground water is used primarily for public supply, domestic, commercial, and agricultural purposes. Some fresh surface water is used for irrigation and livestock watering. A small amount of nonpotable water, mostly from flowing wells, is used in the eastern part of the county for irrigation. Data on saline-water use in the county is unavailable.

Water use in Osceola County for the standard categories of water use; domestic, commercial and industrial selfsupplied, agricultural, and thermoelectric power generation are listed in table 5. Water used for domestic purposes may be obtained from a public supply or may be self-supplied. Public-supply water use is concentrated in the northern part of the county. Self-supplied domestic water use is scattered throughout the county. Commercial and industrial water use, also concentrated in the more populated northern part of the county, includes self-supplied water used in businesses for production, processing, cooling, retail operations, and processing of agricultural products. Agricultural water use is scattered throughout the county and includes the water used for irrigation and livestock purposes.

Data from historical water-use reports for 1970, 1975, 1980, 1985, and 1987 are listed in table 5. Average daily use is presented by category, subcategory, and water source used. Total average daily water use for each major water-use category is shown in figure 43. Total water use in Osceola County has steadily increased since 1970 , with a sharp increase between 1980 and 1985. Total water use was 59.3 $\mathrm{Mgal} / \mathrm{d}$ in 1985 (Marella, 1988), an increase of $39.1 \mathrm{Mgal} / \mathrm{d}$ from 1970 and an increase of $27.7 \mathrm{Mgal} / \mathrm{d}$ (87 percent) from 1980. Reported ground-water use in 1985 was $53.7 \mathrm{Mgal} / \mathrm{d}$ (92 percent of the supply was from the Floridan aquifer system). Surface-water use was $5.6 \mathrm{Mgal} / \mathrm{d}$. In 1985, 17.6 percent of total water use was domestic, 5.4 percent commercial, and 77 percent agricultural. 


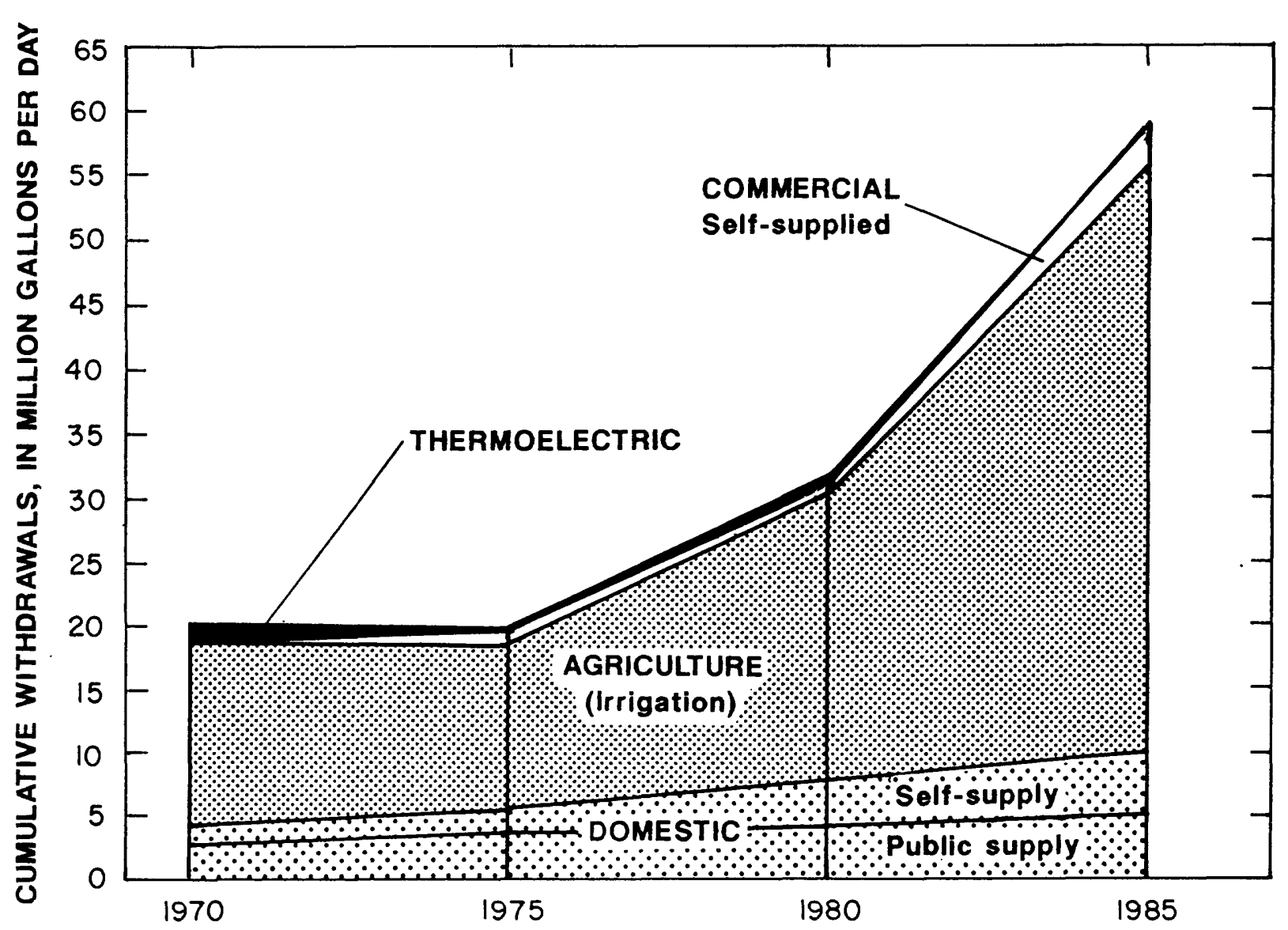

Figure 43. Cumulative water use in Osceola County.

Domestic water use in 1985 was $10.5 \mathrm{Mgal} / \mathrm{d}$ of which $5.7 \mathrm{Mgal} / \mathrm{d}$ was for public supply, an increase of 36 percent from 1980 (table 5). All water used for public-supply was from the Floridan aquifer system. In 1970, 57 percent of the population in Osceola County was served by public supply, the percentage increased to 62 percent in 1987, and 66 percent in 1989. Self-supplied domestic water use increased 28 percent for the period 1970 to 1989 . The largest increase in public supply occurred between 1980 and 1985. However, the largest self-supplied domestic water use increase (106 percent) was between 1975 and 1980. Two percent of the water for domestic self-supplied use was from the Floridan aquifer system. Figure 44, showing annual pumpage by Kissimmee from 1972 to 1988 and St. Cloud from 1977 to 1988 , illustrates the trend of increased public-supply water use. In 1988, pumpage at Kissimmee was $5.8 \mathrm{Mgal} / \mathrm{d}$ and at St. Cloud it was $1.8 \mathrm{Mgal} / \mathrm{d}$.

Commercial water withdrawals in Osceola County for 1985 totaled $3.2 \mathrm{Mgal} / \mathrm{d}$, (all from the Floridan aquifer system) a 357 percent increase in use from 1980 (table 5). This large difference in a category previously stable is most likely explained by a change in accounting techniques. Water used by self-supplied motels, which had been previously classed as domestic water use was counted as commercial water use beginning in 1985. Also, some of the increase in commercial water use may have been because of additional commercial development.
Between 1980 and 1985 agricultural withdrawals, mostly for irrigation, increased 107 percent to $45.6 \mathrm{Mgal} / \mathrm{d}$. Surface-water withdrawals for agricultural use totaled 5.6 $\mathrm{Mgal} / \mathrm{d}$ in 1985, accounting for 12.2 percent of the total agricultural withdrawals. The remainder of the withdrawals was ground water withdrawn from the Floridan.

Prior to 1980 , fresh ground water was the source of water used in thermoelectric power generation at two plants. Between 1980 and 1985, both powerplants converted to the use of public-supply potable water and reclaimed water in the power generation process. This accounts for the large decrease in water withdrawals for this category between 1980 and 1985 (table 5).

The most recent water-use data available for Osceola County is for domestic public supply and self-supplied domestic water use in 1987 . The data show a 32 percent increase in public-supply water use from 1985 to 1987 (5.7-7.5 $\mathrm{Mgal} / \mathrm{d})$ and about a 4 percent reduction $(4.8-4.6 \mathrm{Mgal} / \mathrm{d})$ in self-supplied use for the same period. Domestic water use (includes public-supply and self-supplied) is expected to rise with the predicted rise in population in Osceola County by the year 2010. In 1989, Osceola County had a population of 97,605 and is projected to increase to 179,000 (medium projection) by the year 2010 (Smith and Bayya, 1990). Public-supply water use is projected to increase to 17.6 Mgal/d by 2010 (R.L. Marella, U.S. Geological Survey, written commun., 1991) and, combined with self-supplied, will surpass $20 \mathrm{Mgal} / \mathrm{d}$. 


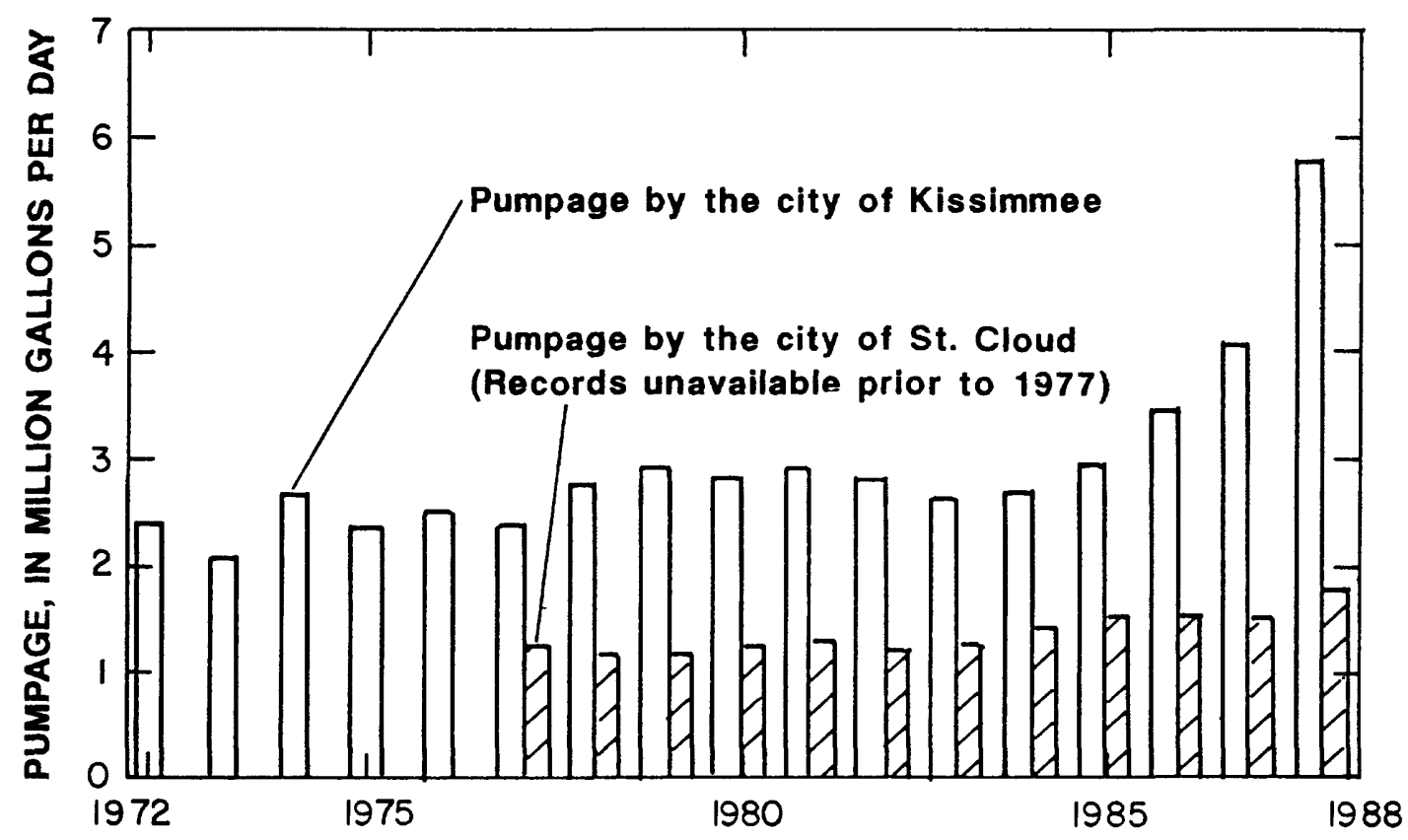

Figure 44. Annual pumpage by the city of Kissimmee, 1972-88, and the city of St. Cloud, 1977-88.

The anticipated population growth in the near future also is expected to cause an increase in commercial water use. Commercial use did not change significantly in the decade 1970 to 1980 , as shown in figure 43 . The large rate of change between 1980 and 1985 was probably caused by use classification changes prior to the 1985 water-use study. Commercial use in the future may increase at a slow rate until industrial development expands into Osceola County, probably from south Orange County. The source of most future commercial water use will probably be from public water supply derived from wells that tap the Floridan aquifer system.

Agriculture water use (mostly irrigation) in Osceola County is expected to continue to increase at a rate similar to that shown for the 1980-85 period (107 percent or 45.6 $\mathrm{Mgal} / \mathrm{d}$ ) until about 1992 when a planned 4,000 acres of citrus is planted. In 1985, 16,270 acres of citrus crop were irrigated and the water use was $35.7 \mathrm{Mgal} / \mathrm{d}$ (R.L. Marella, U.S. Geological Survey, written comm., 1991). If irrigation methods are improved, thereby reducing application rates, the rate of increase in agricultural water use may slow.

Most future water-use needs in Osceola County probably will be met using ground water from the Floridan aquifer system because water from the Floridan aquifer system is readily available in large amounts and is of good quality throughout much of the county, because reservoir sites for surface water are lacking, and because development costs are considerably higher for surface water installations than for well fields. A substantial increase in the use of surface water is not anticipated in the near future.

\section{SUMMARY AND CONCLUSIONS}

The surficial aquifer system and the Floridan aquifer system are the primary sources of ground water used in Osceola County, with about 90 percent of the ground water used in the Osceola County being from the Floridan aquifer system. The two systems are separated by the intermediate confining unit, which is utilized in only a few places for water supply.

The surficial aquifer system underlies the entire county, and consists of unconsolidated deposits of Pleistocene and Holocene age that range in thickness from about 30 to $270 \mathrm{ft}$. The aquifer generally thickens eastward. The most permeable part of the surficial aquifer system generally is within the top $100 \mathrm{ft}$.

The hydraulic properties of the surficial aquifer system vary widely from place to place depending on the lithology and thickness of the unit. An arbitrary value of 1,000 $\left[\left(\mathrm{ft}^{3} / \mathrm{d}\right) / \mathrm{ft}^{2}\right] \mathrm{ft}$ was selected as a transmissivity value for the surficial aquifer system in a digital computer model of an area that includes Osceola County. A range of storage coefficients of 0.05 to 0.2 is considered representative for the aquifer.

Heads in the surficial aquifer system are mostly represented by the water table which may vary substantially in altitude from place to place. Peak levels generally are reached in the summer and minimum levels commonly occur in spring. Fluctuations of the water table and the potentiometric surface of the Upper Floridan aquifer are similar but the magnitude of fluctuation generally is less in the surficial system. 
The surficial aquifer system in Osceola County is recharged mostly by infiltration of rainfall and by some seepage from streams, lakes, and irrigated lands. Discharge from the surficial aquifer is principally from evaporation. Hydrographs of three long-term and several short-term observation wells indicate no significant upward or downward trend in water levels. Therefore, recharge from summer rains generally have been able to replenish the water discharged from the aquifer.

The quality of water in the surficial aquifer system generally meets the State of Florida primary and secondary standards for the most common inorganic constituents. Water in the surficial system generally is a calcium bicarbonate type of dissolved-solids concentrations. Dissolved-solids concentrations generally are less than $100 \mathrm{mg} / \mathrm{L}$ and chloride concentrations generally are less than $50 \mathrm{mg} / \mathrm{L}$. Water from the surficial aquifer system ranges from soft to moderately hard, and is low in mineral content and slightly acidic in $\mathrm{pH}$. High iron concentration is a local water-quality problem.

About 10 percent of the ground water used in Osceola County is from wells that tap the surficial aquifer system. Wells completed in the system commonly yield at least 15 $\mathrm{gal} / \mathrm{min}$ throughout the county but the yields can be as high as $300 \mathrm{gal} / \mathrm{min}$. Because water from the Floridan aquifer system is commonly saline in eastern Osceola County, the surficial aquifer is often tapped there to obtain small to moderate supplies.

The Hawthorn Formation of Miocene age forms the intermediate confining unit--a unit of low permeability that separates the overlying surficial aquifer system from the underlying Floridan aquifer system. The intermediate confining unit varies considerably in thickness, but generally thickens to the south and east in Osceola County from about $40 \mathrm{ft}$ in the northwestern part of the county to about $150 \mathrm{ft}$ in southern part. Reported vertical hydraulic conductivity values for the unit range from $1.5 \times 10^{-2}$ to $7.8 \times 10^{-7} \mathrm{ft} / \mathrm{d}$. Reported leakage coefficients range from about $5 \times 10^{-5}$ per day to about $3 \times 10^{-4}$ per day. The intermediate confining unit is the source of water supply for domestic and livestock uses in the discharge areas of the Floridan aquifer system where high chloride and sulfate concentrations in water of the Floridan restrict its use.

The Floridan aquifer system in Osceola County is mostly limestone and dolomite that ranges in thickness from $2,400 \mathrm{ft}$ (in the northwestern part) to $2,900 \mathrm{ft}$ (in the southeastern part). The hydrology of the Floridan aquifer system is complex and considerable variation in yield and water quality exist in proximate wells of equal depth. The system consists of the Upper Floridan aquifer, the middle semiconfining unit, and the Lower Floridan aquifer. The permeability of the Upper Floridan aquifer generally is higher than that of the Lower Floridan aquifer, but the middle semiconfining unit and the Lower Floridan aquifer may be productive in places.

The Upper Floridan aquifer ranges in thickness from 300 to $350 \mathrm{ft}$. Its top ranges in altitude from sea level to -275 $\mathrm{ft}$, generally slopes to the southeast, and is irregular and paleokarstic. The most productive water-yielding zones in the Upper Floridan are in the Ocala Limestone and in the upper part of the Avon Park Formation.

The middle semiconfining unit in Osceola County is a mostly dense, dolomitic zone of variable thickness and relatively low permeability and porosity, that is near the middle of the Avon Park Formation. Well data indicate the unit often contains water-yielding zones variable in thickness, extent, number, and altitude. The middle semiconfining unit ranges in thickness from 450 to $700 \mathrm{ft}$. Its top ranges in altitude from -300 to $-600 \mathrm{ft}$. Flowmeter data indicate that the first occurring water-bearing zones within the unit are located about 100 to $200 \mathrm{ft}$ below its top.

The Lower Floridan aquifer consists of zones of low and high permeability consisting of limestone, dolomite, and dolomitic limestone that lie between the middle semiconfining unit and the sub-Floridan confining unit. The unit ranges in thickness from 1,400 to $2,100 \mathrm{ft}$. Its base ranges in altitude from $-2,400$ to $-3,100 \mathrm{ft}$. The highly permeable Boulder Zone near the base of the Lower Floridan is reported to be present in the extreme southeastern corner of the county.

Reported transmissivities from tests of three wells that completely penetrate the Upper Floridan aquifer and terminate in the middle semiconfining unit were about 5,600, 8,900 , and $43,000\left[\left(\mathrm{ft}^{3} / \mathrm{d}\right) / \mathrm{ft}^{2}\right] \mathrm{ft}$. Several regional computer model simulations of the Upper Floridan aquifer indicate that transmissivities in most of Osceola County generally are in the range from 65,000 to $250,000\left[\left(\mathrm{ft}^{3} / \mathrm{d}\right) / \mathrm{ft}^{2}\right] \mathrm{ft}$. In the northwestern part of the county, transmissivity values decline to a range of 6,500 to $65,000\left[\left(\mathrm{ft}^{3} / \mathrm{d}\right) / \mathrm{ft}^{2}\right] \mathrm{ft}$. Model simulations indicate a transmissivity of 6,500 to $60,000\left[\left(\mathrm{ft}^{3} / \mathrm{d}\right) / \mathrm{ft}^{2}\right] \mathrm{ft}$ for the Lower Floridan aquifer. A storage coefficient of about $1 \times 10^{-4}$ to $1 \times 10^{-5}$ is estimated for the Upper Floridan aquifer. The range of specific capacities of wells in the Floridan aquifer system is large and shows little areal pattern. Specific capacities of 27 wells that tap the Floridan aquifer system range from 5 to $510(\mathrm{gal} / \mathrm{min}) / \mathrm{ft}$ with a median of 57 $(\mathrm{gal} / \mathrm{min}) / \mathrm{ft}$.

The potentiometric surface of the Upper Floridan aquifer in May, when the aquifer is most stressed, generally ranges in altitude from about $120 \mathrm{ft}$ on the Lake Wales Ridge in northwestern Osceola to about 35 to $40 \mathrm{ft}$ along the eastern county boundary.

Long-term downward trends in water levels due to development are difficult to ascertain because variations in recharge can mask the trend. Water levels in wells tapping the Floridan aquifer system have generally declined 7 to $15 \mathrm{ft}$ from predevelopment (1930's) to 1987. Hydrographs of most wells used to monitor the potentiometric surface of the Upper Floridan aquifer indicate no significant upward or downward trend of water levels from 1979 to 1988.

In the future, heads in the Floridan aquifer system may decline in the Kissimmee-St. Cloud areas of northwestern Osceola County if there are increases in public-supply water use by rapidly expanding commercial, industrial, and 
residential development. However, the potential decline may be offset by reduced irrigation pumpage where urban development replaces irrigated citrus groves.

Water from the Upper Floridan aquifer in most of the county is hard, relatively high in dissolved-solids concentrations $(250-500 \mathrm{mg} / \mathrm{L})$, and has a slightly alkaline $\mathrm{pH}$. Salinity generally increases minimally with depth in the Upper Floridan aquifer, increases variably in the middle semiconfining unit, and probably increases rapidly in the Lower Floridan aquifer. Water from the Upper Floridan commonly is a calcium magnesian bicarbonate type, except for the area of northeastern Osceola County where chloride concentrations exceed $250 \mathrm{mg} / \mathrm{L}$ and the water is a sodium chloride type. Concentrations of chlorides and dissolved solids commonly exceed the State of Florida Secondary Drinking Water Standards in northeastern Osceola County.

Chloride concentrations in water from the Upper Floridan aquifer in Osceola County range from 4 to 1,100 $\mathrm{mg} / \mathrm{L}$. Lowest concentrations are in the recharge area of the Floridan aquifer system in the northwestern corner of the county (less than $50 \mathrm{mg} / \mathrm{L}$ ). Highest concentrations are in the northeastern corner (250-1,100 mg/L). Chloride concentrations in the western half of the county are less than $50 \mathrm{mg} / \mathrm{L}$. Analysis of long-term water-quality data indicate that on a countywide basis, the chloride concentration of water from wells in the Floridan aquifer system have not changed significantly from 1978 to 1988 , and probably not since 1960 .

The Floridan aquifer system commonly yields abundant supplies of water to wells in Osceola County. Large-diameter wells used for public supply and irrigation yield several thou sand gallons of water per minute. About 90 percent of all ground water used in the county is from the Floridan aquifer system. The western half of the county, excluding the northwestern comer, is mapped as a highly favorable area for future ground-water development. The chief constraint on the development of large quantities of water in eastern Osceola County is the possibility of water-quality degradation. The response to future development will likely continue to involve increases in recharge and diversions of natural discharge rather than sustained withdrawals from aquifer storage. The major consideration relating to future development is potential degradation of water quality rather than lack of quantity. Upconing or lateral movement of saline water are important factors to consider in planning future additional development. For any well field that may be developed, it would be advantageous to install an observation well network to monitor water-level changes and chloride concentrations in and below the pumped zone.

Total water use in Osceola County has steadily increased since 1970 with a sharp increase between 1980 and 1985. Total water use was $59.3 \mathrm{Mgal} / \mathrm{d}$ in 1985 , an increase of $39.1 \mathrm{Mgal} / \mathrm{d}$ from 1970 and an increase of $28 \mathrm{Mgal} / \mathrm{d}$ from 1980 (an 87 percent increase since 1970). Reported groundwater use in 1985 was $53.7 \mathrm{Mgal} / \mathrm{d}$ and surface-water use was $5.6 \mathrm{Mgal} / \mathrm{d}$.
Between 1980 to 1985 , agricultural withdrawals, mostly for irrigation, increased 107 percent to $45.6 \mathrm{Mgal} / \mathrm{d}$. Surface-water withdrawals for agricultural use totaled 5.6 $\mathrm{Mgal} / \mathrm{d}$ in 1985 accounting for 12.2 percent of the total agricultural withdrawals. The remainder of the withdrawals was ground water. Agricultural water use in Osceola County is expected to continue to increase in the near future reflecting planned additional agricultural development.

Future water-use needs in Osceola County will probably be met using the Floridan aquifer system as a source, as has been done in the past. A substantial increase in the use of surface water is not anticipated in the near future. If the current development trend continues as predicted by county planners, much of the agricultural land-use areas in the northern part of the county will be replaced by urban areas. There, agricultural water use would be minimal and the amount of water withdrawn and used for public-water supply probably would not exceed the amount previously withdrawn for irrigation.

\section{SELECTED REFERENCES}

Bradner, L.A., 1987, Potentiometric surface of the Upper Floridan aquifer in the St. Johns River Water Management District and vicinity, Florida, September 1987: U.S. Geological Survey Open-File Report 87-688, 1 sheet.

Brown, R.H., 1963, Estimating the transmissibility of an artesian aquifer from the specific capacity of a well, in Bentall, Ray, Methods of determining, permeability, transmissibility and drawdown: U.S. Geological Survey Water-Supply Paper 1536-I, p. 336-338.

Burns, W.S., 1983, Well plugging applications to the inter-aquifer migration of saline groundwater in Lee County, Florida: West Palm Beach, South Florida Water Management District Technical Publication 83-8, 77 p., apps. I-III.

Bush, P.W., and Johnston, R.H., 1988, Ground-water hydraulics, regional flow, and ground-water development of the Floridan aquifer system in Florida and in parts of Georgia, South Carolina, and Alabama: U.S. Geological Survey Professional Paper 1403-C, 80 p.

Campbell, Dean, Munch, D.A., Johnson, Richard, Parker, M.P., Parker, Bruce, Rao, D.V., Marella, Richard, and Albanesi, Edward, 1984, Section III Water administration and regional management, Chapter 13, St. Johns River Water Management District, in Fernald, E.A., and Patton, D.J., eds., Water Resources Atlas of Florida, Tallahassee, Florida State University, p. 158-177.

Cooke, C.W., 1939, Scenery of Florida: Florida Geological Survey Bulletin 17, $118 \mathrm{p}$.

1939b, Geology of Florida: Florida Geological Survey Bulletin 29, $339 \mathrm{p}$.

Durfor, C.N., and Becker, Edith, 1964, Public water supplies of the 100 largest cities in the United States, 1962: U.S. Geological Survey Water-Supply Paper 1812, 364 p.

Florida Department of Environmental Regulation, 1982, Public drinking water systems, in Florida Administrative Code: Tallahassee, chap. 17-22. 
1989, Rules of the Department of Environmental Regulation, public drinking water system, in Florida Administrative Code: Tallahassee, chap. 17-550.

1989, Water-quality standards, in Florida Administrative Code: Tallahassee, chap. 17-3.

Florida Department of State, 1989, Rules of the Florida Department of Environmental Regulation, public drinking water systems, in Florida Administrative Code: Tallahassee, chap. 17-550, .

Franks, B.J., ed., 1982, Principal aquifers in Florida: U.S. Geological Survey Water-Resources Investigations Open-File Report 82-255, 4 sheets.

Franks, B.J., ed., 1987, Principal aquifers in Florida (revised): U.S. Geological Survey Water-Resources Investigations Open-File Report 82-255, 4 sheets.

Frazee, J.M., Jr., 1980, Ground water in Osceola County, Florida: U.S. Geological Survey Water-Resources Investigations 79-1595, 1 sheet.

Gaggiani, N.G., and McPherson, B.F., 1978, Limnological characteristics of Cypress Lake, upper Kissimmee River basin, Florida: U.S. Geological Survey Water-Resources Investigations Open-File Report 77-45, 1 sheet.

Gee and Jenson, 1987, Osceola-Brevard interdistrict water supply preliminary engineering and feasibility report: Consultant's report prepared for the South Florida Water Management District, West Palm Beach, Fla., in files of South Florida Water Management District, 41 p., apps. A-D.

German, E.R., 1986, Summary of hydrologic conditions in the Reedy Creek Improvement District, central Florida: U.S. Geological Survey Water-Resources Investigations 84-4250, $109 \mathrm{p}$.

Goolsby, D.A., and McPherson, B.F., 1978, Limnology of Taylor Creek Impoundment with reference to other water bodies in upper St. Johns River basin, Florida: U.S. Geological Survey Water-Resources Investigations 78-91, 95 p.

Healy, H.G., 1975, Terraces and shorelines of Florida: Florida Bureau of Geology Map Series 71, 1 sheet.

Herr, J.W., and Shaw, J.E., 1989, South Florida Water Management District ambient ground-water quality: West Palm Beach, South Florida Water Management District Technical Publication 89-1, 12 p., 16 supps., apps. 1-16.

Hughes, G.H., and Frazee, J.M., Jr., 1979, Surface-water features in Osceola County and adjacent areas, Florida: U.S. Geological Survey Water-Resources Investigations Open-File Report 79-1289, 1 sheet.

Johnson, R.A., 1986, Shallow stratigraphic core tests on file at the Florida Geological Survey: Florida Bureau of Geology Information Circular no. 103, p. 287-298.

Kohout, F.A., 1965, A hypothesis concerning cyclic flow of salt water related to geothermal heating in the Floridan aquifer: Transactions of the New York Academy of Sciences, ser. II, 28, no. 2, p. 249-271.

Krieger, R.A., Hatchett, J.L., and Poole, J.L., 1957, Preliminary survey of the saline-water resources of the United States: U.S. Geological Survey Water-Supply Paper 1374, 172 p.

Lamonds, A.G., 1975, Chemical characteristics of the lower Kissimmee River, Florida--with emphasis on nitrogen and phosphorus: U.S. Geological Survey Water-Resources Investigations $45-75,132 \mathrm{p}$.
Leach, S.D., 1978, Source, use, and disposition of water in Florida, 1975: U.S. Geological Survey Water-Resources Investigations Report 78-17, $90 \mathrm{p}$.

1983, Source, use, and disposition of water in Florida, 1980: U.S. Geological Survey Water-Resources Investigations Report 82-4090, 337 p.

Lichtler, W.F., 1972, Appraisal of water resources in the east central Florida region: Florida Bureau of Geology Report of Investigations 61, $52 \mathrm{p}$.

Lloyd, J.M., 1985, Annotated bibliography of Florida basement geology and related regional and tectonic studies including an appendix of Florida deep well data: Florida Bureau of Geology Information Circular 98, $72 \mathrm{p}$.

Macneil, F.S., 1949, Pleistocene shorelines in Florida and Georgia: U.S. Geological Survey Professional Paper 221-F, p. 91-107.

Marella, R.L., 1986, Annual water use survey; 1985: Palatka, St. Johns River Water Management District Technical Publication No. SJ 86-5, 117 p.

1988, Water withdrawals, use and trends in Florida, 1985: U.S. Geological Survey Water-Resources Investigations Report 88-4103, 43 p.

1990, Public-supply water use in Florida, 1987: U.S. Geological Survey Open-File Report 90-596, 39 p.

McKee, J.E., and Wolf, H.W., 1963, Water quality criteria (2d ed.): California State Water Quality Control Board Publication 3-A, $548 \mathrm{p}$.

Miller, J.A., 1986, Hydrogeologic framework of the Floridan aquifer system in Florida and parts of Georgia, Alabama, and South Carolina: U.S. Geological Survey Professional Paper 1403-B, $91 \mathrm{p}$.

National Oceanic and Atmospheric Administration, Climatological data, Florida annuai summaries.

Parker, G.G., Ferguson, G.E., Love, S.K., and others, 1955, Water resources of southeastem Florida: U.S. Geological Survey Water-Supply Paper 1255, 965 p.

Phelps, G.G., 1982, Hydrology of Lake Tohopekaliga, Osceola County, Florida: U.S. Geological Survey Water-Resources Investigations Open-File Report 81-536, 2 sheets.

1984, Recharge and discharge areas of the Floridan aquifer in the St. Johns River Water Management District and vicinity, Florida: U.S. Geological Survey Water-Resources Investigations Report 82-4058, 1 sheet.

Planert, Michael, and Aucott, W.R., 1985, Water-supply potential of the Floridan aquifer in Osceola, eastern Orange, and southwestern Brevard Counties, Florida: U.S. Geological Survey Water-Resources Investigations Report 84-4135, $69 \mathrm{p}$.

Post, Buckley, Schuh, and Jernigan, Inc., 1987, in cooperation with Geraghty and Miller, Inc., Eastern Osceola County exploratory test hole number 1, Project Number 15-060.12, Consultant's report prepared for the South Brevard Water Authority, Melbourne, Fla., in files of U.S. Geological Survey, Altamonte Springs, Fla., 9 p., apps. 1-3.

Pride, R.W., 1973, Estimated use of water in Florida, 1970: Florida Bureau of Geology Information Circular no. 83, 31 p.

Purdum, E.D., and Anderson, J.R., Jr., project directors, 1988, Florida County atlas and municipal facts book: Tallahassee, Fla., Institute of Science and Public Affairs, Florida State University, $145 \mathrm{p}$. 
Putnam, A.L., 1975, Summary of hydrologic conditions and effects of Walt Disney World development in the Reedy Creek Improvement District, 1966-1973: Florida Bureau of Geology Report of Investigations 79, 115 p.

Reese, D.E., Belles, R.B., and Brown, M.P., 1984, Hydrogeologic data collected from the Kissimmee Planning Area, South Florida Water Management District: West Palm Beach, South Florida Water Management District Technical Publication 84-2, 191 p.

St. Johns River Water Management District, 1989, Ground-water quality reconnaissance of the Bull Creek Wildlife Management area Osceola County, Florida: Unpublished report in files of the St. Johns River Water Management District, Palatka, Fla., 15 p., apps. A-B.

Schiffer, D.M., 1986, Hydrology and water quality of east Lake Tohopekaliga, Osceola County, Florida: U.S. Geological Survey Water-Resources Investigations Report 86-4081, 1 sheet.

Schiner, G.R., 1987, Potentiometric surface of the Upper Floridan aquifer in the St. Johns River Water Management District and vicinity, Florida, May 1987: U.S. Geological Survey Open-File Report 87-464, 1 sheet.

Schiner, G.R., and German, E.R., 1983, Effects of recharge from drainage wells on quality of water in the Floridan aquifer in the Orlando area, central Florida: U.S. Geological Survey Water-Resources Investigations Report 82-4094, 124 p.

Schiner, G.R., and Hayes, E.C., 1981, Potentiometric surface map of the Floridan aquifer in the St. Johns River Water Management District and vicinity, Florida, May 1981: U.S. Geological Survey Open-File Report 81-1052, 1 sheet.

Schiner, G.R., Laughlin, C.P., and Toth, D.J., 1988, Geohydrology of Indian River County, Florida: U.S. Geological Survey Water-Resources Investigations Report 88-4073, 110 p.
Shaw, J.E., and Trost, S.M., 1984a, Hydrogeology of the Kissimmee Planning Area, South Florida Water Management District, pt. 1, Text: West Palm Beach, South Florida Water Management District Technical Publication 84-1, 235 p. 1984b, Hydrogeology of the Kissimmee Planning Area, South Florida Water Management District, pt. 2, Appendices: West Palm Beach, South Florida Water Management District Technical Publication 84-1, 251 p., apps. I-VI.

Smith, S.K., and Bayya, Ravi, 1990, Projections of Floridan population by county 1989-2020: Gainesville, University of Florida Bureau of Economic and Business Research, Population Program, v. 23, no. 2, bull. no. 92, 8 p.

Southeastern Geological Society Ad Hoc Committee on Florida Hydrostratigraphic Unit Definition, compiler, 1986, Hydrogeological units of Florida: Florida Bureau of Geology Special Publication no. 28, 9 p.

Sprinkle, C.L., 1982, Chloride concentration in water from the upper permeable zone of the Tertiary limestone aquifer system, southeastern United States: U.S. Geological Survey Water-Resources Investigations Open-File Report 81-1103, 1 sheet.

Stringfield, V.T., 1966, Artesian water in Tertiary limestone in the southeastern States: U.S. Geological Survey Professional Paper 517, $226 \mathrm{p}$.

Tibbals, C.H., 1981, Computer simulation of the steady-state flow system of the Tertiary limestone (Floridan) aquifer system in east-central Florida: U.S. Geological Survey Water-Resources Investigations Open-File Report 81-681, 31 p., 9 sheets.

1990, Hydrology of the Floridan aquifer system in east-central Florida: U.S. Geological Survey Professional Paper 1403-E, 98 p.

White, W.A., 1970, The geomorphology of the Florida Peninsula: Florida Bureau of Geology Bulletin 51, 164 p. 


\section{APPENDIX I}


Appendix I. Well data in files of the U.S. Geological Survey used for analysis $[--$, no data]

\begin{tabular}{|c|c|c|c|c|c|c|c|c|c|}
\hline $\begin{array}{l}\text { Well } \\
\text { No. }\end{array}$ & $\begin{array}{c}\text { Site } \\
\text { identification } \\
\text { No. }\end{array}$ & $\begin{array}{c}\text { Altitude } \\
\text { of land } \\
\text { surface } \\
\text { (feet) }\end{array}$ & $\begin{array}{c}\text { Bottom } \\
\text { of } \\
\text { casing } \\
\text { (feet) }\end{array}$ & $\begin{array}{c}\text { Depth } \\
\text { of } \\
\text { well } \\
\text { (feet) }\end{array}$ & $\begin{array}{l}\text { Well } \\
\text { No. }\end{array}$ & $\begin{array}{c}\text { Site } \\
\text { identification } \\
\text { No. }\end{array}$ & $\begin{array}{c}\text { Altitude } \\
\text { of land } \\
\text { surface } \\
\text { (feet) }\end{array}$ & $\begin{array}{l}\text { Bottom } \\
\text { of } \\
\text { casing } \\
\text { (feet) }\end{array}$ & $\begin{array}{c}\text { Depth } \\
\text { of } \\
\text { well } \\
\text { (feet) }\end{array}$ \\
\hline 1 & 273740080535101 & 70 & -- & -- & 56 & 275826080554701 & 55 & -- & 500 \\
\hline 2 & 273740080551201 & 65.5 & 260 & 973 & 57 & 275838080521101 & 36 & -- & -- \\
\hline 3 & 273929081080601 & 51 & 260 & 1,000 & 58 & 275852081030501 & 75 & 242 & 405 \\
\hline 4 & 274032081012701 & 69 & -- & 9 & 59 & 275901081121501 & 67 & 258 & 600 \\
\hline 5 & 274047080513701 & 57 & 140 & 305 & 60 & 275925080513001 & 27.5 & -- & -- \\
\hline 6 & 274058081074001 & 55 & -- & 100 & 61 & 275936080521401 & 35 & -- & -- \\
\hline 7 & 274152080530101 & 62 & 326 & 680 & 62 & 275957080523401 & 37 & -- & 230 \\
\hline 8 & 274152080540201 & 62 & -- & -- & 63 & 280029081113301 & 69 & -- & 8 \\
\hline 9 & 274153080540301 & 62 & -- & -- & 64 & 280033081015801 & 67 & -- & 800 \\
\hline 10 & 274156080541001 & 60 & 67 & 70 & 65 & 280033081015802 & 70 & -- & 130 \\
\hline 11 & 274156081062401 & 61 & -- & 200 & 66 & 280054081103901 & 77 & -- & 500 \\
\hline 12 & 274158080541701 & 67 & -- & -- & 67 & 280100080501501 & 20 & -- & -- \\
\hline 13 & 274159080541902 & 67 & -- & 485 & 68 & 280153081274101 & 55 & 178 & 411 \\
\hline 14 & 274204080542901 & 66 & -- & 100 & 69 & 280202081024101 & 70 & -- & 520 \\
\hline 15 & 274258080542801 & 72 & -- & 108 & 70 & 280229081325201 & 94 & 137 & 453 \\
\hline 16 & 274307080582401 & 71 & 218 & 767 & 71 & 280229080565501 & 61 & 202 & 329 \\
\hline 17 & 274500081040001 & 67 & -- & -- & 72 & 280247080521901 & 27 & -- & -- \\
\hline 18 & 274509081042901 & 68 & -- & 7 & 73 & 280326080493201 & 20 & -- & -- \\
\hline 19 & 274512080540701 & 59 & -- & -- & 74 & 280343080510001 & 20 & -- & -- \\
\hline 20 & 274553081115601 & 55.5 & 231 & 850 & 75 & 280344080533201 & 43 & -- & -- \\
\hline 21 & 274646081074801 & 62 & 16 & 23 & 76 & 280404080535701 & 40 & 186 & 610 \\
\hline 22 & 274746081202201 & 100.5 & -- & -- & 77 & 280442081153901 & 60 & -- & 64 \\
\hline 23 & 274806081114301 & 50 & 150 & 400 & 78 & 280443080503201 & 20 & -- & 295 \\
\hline 24 & 274806081115501 & 55 & 172 & 880 & 79 & 280448080531601 & 28.5 & -- & -- \\
\hline 25 & 274815081130301 & 55 & 185 & 300 & 80 & 280448080532201 & 25 & -- & -- \\
\hline 26 & 274827081112302 & 57 & -- & - & 81 & 280501080523701 & 27 & 325 & 375 \\
\hline 27 & 274829081111601 & 57 & -- & -- & 82 & 280526080543001 & 44 & 272 & 660 \\
\hline 28 & 274856080594401 & 72 & 215 & 877 & 83 & 280531081043101 & 77 & -- & -- \\
\hline 29 & 274916080520701 & 52 & 120 & 260 & 84 & 280532080514501 & 25 & -- & -- \\
\hline 30 & 274927080590801 & 71 & -- & 400 & 85 & 280533081041001 & 72 & 354 & 891 \\
\hline 31 & 274942081202701 & 74 & 102 & 800 & 86 & 280534081070201 & 82 & -- & 610 \\
\hline 32 & 274947080584001 & 74 & -- & 90 & 87 & 280535081075901 & 82 & -- & 580 \\
\hline 33 & 274949080503901 & 37 & -- & -- & 88 & 280537081063601 & 82 & -- & -- \\
\hline 34 & 275045080494601 & 28 & -- & 284 & 89 & 280537081163001 & 68 & 256 & 469 \\
\hline 35 & 275047080524301 & 52 & 229 & 605 & 90 & 280539081060201 & 80 & -- & 890 \\
\hline 36 & 275156080581801 & 75 & -- & 690 & 91 & 280539081162801 & 68 & -- & 315 \\
\hline 37 & 275222081030701 & 63 & 243 & 310 & 92 & 280539081163701 & 68 & -- & -- \\
\hline 38 & 275222081030702 & 59 & -- & 28 & 93 & 280542081163301 & 68 & -- & -- \\
\hline 39 & 275225081000201 & 72 & -- & -- & 94 & 280558081314801 & 74 & 149 & 399 \\
\hline 40 & 275226081030601 & 60 & -- & -- & 95 & 280602080535401 & 47 & -- & 100 \\
\hline 41 & 275233080595101 & 72 & 220 & 516 & 96 & 280619080542601 & 49 & 18 & 18 \\
\hline 42 & 275235081000201 & 71 & -- & 500 & 97 & 280619080542602 & 48 & 14 & 16 \\
\hline 43 & 275248080514101 & 46 & -- & -- & 98 & 280620080542601 & 46 & -- & -- \\
\hline 44 & 275429081071901 & 67 & -- & 318 & 99 & 280632081050101 & 77 & 344 & 718 \\
\hline 45 & 275508080510701 & 29 & -- & 272 & 100 & 280634081372301 & 178 & -- & 803 \\
\hline 46 & 275519080595201 & 70 & -- & -- & 101 & 280637080502101 & 19 & -- & -- \\
\hline 47 & 275530081022401 & 65 & 448 & 1,040 & 102 & 280655080501901 & 21 & -- & 620 \\
\hline 48 & 275609081132001 & 59 & 288 & 400 & 103 & 280656081321001 & 90 & 210 & 268 \\
\hline 49 & 275613080594501 & 65 & 190 & 263 & 104 & 280659081002801 & 40 & -- & 1,470 \\
\hline 50 & 275622081252301 & 60 & -- & 575 & 105 & 280709081052201 & 82 & -- & -- \\
\hline 51 & 275629080504901 & 27 & - & 228 & 106 & 280739080592201 & 57 & -- & -- \\
\hline 52 & 275634081102701 & 68 & 249 & 869 & 107 & 280746080524601 & 27 & -- & 545 \\
\hline 53 & 275634081211801 & 56.5 & 226 & 560 & 108 & 280802080580301 & 61 & -- & 297 \\
\hline 54 & 275738080520801 & 36 & -- & -- & 109 & 280811080514401 & 25 & -- & 432 \\
\hline 55 & 275740081030701 & 72 & - & -- & 110 & 280813081043701 & 75 & - & 269 \\
\hline
\end{tabular}


Appendix I. Well data in files of the U.S. Geological Survey used for analysis-Continued $[--$, no data]

\begin{tabular}{|c|c|c|c|c|c|c|c|c|c|}
\hline $\begin{array}{l}\text { Well } \\
\text { No. }\end{array}$ & $\begin{array}{c}\text { Site } \\
\text { identification } \\
\text { No. }\end{array}$ & $\begin{array}{l}\text { Altitude } \\
\text { of land } \\
\text { surface } \\
\text { (feet) }\end{array}$ & $\begin{array}{l}\text { Bottom } \\
\text { of } \\
\text { casing } \\
\text { (feet) }\end{array}$ & $\begin{array}{l}\text { Depth } \\
\text { of } \\
\text { well } \\
\text { (feet) }\end{array}$ & $\begin{array}{l}\text { Well } \\
\text { No. }\end{array}$ & $\begin{array}{c}\text { Site } \\
\text { identification } \\
\text { No. }\end{array}$ & $\begin{array}{l}\text { Altitude } \\
\text { of land } \\
\text { surface } \\
\text { (feet) }\end{array}$ & $\begin{array}{l}\text { Bottom } \\
\text { of } \\
\text { casing } \\
\text { (feet) }\end{array}$ & $\begin{array}{l}\text { Depth } \\
\text { of } \\
\text { well } \\
\text { (feet) }\end{array}$ \\
\hline 111 & 280820081213901 & 60 & 176 & 318 & 161 & 281559081260701 & 60 & -- & 200 \\
\hline 112 & 280823081210301 & 60.5 & 160 & 980 & 162 & 281614080514401 & 18 & -- & 138 \\
\hline 113 & 280826081031801 & 70 & 322 & 1,097 & 163 & 281630080544203 & 38.5 & 201 & 445 \\
\hline 114 & 280827081045601 & 75 & 298 & 560 & 164 & 281630080591001 & 60 & 245 & -- \\
\hline 115 & 280829080574001 & 59.5 & 220 & 425 & 165 & 281630081024401 & 77 & 288 & -- \\
\hline 116 & 280837080514401 & 24 & -- & -- & 166 & 281632080515001 & 20 & -- & 253 \\
\hline 117 & 280840081043701 & 75 & -- & 600 & 167 & 281634080542201 & 32 & - & -- \\
\hline 118 & 280905081270101 & 63.5 & 134 & 398 & 168 & 281653081221101 & 72 & -- & 700 \\
\hline 119 & 280928080532001 & 30 & -- & 610 & 169 & 281714081093001 & 65 & 389 & 740 \\
\hline 120 & 280928080533001 & 32 & -- & 610 & 170 & 281719081134001 & 77 & 239 & 474 \\
\hline 121 & 280934080495601 & 19 & - & -. & 171 & 281721081264801 & 80 & 140 & 398 \\
\hline 122 & 280950081161501 & 69 & -- & 65 & 172 & 281722080543001 & 31.5 & 13 & 19 \\
\hline 123 & 280954081050001 & 77 & 328 & 463 & 173 & 281722080543002 & 32 & 14 & 16 \\
\hline 124 & 280954081161101 & 70 & -- & 246 & 174 & 281723081242301 & 59.5 & -- & 457 \\
\hline 125 & 281006081162601 & 72 & -- & 500 & 175 & 281724081265301 & 72 & - & 8 \\
\hline 126 & 281016080515401 & 19 & -- & -- & 176 & 281725081242501 & 57 & -- & 400 \\
\hline 127 & 281037081075101 & 72 & 282 & 457 & 177 & 281726081262301 & 76 & 140 & 175 \\
\hline 128 & 281058081364201 & 113 & 81 & 180 & 178 & 281730081091401 & 65 & -- & -- \\
\hline 129 & 281105080541401 & 47 & -- & -- & 179 & 281802081351601 & 110 & 85 & 450 \\
\hline 130 & 281116081024101 & 75 & 210 & 513 & 180 & 281802081352501 & 57 & 80 & 150 \\
\hline 131 & 281126080525701 & 22 & -- & 602 & 181 & 281816080535401 & 27 & -- & 602 \\
\hline 132 & 281141081094101 & 79 & 14 & 16 & 182 & 281820080540501 & 29 & 108 & 603 \\
\hline 133 & 281146081211701 & 77 & 302 & 582 & 183 & 281919080533301 & 20 & 163 & 344 \\
\hline 134 & 281147081120601 & 72.5 & -- & -- & 184 & 281922081244301 & 81 & 236 & 375 \\
\hline 135 & 281159081142801 & 75 & 320 & 622 & 185 & 281931081280301 & 80 & -- & 378 \\
\hline 136 & 281239080535601 & 30 & 121 & 590 & 186 & 281937081245901 & 88 & 283 & 1,195 \\
\hline 137 & 281246080532301 & 26.5 & -- & 588 & 187 & 281937081250101 & 87.5 & 278 & 458 \\
\hline 138 & 281251080530701 & 24 & 112 & 381 & 188 & 281944081344301 & 80 & -- & -- \\
\hline 139 & 281251080532301 & -. & -- & -- & 189 & 281949080531201 & 19 & 172 & 309 \\
\hline 140 & 281325081004101 & 73 & - & 405 & 190 & 281955081370701 & 99 & 99 & 300 \\
\hline 141 & 281341081281301 & 77 & -- & -- & 191 & 282000081344801 & 78 & 72 & 150 \\
\hline 142 & 281354080563301 & 52.5 & 173 & 373 & 192 & 282009080553101 & 28 & -- & - \\
\hline 143 & 281356081290901 & 71.5 & -- & 360 & 193 & 282040081240901 & 85 & -- & 260 \\
\hline 144 & 281411081113001 & 70 & -- & 439 & 194 & 282050081140201 & 65 & 220 & 470 \\
\hline 145 & 281412081113201 & 70 & -- & -- & 195 & 282051081133201 & 62 & 373 & 470 \\
\hline 146 & 281429081290501 & 77 & -- & -- & 196 & 282051081183401 & 75 & 199 & 400 \\
\hline 147 & 281440081150901 & 75 & 320 & 538 & 197 & 282052080553101 & 27 & 108 & 300 \\
\hline 148 & 281443081140501 & 75 & -- & 400 & 198 & 282051081183401 & 75 & 199 & 400 \\
\hline 149 & 281456081161101 & 75 & 224 & 496 & 199 & 282141081241701 & 85 & 317 & 435 \\
\hline 150 & 281456081171701 & 75 & 481 & 614 & 200 & 282158080505701 & 14 & - & - \\
\hline 151 & 281456081171801 & 74 & -- & -- & 201 & 282202081384601 & 117 & 103 & 318 \\
\hline 152 & 281456081171901 & 74 & -. & -- & 202 & 282207080521801 & 15 & -- & -- \\
\hline 153 & 281457081172201 & 78 & 382 & 692 & 203 & 282209081180901 & 80 & -- & 186 \\
\hline 154 & 281505080515801 & 17 & -- & -- & 204 & 282241081112801 & 70 & 240 & 480 \\
\hline \multirow[t]{2}{*}{155} & 281508081194701 & 60 & -- & 418 & 205 & 282241081302401 & 113.5 & 203 & 500 \\
\hline & & & & & 206 & 282247081364801 & 115 & 166 & 380 \\
\hline 156 & 281508081194702 & 60 & 68 & 78 & & & & & \\
\hline 157 & 281511081393101 & 180 & 358 & 447 & & & & & \\
\hline 158 & 281532080544401 & 41 & -- & 382 & & & & & \\
\hline 159 & 281532081345001 & 104.5 & 85 & 247 & & & & & \\
\hline 160 & 281536081324801 & 72 & 63 & 261 & & & & & \\
\hline
\end{tabular}


APPENDIX II 
Appendix II. Well data in files of the Florida Geological Survey used for analysis

\begin{tabular}{|c|c|c|c|c|c|c|c|}
\hline $\begin{array}{c}\text { Site } \\
\text { identification } \\
\text { No. }\end{array}$ & $\begin{array}{l}\text { Latitude } \\
\text { and } \\
\text { longitude }\end{array}$ & $\begin{array}{l}\text { Altitude } \\
\text { of land } \\
\text { surface } \\
\text { (feet) }\end{array}$ & $\begin{array}{l}\text { Depth } \\
\text { of } \\
\text { well } \\
\text { (feet) }\end{array}$ & $\begin{array}{c}\text { Site } \\
\text { identification } \\
\text { No. }\end{array}$ & $\begin{array}{l}\text { Latitude } \\
\text { and } \\
\text { longitude }\end{array}$ & $\begin{array}{l}\text { Altitude } \\
\text { of land } \\
\text { surface } \\
\text { (feet) }\end{array}$ & $\begin{array}{l}\text { Depth } \\
\text { of } \\
\text { well } \\
\text { (feet) }\end{array}$ \\
\hline W-1510 & 2818400805455 & 43 & 270 & W-9151 & 2748400810830 & 60 & 610 \\
\hline W-1749 & 2816280805405 & 38 & 1,460 & W-9156 & 2744090810628 & 62 & 690 \\
\hline W-1882 & 2815000811430 & 77 & 470 & W-9349 & 2751150810515 & 64 & 300 \\
\hline W-3386 & 2814480811752 & 74 & 692 & W-10537 & 2819300812758 & 80 & 330 \\
\hline W-3743 & 2806380805438 & 47 & 350 & W-10586 & 2817550811442 & 65 & 375 \\
\hline W-3783 & 2750430804941 & 28 & 948 & W-10587 & 2819280811405 & 65 & 259 \\
\hline W-5121 & 2816280812422 & 61 & 412 & W-10696 & 2816000812645 & 65 & 336 \\
\hline W-5236 & 2818180812408 & 66 & 340 & W-10899 & 2820180813458 & 80 & 300 \\
\hline W-5803 & 2813200811100 & 83 & 645 & W-11040 & 2815120812750 & 69 & 255 \\
\hline W-5869 & 2815530811912 & 71 & 630 & W-11300 & 2820300813830 & 125 & 420 \\
\hline W-7658 & 2817040813523 & 95 & 54 & W-11366 & 2759200811222 & 67 & 540 \\
\hline W-9116 & 2809010805415 & 50 & 290 & W-11369 & 2806550812550 & 65 & 620 \\
\hline W-9118 & 2749150805428 & 62 & 620 & W-11415 & 2815050812955 & 70 & 400 \\
\hline W-9119 & 2747320810103 & 72 & 660 & W-11416 & 2813200812900 & 71 & 380 \\
\hline W-9120 & 2749280810048 & 75 & 660 & W-11420 & 2809530812652 & 70 & 400 \\
\hline W-9122 & 2748000805640 & 64 & 620 & W-11478 & 2820180813558 & ${ }^{1} 110$ & 360 \\
\hline W-9124 & 2747330805805 & 69 & 320 & W-11517 & 2819190812946 & 68 & 400 \\
\hline W-9125 & 2749000805735 & 72 & 500 & W-11558 & 2820190813756 & 100 & 360 \\
\hline W-9127 & 2739520805806 & 60 & 697 & W-11685 & 2802000810238 & 67 & 520 \\
\hline W-9128 & 2742180805530 & 65 & 400 & W-11913 & 2820220813057 & 73 & 385 \\
\hline W-9129 & 2743100805802 & 70 & 667 & W-11954 & 2805300810410 & 75 & 380 \\
\hline W-9130 & 2743370810058 & 68 & 634 & W-12356 & 2818480812758 & 75 & 430 \\
\hline W-9131 & 2744550810430 & 64 & 626 & W-12883 & 2820030813225 & 91 & 305 \\
\hline W-9132 & 2742460810600 & 64 & 680 & W-13482 & 2816270805315 & 27 & 363 \\
\hline W-9133 & 2740350810802 & 52 & 600 & W-13489 & 2815320805444 & 41 & 382 \\
\hline W-9134 & 2741220810136 & 70 & 610 & W-13496 & 2817050805432 & 35 & 379 \\
\hline W-9135 & 2742450805505 & 70 & 490 & W-13516 & 2816250805340 & 30 & 394 \\
\hline W-9137 & 2741250810635 & 57 & 650 & W-13533 & 2816200805440 & 41 & 452 \\
\hline W-9138 & 2740080810508 & 58 & 600 & W-13534 & 2816520805947 & 65 & 392 \\
\hline W-9139 & 2740030810337 & 57 & 615 & W-13547 & 2812300811412 & ${ }^{1} 75$ & 550 \\
\hline W-9140 & 2740020805412 & 70 & 350 & W-13551 & 2812130805814 & 45 & 490 \\
\hline W-9141 & 2744350810743 & 67 & 710 & W-13676 & 2816370810446 & 80 & 342 \\
\hline W-9143 & 2738520810128 & 56 & 410 & W-13893 & 2810000811500 & 75 & 574 \\
\hline W-9144 & 2742170810728 & 57 & 640 & W-13942 & 2756370805934 & 55 & 432 \\
\hline W-9145 & 2743590810329 & 68 & 510 & W-13957 & 2758090805217 & 37 & 232 \\
\hline W-9147 & 2752350810220 & 69 & 710 & W-14032 & 2814200811500 & 75 & 416 \\
\hline W-9149 & 2749370810530 & 65 & 660 & W-14070 & 2811400811415 & 70 & 630 \\
\hline W-9150 & 2749050810728 & 63 & 490 & W-14501 & 2803400805330 & 45 & 610 \\
\hline
\end{tabular}

${ }^{1}$ Estimated. 